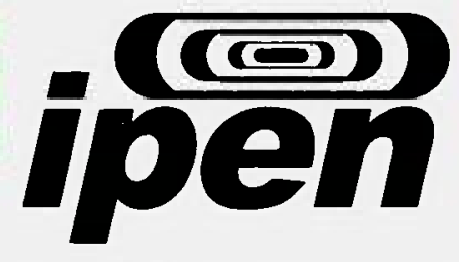

AUTARQUIA ASSOCIADA À UNIVERSIDADE DE SÃO PAULO

\title{
CONTAMINAÇÃO DE SOLO POR METAIS TÓXICOS PROVENIENTES DO DESCARTE INADEQUADO DE PILHAS ZINCO-CARBONO DE USO DOMÉSTICO
}

\author{
VANESSA SANTOS OLIVEIRA GAZANO
}

Dissertação apresentada como parte dos requisitos para obtenção do Grau de Mestre em Ciências na Área de Tecnologia Nuclear - Materiais.

Orientadora:

Dra. Marlene Sotto-Mayor Flues

São Paulo 
INSTITUTO DE PESQUISAS ENERGÉTICAS E NUCLEARES

Autarquia associada à Universidade de São Paulo

CONTAMINAÇÃO DE SOLO POR METAIS TÓXICOS PROVENIENTES DO DESCARTE INADEQUADO DE PILHAS ZINCO-CARBONO DE USO DOMÉSTICO

VANESSA SANTOS OLIVEIRA GAZANO

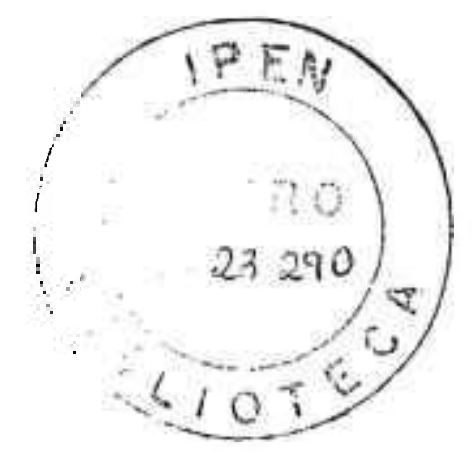

Dissertação apresentada como parte dos requisitos para obtenção do Grau de Mestre em Ciências na Área de Tecnologia Nuclear - Materiais

Orientador:

Dra. Marlene Sotto- Mayor Flues

SÃO PAULO 
A Rener e Renzo Gazano, com carinho. 


\section{AGRADECIMENTOS}

Agradeço,

a Dr. Marlene Flues pela orientação e oportunidade

ao Dr. Joel Sígolo, pelo apoio, ensinamentos e auxilio em todas as etapas desta dissertação.

ao Dr. Raphael Hypolito, pelo auxilio, pelas conversas, e ser por um dos melhores professores que eu tive a oportunidade de conhecer,

a Dra. Yara Maria Carneiro Camargo que auxiliou durante todo o periodo, e ajudou na finalização dos textos,

a Dra. Elisabeth Oliveira pelas análises das amostras

a Dra. Marycel Contrim

Ao Técnico Samuel Egidio (Samuca) que ajudou na coleta e preparação das amostras,

aos amigos da pós-graduação Kleber Cavaça Campos, Sibele Ezaki, Demétrios Agourakis, Gabriel Perez, Valéria Guimarães, Cyntia Pinheiro e Celi Zanon.

aos amigos da graduação em Geologia Fábio Luís (Suíno), Michele Torres Fernandez, Gabriella Tálamo e Fabiana Cruz,

ao Instituto de Pesquisas Energéticas e Nucleares - IPEN e Instituto de Geociências, pela oportunidade de realizar essa pesquisa, e utilização dos laboratórios

E por fim aos meus pais, ao meus irmãos e ao Rener pelo incentivo aos estudos, compreensão, amor e carinho em todos os momentos. 
"Tivesse eu os tecidos adornados do céu, ornamentados com luzes d'ouro e prata..."

"Os tecidos azuis, indistintos e escuros da noite, a luz e os meios-tons, espalhálos-ia a teus pés..."

Mas eu, sendo pobre, tenho apenas meus sonhos. Espalhei-os, então, a teus pés; pisa com delicadeza, pois caminhas sobre meus sonhos." 
"Tivesse eu os tecidos adornados do céu, ornamentados com luzes d'ouro e prata..."

"Os tecidos azuis, indistintos e escuros da noite, a luz e os meios-tons, espalhálos-ia a teus pés..."

Mas eu, sendo pobre, tenho apenas meus sonhos. Espalhei-os, então, a teus pés; pisa com delicadeza, pois caminhas sobre meus sonhos." 


\title{
CONTAMINAÇÃO DE SOLO POR METAIS TÓXICOS PROVENIENTES DO DESCARTE INADEQUADO DE PILHAS ZINCO-CARBONO DE USO DOMÉSTICO
}

\section{Vanessa Santos Oliveira Gazano}

\begin{abstract}
RESUMO
O presente trabalho determinou a concentração dos metais zinco, manganês, cádmio, chumbo, niquel, cobre e cromo no efluente e solo de quatro colunas de latossolo indeformadas. Duas colunas foram contaminadas por pilhas do tipo zinco-carbono e duas colunas foram utilizadas como referência, além de pilhas isoladas, foram todas lixiviadas por uma solução "água de chuva" $\left(\mathrm{HNO}_{3}+\right.$ $\mathrm{H}_{2} \mathrm{SO}_{4}, \mathrm{pH} 4,0$ ). Os metais no efluente e no solo foram determinados pela técnica de ICP-OES. A avaliação do efluente e do solo das colunas contaminadas pelas pilhas mostrou um incremento das concentrações dos metais, principalmente de zinco, manganês e chumbo. A seqüência das massas acumuladas dos metais no efluente e no solo da coluna contaminada apresentaram uma seqüência semelhante a da lixiviação isolada da pilha $(\mathrm{Zn}>\mathrm{Mn}>\mathrm{Pb}>\mathrm{Cr}>\mathrm{Cu}>\mathrm{Ni}>\mathrm{Cd}$ ), confirmando a influência da pilha nas concentrações dos metais no efluente e solo das colunas. Observou-se também que a contaminação de $\mathrm{Zn}$ e $\mathrm{Mn}$ tende a migrar da camada superior da coluna de solo para as camadas inferiores. O estudo mostrou que as pilhas podem causar uma contaminação significativa do solo para os metais $\mathrm{Zn}, \mathrm{Mn}$ e $\mathrm{Pb}$ e possivelmente também para $\mathrm{Cd}$. Esta contaminação do solo poderia vir a causar uma contaminação da água subterrânea para os metais $\mathrm{Zn}, \mathrm{Mn}$ e $\mathrm{Pb}$, dependo das caracteristicas do perfil do solo.
\end{abstract}




\title{
SOIL CONTAMINATION OF TOXIC METALS FROM ZINC CARBON BATTERIES INADEQUATE DISPOSAL
}

\author{
Vanessa Santos Oliveira Gazano
}

\begin{abstract}
The aim of the present study was to determine the concentration of $\mathrm{Zn}, \mathrm{Mn}$, $\mathrm{Pb}, \mathrm{Cd}, \mathrm{Cu}, \mathrm{Cr}$, and $\mathrm{Ni}$ in an oxisol column contaminated with zinc-carbon batteries. Two control and two contaminated columns, and batteries alone were leached for a periods of six months and one year with aqueous solution of $\mathrm{HNO}_{3}$ and $\mathrm{H}_{2} \mathrm{SO} 4(1: 1, \mathrm{pH} \mathrm{4,0)}$ to simulate rainwater. The metal concentrations in effluent and soil were measured by means of ICP.OES technique. Results from the contaminated column showed enhanced concentrations in both effluent and soil (mainly zinc, manganese and lead). In addition, the total amount of metals in effluent and soil showed similar sequence order as observed for batteries alone $(\mathrm{Zn}>\mathrm{Mn}>\mathrm{Pb}>\mathrm{Cr}>\mathrm{Cu}>\mathrm{Ni}>\mathrm{Cd}$ ) indicating that batteries can be considered the main source of contamination. We also observed migration of $\mathrm{Zn}$ and $\mathrm{Mn}$ from the top to the lower layers of the soil columns. The study gives further evidence that batteries can significantly contaminate the soil with metals like $\mathrm{Zn}, \mathrm{Mn}$ and $\mathrm{Pb}$, and maybe $\mathrm{Cd}$ too. This soil contamination combined with the enhanced concentrations found in the effluent can point out a probable groundwater contamination.
\end{abstract}




\section{SUMẢRIO}

Página

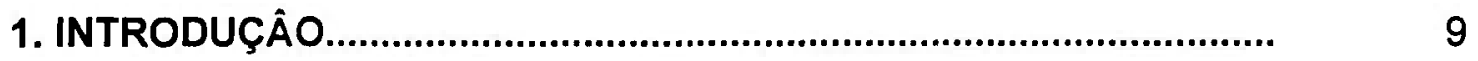

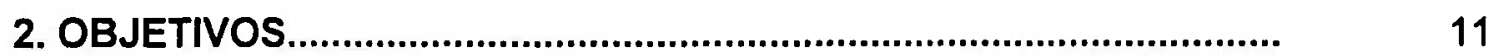

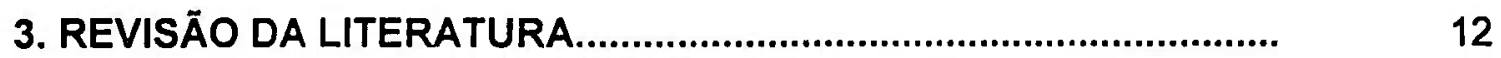

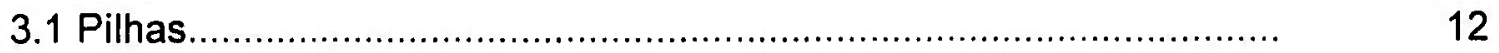

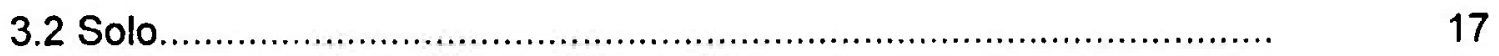

3.2.1 Propriedades fisico-químicas do solo............................................. 18

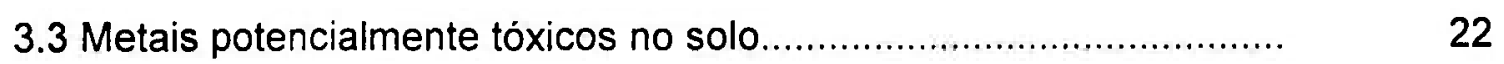

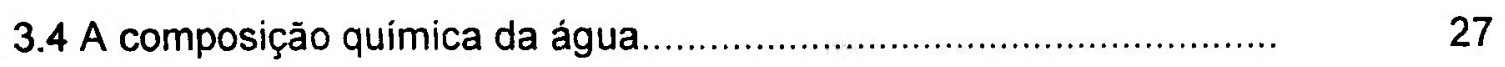

4. MATERIAIS E MÉTODOS.............................................................. 31

4.1 Coleta das colunas de solo e contexto Geológico.............................. 31

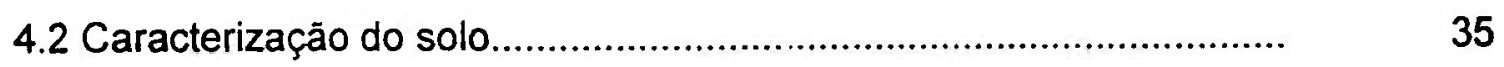

4.3 Caracterização do solo Montagem do sistema de lixiviação.............. 40

4.4 Solução simuladora de "água de chuva".......................................... 41

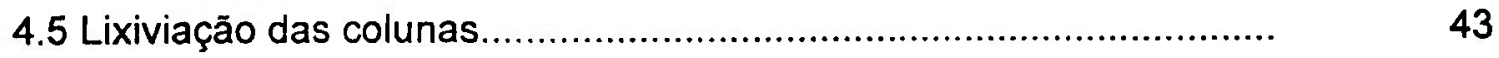

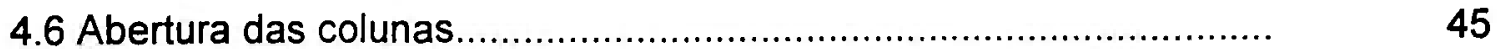

5 RESULTADOS............................................................

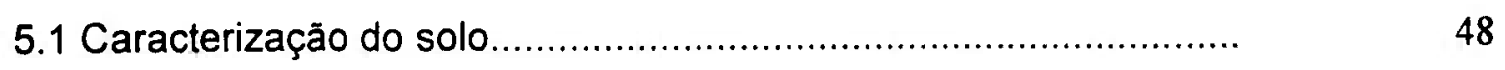

5.2 Solução "água de chuva".............................................................. 51

5.3 Efluentes das colunas de solo..................................................... 52

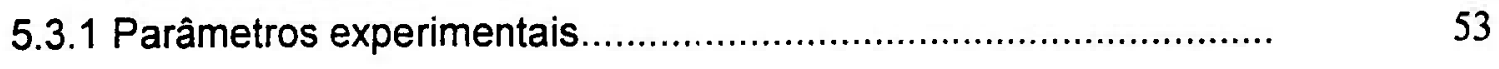

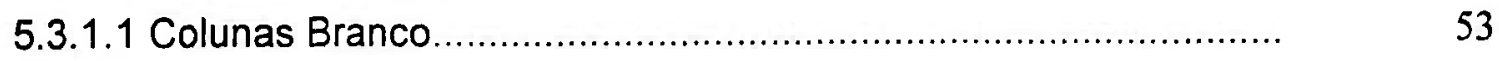




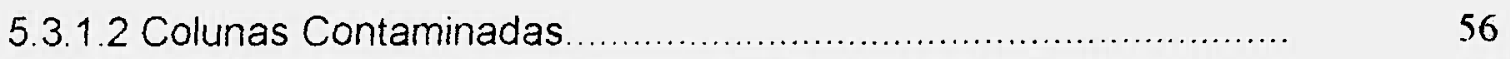

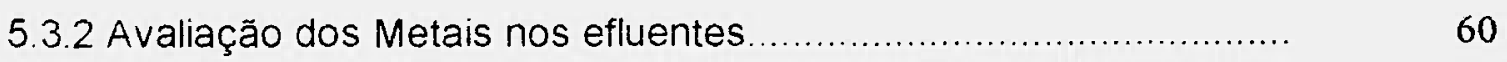

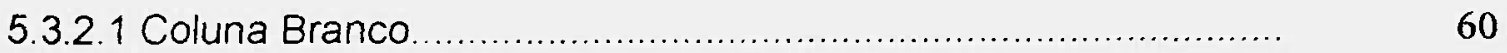

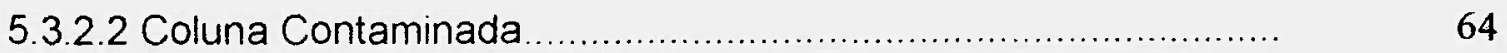

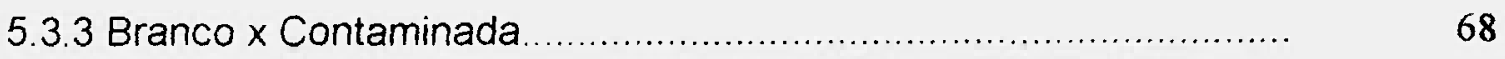

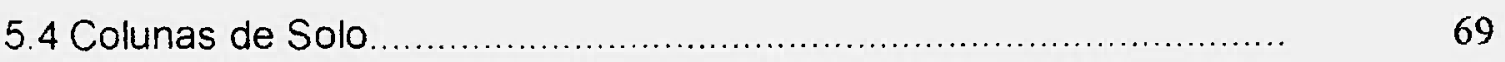

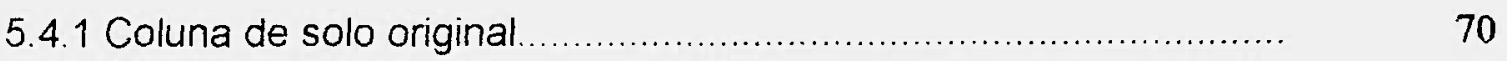

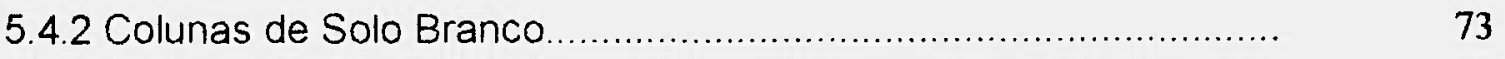

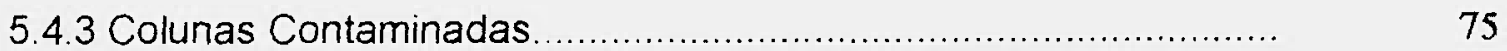

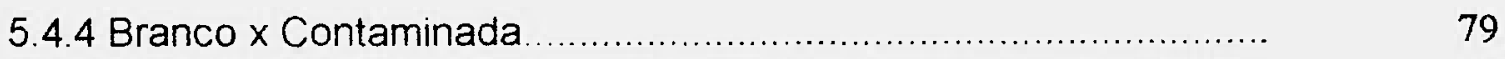

5.5 Avaliação da contaminação ambiental ......................................... 80

5.5.1. Contribuição da pilha por balanço de massa............................... 80

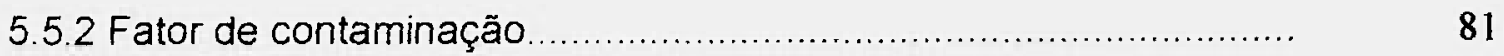

5.5.3 Estimativa da porcentagem de lixiviação dos metais da pilha....... 82

5.5.4 Comparação com os valores CETESB ....................................... 83

5.5.4.1 Avaliação da contaminação do solo ........................................ 84

5.5.4.2 Avaliação da contaminação da água subterrânea ...................... 85

5.5.5 Conclusão da avaliação da contaminação................................... 87

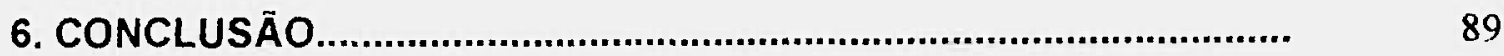

REFERÊNCIAS BIBLIOGRÁFICAS................................................. 90

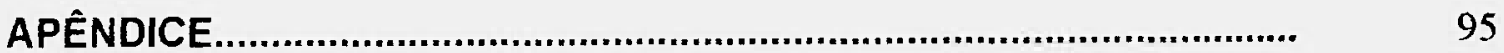




\section{INTRODUÇÃO}

No Brasil, segundo a Associação Brasileira da Indústria Elétrica e Eletrônica (ABINEE) são produzidos 800 de pilhas primárias de uso doméstico, $70 \%$ das pilhas fabricadas são chamadas comuns ou zinco-carbono, e $30 \%$ são referentes às pilhas do tipo alcalina. Uma grande variedade de substâncias tóxicas é utilizada na fabricação das pilhas. Os componentes metálicos que apresentam toxicidade sāo: zinco, manganês cádmio, chumbo, niquel, e mercúrio.

De acordo com as fichas de segurança - MSDS (Material Safety Data Sheet) das Empresas Duracell e Eveready a pilha é classificada como resíduo não perigoso. Os efeitos da exposição às pilha são pequenos enquanto os metais e outras substâncias quimicas estiverem blindados dentro da embalagem da pilha. Uma exposição potencial pode ocorrer em caso de vazamento ou ruptura da blindagem da pilha. Considerações sobre impactos ambientais sugerem uma disposição adequada, pois as pilhas contêm metais tóxicos e podem prejudicar 0 meio ambiente.

Para minimizar e direcionar esta problemática o governo definiu e aprovou em 30 de junho de 1998, a Resolução 257, do Conselho Nacional do Meio Ambiente (CONAMA). Segundo o artigo 13 da resolução, as pilhas de uso doméstico depois de exauridas podem ser dispostas juntamente com os resíduos domiciliares, em aterros licenciados, desde que atendam aos limites previstos pelo artigo $5^{\circ}$ e $6^{\circ}$ da resolução quanto à quantidade dos metais $\mathrm{Hg}, \mathrm{Cd} \mathrm{e} \mathrm{Pb}$ adicionados à formulação. No entanto, os metais $\mathrm{Mn}$ e $\mathrm{Zn}$, que correspondem a $48 \%$ em massa da composição média da pilha zinco-carbono (Hurd et al, 1993) não são contemplados pela legislação. Tanto o zinco quanto o manganês, apesar de serem essenciais aos seres vivos em baixas concentrações, são particularmente tóxicos quando em concentraçōes elevadas.

Segundo dados do Instituto Brasileiro de Geografia e Estatística (IBGE), $36 \%$ do lixo doméstico são dispostos em aterro sanitário, $37 \%$ em aterros controlados, e os $27 \%$ restante em lixão. Com exceção do aterro sanitário, os demais meios de disposição não possuem medidas de proteção ao meio 
ambiente ou à saúde pública. Assim, os metais presentes na pilha, devido à corrosão da blindagem, podem ser lixiviados, causando a contaminação do solo e das águas subterrâneas.

Sabe-se que atualmente as principais indústrias produtoras de pilhas vêm buscando minimizar o impacto gerado por estas com a inclusão de componentes inertes na composição das pilhas. Porém, temos que levar em conta que há um passivo significativo de metais tóxicos referentes aos últimos quarenta anos de produção e comercialização de pilhas, onde mercúrio, cádmio, chumbo, cromo e niquel ainda eram adicionados em concentrações consideráveis. Apesar da baixa concentração destes metais tóxicos a sua introdução no solo poderá acarretar em alteração na concentração natural dos metais no solo.

O $\mathrm{Zn}$ e principalmente o $\mathrm{Mn}$, constituintes naturais do solo e metais de baixa toxicidade, geralmente não são avaliados como metais potencialmente poluidores do solo. A presença de altas concentrações de $\mathrm{Zn}$ e $\mathrm{Mn}$ na pilha (48\% em peso da pilha), no entanto, poderá causar uma alteração significativa na concentração natural do solo e possivelmente atingir concentrações preocupantes, do ponto de vista ambiental.

$\mathrm{Na}$ literatura encontram-se muitas pesquisas envolvendo a reciclagem de pilhas no Brasil (Salgado et al, 2003; Souza \& Oliveira, 2001), mas nenhuma delas estuda possíveis contaminações no solo. Dentro desse contexto, o presente trabalho visa avaliar o efeito do descarte de pilhas sobre o solo com relação aos metais majoritários na pilha, $\mathrm{Zn}$ e $\mathrm{Mn}$, e dos metais tóxicos $\mathrm{Cd}, \mathrm{Pb}, \mathrm{Ni}, \mathrm{Cr}$ e $\mathrm{Cu}$. $\mathrm{O}$ experimento da contaminação do solo por metais contidos em pilhas será executado em coluna indeformada de solo, pois estas tendem a refletir condições mais realistas do solo natural. Este tipo de coleta apresenta a vantagem de preservar as características do solo em relação à densidade, a velocidade de infiltração de água, e a distribuição das frações granulométricas. 


\section{OBJETIVOS}

\section{Objetivo principal}

O presente trabalho tem por objetivo principal avaliar a possivel contaminação causada pelo descarte inadequado de pilhas $\mathrm{Zn} /$ carbono sobre um solo do tipo latossolo.

\section{Objetivos secundários.}

Avaliar a concentração dos metais manganês, zinco, chumbo, cádmio, cobre, cromo e niquel presentes no solo em coluna contaminada por pilha.

Avaliar a concentrações dos metais nos efluentes de colunas de solo contaminadas por pilhas e lixiviadas por solução simuladora de água de chuva. 


\section{REVISÃO BIBLIOGRÁFICA}

\subsection{Pilhas}

A definição de pilha dada pela Associação Brasileira de Normas Técnicas ABNT através da norma NBR 7039/87 é: a pilha é um gerador eletroquímico de energia elétrica, mediante conversão geralmente irreversivel de energia química. Por sua vez bateria é o conjunto de pilhas ou acumuladores recarregáveis interligados convenientemente.

A classificação de pilhas e baterias portáteis para uso doméstico, conforme a geração de corrente elétrica, é dividida em oito tipos: zinco/MnO2, zinco-cloreto ou "heavy duty", alcalina, mercúrio/zinco, zinco/ar, zinco/prata, litio e níquel/cádmio (Ni/Cd). Com exceção da níquel/cádmio, as demais pilhas são classificadas como primárias, isto é, de uso único. A Ni/Cd está classificada como secundária, pois é recarregável.

Nos Estados Unidos (E.U.A.) 15,8 pilhas domésticas são descartadas por habitante ao ano, essas 15,8 pilhas equivalem a $580 \mathrm{~g}$ de resíduos (Miller, 1994 apud Souza, 2003). Com base no volume total de pilhas vendidas nos E.U.A., estimou-se em 111 a 333 milhões de quilos o residuo sólido de pilhas utilizadas anualmente pela população americana (Meador, 1995 apud Souza, 2003).

Segundo a Associação Brasileira da Indústria Elétrica e Eletrônica (ABINEE, 1999), no pais são produzidos 800 milhões de pilhas e 17 milhões de baterias por ano, sendo que $70 \%$ das pilhas fabricadas são as chamadas comuns ou zinco-carbono, os $30 \%$ restantes são referentes às pilhas do tipo alcalina.

As pilhas alcalinas usam zinco em pó como eletrodo negativo (anodo), dióxido de manganês com grafite como eletrodo positivo (catodo), e hidróxido de potássio de alta condutividade como eletrólito. A composição do catodo contém $70 \%$ de $\mathrm{MnO} 2,10 \%$ de grafite, $1-2 \%$ de acetileno. $\mathrm{O}$ anodo requer zinco de alta pureza $(99,85$ a $99,90 \%$ de $\mathrm{Zn})$, geralmente adiciona-se 0,04 a $0,06 \%$ de chumbo e $0,3 \%$ de cádmio para aumentar a resistência à corrosão. $O$ zinco usado está em forma de pó prensado com gel de $\mathrm{KOH}$. Sua composição é $76 \%$ de $Z n, 7 \%$ de 
mercúrio, $6 \%$ celulose carboximetil de sódio e o resto de solução de $\mathrm{KOH}$ (Hurd,1992). A maior área superficial do zinco em pó e a maior condutividade do hidróxido de potássio em relação ao cloreto de amônio concedem à pilha uma maior durabilidade e desempenho.

Uma pilha zinco-carbono é constituida por: capa externa de aço, tampa e fundo de aço, isolantes de papelão ou plástico, eletrodo de grafite, copo metálico de zinco (pólo negativo) e a pasta eletrolitica de $\mathrm{NH}_{4} \mathrm{Cl}$ e $\mathrm{ZnCl}_{2}$ contendo $\mathrm{MnO}_{2}$ (pólo positivo) (FIG. 3.1). Na liga do copo de zinco são adicionados $0,01 \%$ de $\mathrm{Pb}$ e $\mathrm{Cd}$ para aumentar a resistência à corrosão. Impurezas como $\mathrm{Ni}, \mathrm{Cu}, \mathrm{Fe}, \mathrm{e}$ Co também podem estar presentes na liga. As pilhas atuais são isentas de mercúrio (Souza, 2003).

Os dados da formulação básica para a pilha zinco-carbono, segundo Hurd et al, 1993, estão na TAB. 3.1.
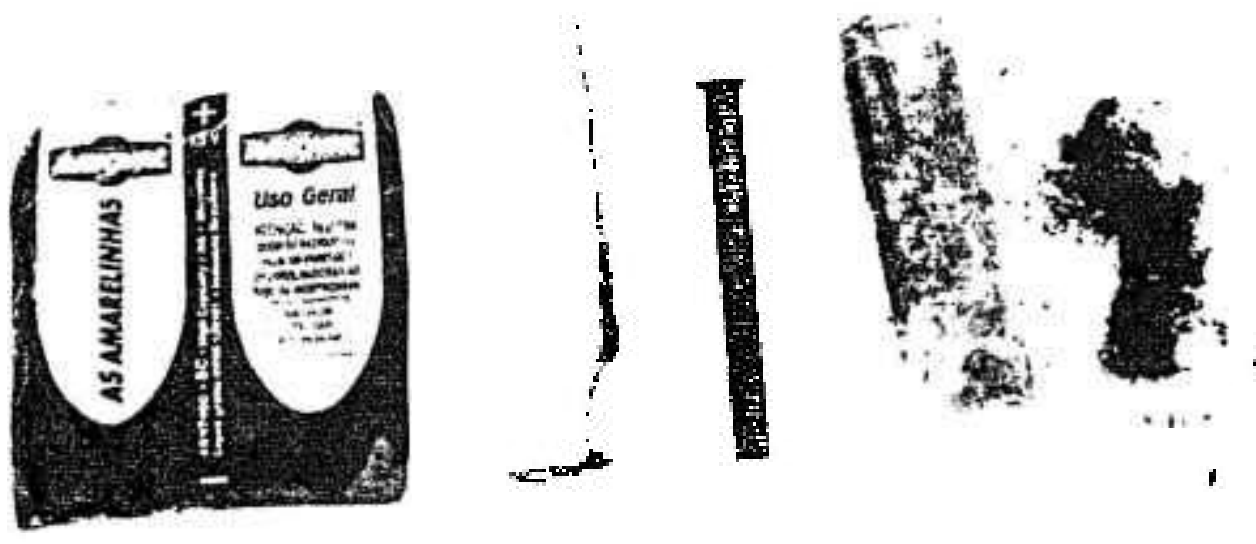

FIGURA 3.1 - Principais constituintes de uma pilha zinco-carbono, a foto mostra na seqüência o rótulo, o papelão, o eletrodo de grafite, copo de zinco e a pasta interna.

As prováveis reações que ocorrem durante o processo de descarga de uma pilha zinco-carbono são representadas pelas reações (equações $3.1,3.2$, 3.3): 


$$
\begin{aligned}
& >\text { Catodo: } \mathrm{MnO}_{2}+2 \mathrm{H}_{2} \mathrm{O}+2 \mathrm{e}^{-} \rightarrow 2 \mathrm{MnO} . \mathrm{OH}+2 \mathrm{OH}^{-} \\
& >\text {Global: } \mathrm{Zn}^{2+}+2 \mathrm{MnO}_{2} \rightarrow \mathrm{ZnO}+\mathrm{Mn}_{2} \mathrm{O}_{3}
\end{aligned}
$$

TABELA 3.1 - Composição média das pithas zinco-carbono.

\begin{tabular}{cc}
\hline Componentes da pilha & Porcentagem em Peso (\%) \\
\hline Carbono & 5,13 \\
Dióxido de Manganês & 29,48 \\
Cloreto de Amônio & 0,70 \\
Cloreto de Zinco & 6,07 \\
Água & 17,00 \\
Zinco & 19,08 \\
Total & 77,47 \\
\hline
\end{tabular}

Fonte - Hurd et al., 1993.

O descarte de pilhas no lixo urbano ou no solo gera problemas nas estações de tratamento de lixo, poluição do solo, das águas superficiais e subterrâneas e acumulação de substâncias tóxicas na cadeia alimentar. Tanto o zinco quanto o manganês, apesar de serem essenciais aos seres vivos em baixas concentrações, são tóxicos quando em concentraçōes elevadas.

Para minimizar e direcionar esta problemática ambiental, o governo através da Resolução CONAMA 257/1999, definiu procedimentos, responsabilidades e prazos de adequação, quanto ao descarte e comercialização de pilhas e baterias. Conforme o artigo 13 da resolução Conama $n^{\circ} 257 / 1999$ as pilhas comuns, depois de exauridas, podem ser descartadas no lixo doméstico, desde que atendam aos limites previstos pelo artigo $5^{\circ}$ e $6^{\circ}$, quanto à quantidade dos metais $\mathrm{Hg}, \mathrm{Cd}$ e $\mathrm{Pb}$ em sua composição (Cd:0,015\%; $\mathrm{Pb}: 0,200 \%$ e $\mathrm{Hg}: 0,010 \%$ em peso na pilha). No entanto, os metais $\mathrm{Mn}$ e $\mathrm{Zn}$, que correspondem aproximadamente a $48 \%$ em massa da composição média da pilha zincocarbono. não são contemplados pela legislação.

A resolução CONAMA 257/1999 apesar de estabelecer os teores máximos dos metais cádmio, mercúrio e chumbo, não estabelece os métodos e as técnicas a serem utilizados pra a determinação e controle desses teores. 
Grande parte dos estudos sobre os teores de metais nas pilhas está ligada recuperação do zinco e manganês principalmente na pasta eletrolítica. Com exceção da pasta eletrolítica, outros componentes da pilha como o copo de zinco, os eletrodos metálicos externos e a blindagem dificilmente são abordados em estudos.

Hinrichs \& Soares (2001), analisaram o eletrólito de 30 pilhas zincocarbono tipo AA de marcas comerciais comuns para obter os teores de cádmio, chumbo e mercúrio. A pasta eletrolítica, representando $40 \%$ em massa da pilha, foi prensada e na compactação houve a liberação de líquido corrosivo com pH em torno 2-3. Dez gramas da pasta foram transformadas em pastilhas e submetidas à análise por Fluorescência de Raios-X. Os teores obtidos foram $974 \mathrm{mg} \mathrm{kg}^{-1} \mathrm{de} \mathrm{Cd}$, $8 \mathrm{mg} \mathrm{kg}^{-1}$ de $\mathrm{Hg}$ e $148 \mathrm{mg} \mathrm{kg}^{-1}$ de $\mathrm{Pb}$. Apenas o cádmio encontra-se acima dos valores estabelecidos pela resolução CONAMA 257/1999, pois com $0,1 \%$ em peso de Cd na pasta interna, isso representaria algo em torno de $0,040 \%$ em peso de $\mathrm{Cd}$ na massa total da pilha. Os autores também analisaram os eletrodos externos, sem contudo quantificá-los, apenas indicam que esses valores são significativos. Não há indicação se as pilhas eram exauridas ou novas.

Souza \& Tenório (2001) estudaram amostras de pilhas zinco-carbono exauridas de diversos fabricantes e tamanhos. As baterias foram desmanteladas gerando frações empregadas nos ensaios de caracterização e lixiviação com ácido sulfúrico. As amostras de ambas as pilhas foram submetidas á análise por Difração de Raios-X e Espectrometria de Absorção Atômica, fornecendo a seguinte composição média mostrada na TAB. 3.2.

TABELA 3.2 - Composição química em termos de metais das pilhas zinco carbono.

\begin{tabular}{cc}
\hline Metais & Composição \\
\hline Zinco & $8,5-13 \%$ \\
Manganês & $47-53 \%$ \\
Ferro & $1,6-2,3 \%$ \\
Chumbo & $0,04 \%$ \\
Mercúrio & $0,36 \mathrm{mg} \mathrm{kg}^{-1}$ \\
Cádmio & $0,39 \mathrm{mg} \mathrm{kg}^{-1}$ \\
\hline
\end{tabular}

Fonte - Souza e Tenório, 2001. 
Afonso et al. (2003) empregaram a Espectrometria de Absorção Atômica para a análise de manganês e zinco na pasta eletrolítica de pilhas zinco-carbono do tipo $A A$ de quatro diferentes fornecedores. As pilhas foram desmontadas manualmente, visando a separaçāo de seus componentes, que foram pesados em balança analitica e os resultados encontram-se na TAB. 3.3.

TABELA 3.3 - Porcentagem em peso das pilhas zinco-carbono.

\begin{tabular}{|c|c|c|c|c|}
\hline \multirow[b]{2}{*}{ Partes } & \multicolumn{4}{|c|}{$\%$ em peso dos componentes da pilha } \\
\hline & Invólucro & $\begin{array}{c}\text { Pasta } \\
\text { eletrolítica }\end{array}$ & Catodo & $\begin{array}{l}\text { Perda na } \\
\text { abertura }\end{array}$ \\
\hline Lote 1 & 44,2 & 49,1 & 5,6 & 1,1 \\
\hline Lote 2 & 40,6 & 50,9 & 5,9 & 2,6 \\
\hline
\end{tabular}

Fonte - Afonso et al.,2003.

A pasta eletrolitica foi tratada por dois métodos de fusão: $\mathrm{NaOH}$ e $\mathrm{KHSO}_{4}$, durante cinco horas a $600^{\circ}$.C. Esse método origina sais que são solúveis em água, e sais que são solúveis em $\mathrm{HCl}$. Na fração solúvel em água foi detectado zinco e manganês, na fração solúvel em $\mathrm{HCl}$ foram detectados mercúrio, chumbo e ferro, em ambas as fusões. $O$ balanço total de manganês e zinco contido na pasta encontra-se na TAB. 3.4. Não há indicação se a pilha era exaurida ou nova.

TABELA 3.4 - Balanço total do manganês e do zinco na pasta eletrolítica.

\begin{tabular}{rrrrrr}
\hline Pithas & $\begin{array}{r}\text { P.E. total } \\
\text { antes da } \\
\text { fusão }(\mathrm{g})\end{array}$ & $\begin{array}{c}\text { Massa total } \\
\text { de Mn na } \\
\text { P.E. }(\mathrm{g})\end{array}$ & $\begin{array}{c}\text { Massa total } \\
\text { de Zn na P.E. } \\
(\mathrm{g})\end{array}$ & $\begin{array}{c}\text { \% p/p de Mn } \\
\text { na P.E. }\end{array}$ & $\begin{array}{c}\text { \% p/p de Zn } \\
\text { na P.E. }\end{array}$ \\
\hline Lote 1 & 8,05 & 3,4 & 1,2 & 42,2 & 14,9 \\
Lote 2 & 5,42 & 2,5 & 0,8 & 46,1 & 14,8 \\
\hline
\end{tabular}

*P.E. - Pasta eletrolítica

Fonte - Afonso et al.,2003.

Salgado et al. (2002) analisou a pasta eletrolitica das pihas zinco-carbono exauridas de diversos fabricantes. A pasta foi lixiviada com água régia (3:1 
$\mathrm{HCl}: \mathrm{HNO}_{3}$ ) e submetida a análise por Espectrometia de Absorção Atômica, os resultados encontram-se na TAB. 3.5.

TABELA 3.5 - Porcentagem em peso dos metais $\mathrm{Zn}, \mathrm{Mn}, \mathrm{Ni}, \mathrm{Cd}$, e Fe encontrados na solução lixiviada da pasta eletrolitica pela águarégia.

\begin{tabular}{llllll}
\hline Pilhas & Zinco (\%) & Manganês (\%) & Niquel (\%) & Cádmio (\%) & Ferro (\%) \\
\hline Lote 1 & 4,92 & 23,58 & 0,007 & 0,0004 & 0,98 \\
Lote 2 & 5,05 & 9,04 & 0,006 & 0,0002 & 0,18 \\
\hline
\end{tabular}

Fonte - Salgado et al, 2002.

Devido às diferentes técnicas de análise, os resultados variam muito, no entanto, pode-se afirmar com certeza que zinco e manganês são os elementos em maior porcentagem em peso na pilha. Chumbo, níquel, cádmio e cromo também são encontrados, porém em quantidades pequenas.

\subsection{Solo}

O solo é resultante da ação do clima e da biosfera sobre a rocha, cuja transformação em solo se realiza durante um certo tempo e é influenciada pelo relevo. É constituido por partes sólidas, líquidas e gasosas, é composta de $95 \%$ de material inorgânico (argilominerais, areia e silte) e $5 \%$ de matéria orgânica, com teores variáveis dependendo das caracteristicas regionais.

São formados por múltiplos compostos em sistemas bioquímicos abertos contendo sólidos, liquidos e gases. Esses sistemas são designados abertos, pois o solo troca ambos matéria e energia com a atmosfera, biosfera e hidrosfera ao seu redor. Esse fluxo de energia e matéria é altamente variável e essencial no desenvolvimento do perfil do solo e de sua fertilidade.

O limite superior do solo é a atmosfera. Os limites laterais são contatos com outras espécies de solos vizinhos, contatos com afloramentos de rocha, materiais detríticos inconsolidados, aterros ou encontros com terrenos sob espelho d'água permanente. O limite inferior é dificil de ser definido, pois o solo passa gradualmente para rocha dura ou materiais saproliticos que não apresentam indicações de atividade biológica (EMBRAPA,1999). 
A parte sólida é composta por pequenos fragmentos de rocha e minerais de várias espécies (Brady \& Buckman, 1989). A parte gasosa é uma mistura de gases provenientes da atmosfera e das reações processadas no sistema água-solo-planta, geralmente é pobre em oxigênio e rica em gás carbônico, é úmida, chegando facilmente a $100 \%$ de umidade relativa. A fase líquida é constituída de água que se acha retida no solo (Moniz et al, 1972).

\subsubsection{Propriedades físico-químicas do solo}

As propriedades físico-químicas do solo são: teor de matéria orgânica, o $\mathrm{pH}$, a granulometria e a capacidade de troca catiônica .

A matéria orgânica do solo representa uma acumulação de residuos animais e vegetais parcialmente decompostos, ocorrendo no solo em intima relação com os constituintes minerais. O teor de matéria orgânica no solo é baixo variando de três a cinco por cento em peso no caso de solo mineral típico de superficie (Brady e Buckman,1972). Uma das propriedades da matéria orgânica é a capacidade de troca de cátions. Um ion metálico liga-se a matéria orgânica na forma de complexo, esse processo recebe o nome de quelação.

A degradação da matéria orgânica corresponde a uma reação de óxido-redução que utiliza oxigênio dissolvido na água, ou outro receptor de elétron, para produzir gás carbônico (equação 3.4). O gás carbônico produzido corresponde, por sua vez, a uma importante fonte de acidez (equações $3.4,3.5$ e 3.6) (Bertolo, 2001):

$$
\begin{aligned}
& >\mathrm{CH}_{2} \mathrm{O}+\mathrm{O}_{2} \rightarrow \mathrm{CO}_{2}+\mathrm{H}_{2} \mathrm{O} \\
& >\mathrm{CO}_{2}+\mathrm{H}_{2} \mathrm{O} \leftrightarrow \mathrm{H}_{2} \mathrm{CO}_{3} \\
& >\mathrm{H}_{2} \mathrm{CO}_{3} \leftrightarrow \mathrm{H}^{+}+\mathrm{HCO}_{3}^{-}
\end{aligned}
$$

O composto $\mathrm{CH}_{2} \mathrm{O}$ da equação 3.4 é a simplificação de um composto orgânico complexo e que corresponde a uma mistura de várias substâncias. $A$ matéria orgânica tem também alguns constituintes menores como fósforo, potássio, nitrogênio e enxofre que são liberados durante a degradação.

A elevada oferta de acidez da água gerada pelas equações 3.5 e 3.6 atua na dissolução de minerais primários do perfil de alteração do solo. Este processo de dissolução causa o consumo de acidez e a liberação de elementos 
para a água; porém, a oxidação da matéria orgânica e a respiração das raízes constituem uma fonte de reposição de gás carbônico, deste modo $\circ \mathrm{CO}_{2}$ volta a reagir com a água, produzindo mais acidez. Assim a matéria orgânica, gera acidez que reage com os materiais geológicos originais, transformando-os em espécies mais estáveis neste ambiente (Freeze \& Cherry, 1979).

Após seco, o solo pode reter uma certa quantidade de água ao redor das superficies coloidais. Na água do solo existem pequenas quantidades variáveis de sais minerais, oxigênio e gás carbônico, constituindo uma solução diluida que chamamos de solução do solo.

Se, por exemplo, o cálcio é o cátion que prevalece entre os adsorvidos, ele prevalecerá também na solução do solo, que será neutra ou quase neutra. Se - alumínio predominar entre todos os cátions adsorvidos na superfície dos colóides, ele predominará também na solução do solo que, conseqüentemente, se torna ácida (Lepsch, 2002).

O pH do solo pode exercer influência de duas maneiras sobre a absorção de nutrientes e o crescimento das plantas: 1) mediante o efeito direto dos íons hidrogênio; ou 2) indiretamente, mediante sua influência na disponibilidade de nutrientes e de ions tóxicos. Na maioria dos solos, o segundo aspecto tem maior importância. A disponibilidade de vários nutrientes essenciais é drasticamente afetada pelo $\mathrm{pH}$ do solo, assim como a solubilidade de certos elementos tóxicos ao crescimento das plantas (Brady \& Buckman, 1968).

As reações de adsorção e troca iônica são reconhecidas como os fenômenos químicos mais importantes que ocorrem no solo, principalmente pela sua relevância nos processos de nutrição vegetal, e nos processos de retenção de contaminantes orqânicos e de metais tóxicos (McBride, 1994; Appelo \& Postma, 1993). O processo que mais afeta o comportamento dos metais no solo é a adsorção, controlando as concentrações dos ions e complexos na solução do solo e exercendo influência na sua biodisponibilidade (Maclean \& Bledsoe,1992; Alloway, 1996).

Adsorção é a atração de ions ou moléculas presentes numa solução à uma fase sólida de elevada superfície especifica como as argilas, a matéria orgânica e óxidos e hidróxidos. Normalmente estas superficies especificas apresentam-se negativamente carregadas, atraindo cátions para a sua superficie, contribuindo para a estabilização elétrica. 
As variáveis que definem se haverá ocorrência de adsorção de cátions ou ânions são: o tipo de material adsorvente e o pH da solução percolada. Se o $\mathrm{pH}$ da solução percolada for mais elevado que $\mathrm{opH}$ do material adsorvente no qual a carga elétrica da sua superfície seja zero, haverá condições para a adsorção de cátions, e vice-versa (TAB. 3.6) (Bertolo, 2001).

TABELA 3.6 - Medidas de capacidade de troca de cátions (CTC) e de pH de algumas argilas.

\begin{tabular}{lcc}
\hline Material (argilas) & CTC (meq $\left.100 \mathrm{~g}^{-1}\right)$ & $\mathrm{pH}$ \\
\hline Caulinita & 3 a 15 & 4 a 5 \\
Montmorilonita & 80 a 120 & 2,5 \\
Goetita & 150 a 400 & 7 a 8 \\
\hline
\end{tabular}

Fonte - Bertolo, 2001.

Deste modo, a adsorção e a troca catiônica dependem da capacidade de troca de cátions (CTC), que é a medida quantitativa da capacidade de retenção de cátions pelos materiais, normalmente expresso em equivalentes de cargas positivas por massa de material adsorvente, variando conforme as diferentes superfícies especificas. Os materiais do solo retém com maior intensidade os ions de maior valência e de menor raio iônico hidratado. Os principais cátions que participam das reações de troca catiônica são o cálcio, magnésio, potássio, sódio, hidrogênio e alumínio.

Os materiais que compõe a textura do solo e que influenciam a CTC encontram-se divididos em frações, cujos limites convencionais atualmente usados no Brasil estão listados conforme a TAB. 3.7.

Geralmente as partículas menores, argila são as mais ativas quimicamente do que as maiores, como a areia. A intensa atividade da argila ocorre devido ao pequeno tamanho de suas partículas, fazendo com que estas possuam propriedades coloidais. A mais importante propriedade coloidal da argila é a afinidade pela água e por elementos quimicos nela dissolvidos (FIG. 3.2). Essa afinidade é devida principalmente à existência de cargas elétricas nessa superficie (Lepsch, 2002). 
TABELA 3.7 - Frações granulométricas segundo os limites convencionais atualmente usados no Brasil.

\begin{tabular}{ll}
\hline Frações & Granulometria \\
\hline Areia & 2 a $0,05 \mathrm{~mm}$ \\
Silte & 0,05 a $0,002 \mathrm{~mm}$ \\
Areia & $>0,002 \mathrm{~mm}$ \\
\hline
\end{tabular}

Fonte - Lepsch, 2002.

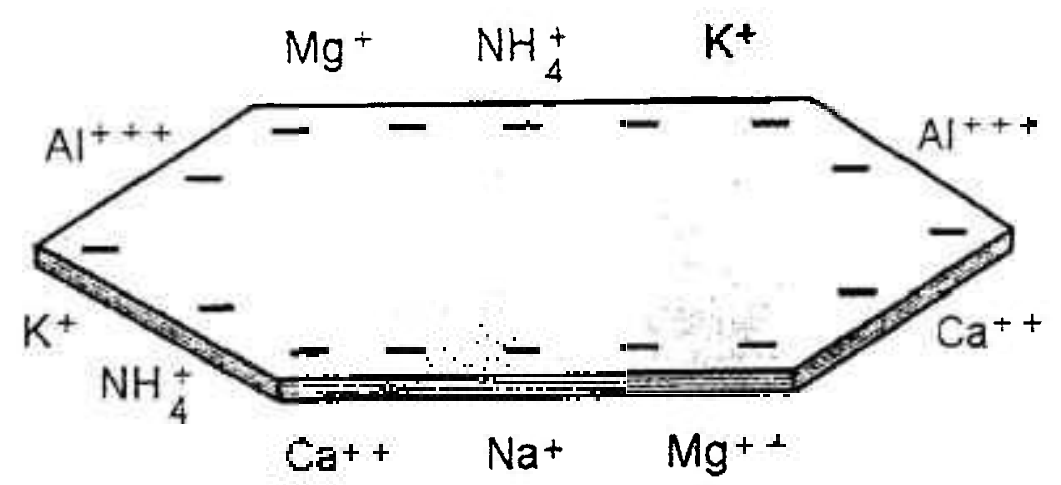

FIGURA 3.2 - Propriedade coloidal da argila: afinidade pela água e por elementos químicos nela dissolvidos (Lepsch, 2002).

Como conseqüência, a quantidade e a proporção dos componentes. de tamanho menor (argila e silte) e maior (areia), irão juntamente com o pH e a quantidade de matéria orgânica determinar a capacidade do solo de adsorver moléculas de água e de cátions.

O solo do tipo latossolo tem a maior representação geográfica no Brasil, no Estado de São Paulo ele representa 52\% do solo local (FIG. 3.3). Os latossolos são caracteristicos de zonas tropicais, onde são submetidos a um intenso intemperismo devido as abundantes chuvas.

$O$ horizonte $B$ dos solos latossólicos são profundos, em razão da enorme lixiviação a que estão sujeitos, tanto a sílica como outros elementos são removidos do perfil do solo, fazendo com que ocorra um enriquecimento relativo de óxidos de ferro e de aluminio (Oliveira et al, 1992). 
Quimicamente, os Latossolos são em sua quase totalidade distróficos, ácidos e com baixos valores de capacidade de troca catiônica (CTC). Os valores de $\mathrm{pH}$ situam-se entre 4,0 e 5,5 , o que os caracteriza como fortes e medianamente ácidos (EMBRAPA,1999). Os teores de carbono em latossolos argilosos variam de 0,5 a $2,4 \%$ Os valores médios de CTC no horizonte $A$ dos Latossolos argilosos variam entre 3,9 a $13,9 \mathrm{cmol}_{\mathrm{c}} / \mathrm{dm}^{3}$.

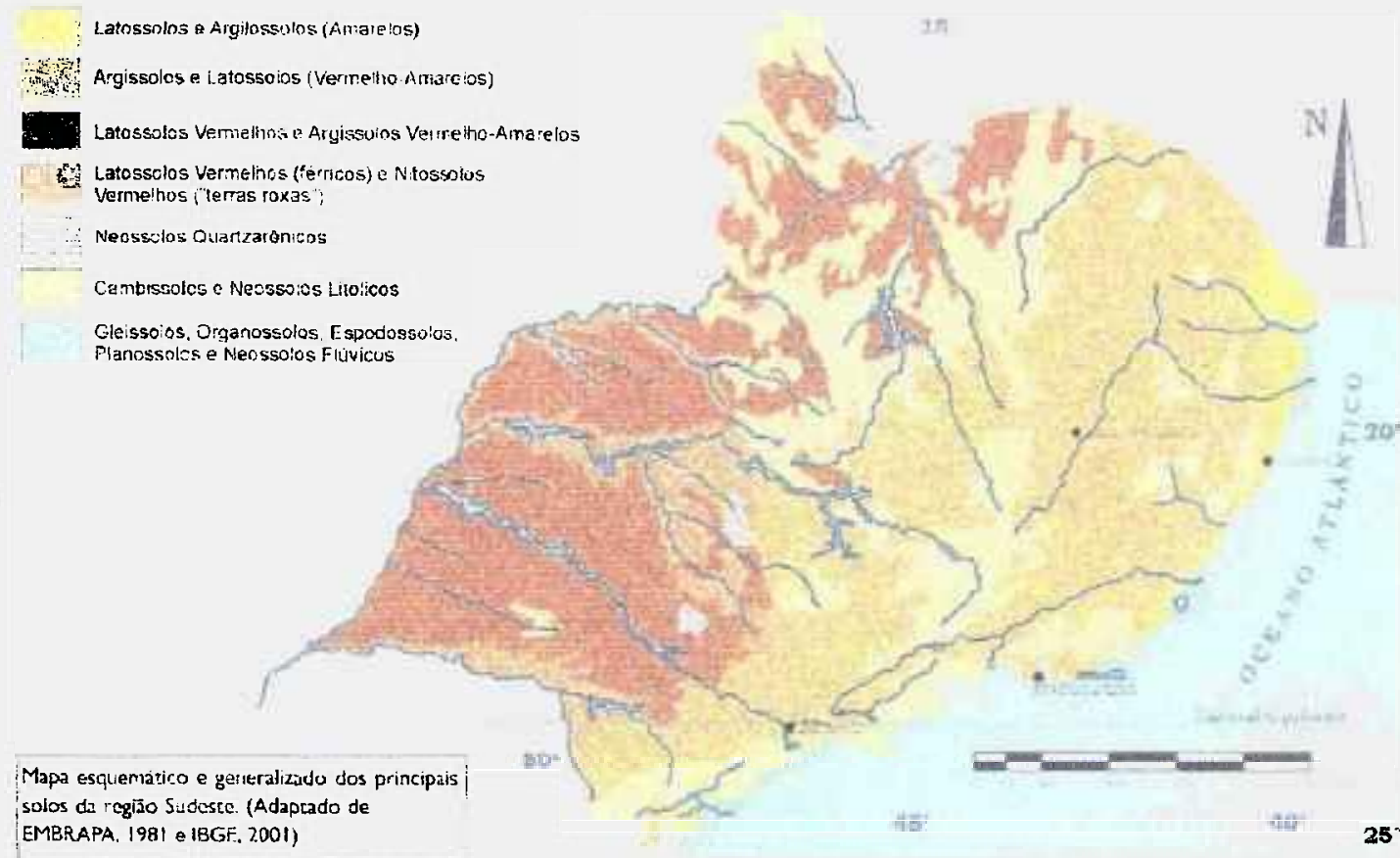

FIGURA 3.3 - Mapa esquemático e generalizado dos principais solos da região sudeste, adaptado de IBGE, 2001e EMBRAPA, 1981 por Lepsch, 2002.

\subsection{Metais potencialmente tóxicos no solos}

A origem dos metais potencialmente tóxicos no solo pode ser tanto geoquímica quanto antrópica. Os metais traços são quase sempre constituintes de rochas igneas e são incorporados na rede cristalina pelo processo de substituição isomórfica de elementos maiores ( $\mathrm{Al}, \mathrm{Fe}$ ), no momento de cristalização. As rochas sedimentares e argilitos também podem concentrar grande quantidade de metais, nos arenitos essa propriedade é menor.

$\mathrm{Na}$ natureza o conteúdo dos metais no solo é definido pelos processos atuantes no intemperismo do material parenteral. Inicialmente, ele tende a ser 
semelhante aos minerais que constituem a rocha original. Com o passar do tempo a porcentagem destes metais será diferente, devido a influência de reações e processos geoquímicos como dissolução, hidratação, hidrólise, oxidação, redução e carbonatação. São estes os principais responsáveis pelo processo de intemperismo quimico da rocha e conseqüentemente formação do solo (Kabata \& Pendias, 1992).

Os metais traços podem vir a ser mobilizados por dissolução de minerais, e fixados por minerais secundários e neoformados, ou pela matéria orgânica, associada ou não a estes minerais. A competição existente entre alguns metais também pode vir a alterar a concentração dos mesmos ao longo do perfil do solo.

Os metais de origem antrópica no solo são provenientes de várias fontes (emissão de gases, minerações industrias, fertilizantes, resíduos), e a sua dispersão ou absorção depende das propriedades químicas e fisicas do solo. Esses metais podem ser potencialmente tóxicos dependendo da sua concentração em solos e águas subterrâneas

No solo, os metais provenientes de baterias ou pilhas, podem estar sob diferentes formas químicas, disponiveis ou não às plantas, e/ou sujeitos à lixiviação. As características mineralógicas dos solos, assim como a natureza das substâncias húmicas, são elementos responsáveis pela retenção de metais no solo.

Entre os componentes do solo, sabe-se que além das substâncias húmicas, os minerais de argila, óxidos e sais de carbonato, podem funcionar como adsorventes de metais tóxicos. Há vários mecanismos pelos quais os metais podem se ligar aos minerais, como a difusão sólida de metais nos minerais, adsorção especifica, co-precipitação, adsorção de metais e ligação orgânica na superfície dos minerais.

\section{Zinco}

O zinco é um metal de cor branco-azulada, ocorre na crosta terrestre em moderada abundância, e pode ser encontrado em minerais de enxofre, especialmente como esfalerita $\mathrm{ZnS}$. A oxidação na superficie libera o ion $\mathrm{Zn}^{2+}$ solúvel, com formas ocasionais de carbonato e minerais de sílica (Cox, 1997). 
O zinco caracteriza-se pela sua alta resistência à corrosão, o que permite o seu emprego como revestimento protetor de vários produtos. $O$ óxido e pó de zinco são usados em produtos químicos e farmacêuticos, cosméticos, borrachas, explosivos, tintas e papel. O zinco é também utilizado como anodo para proteção catódica do aço ou ferro.

As formas de zinco nos solos podem incluir: solúvel em $\mathrm{H}_{2} \mathrm{O}$, trocável e extraivel na superficie, precipitados, ocluso em hidróxidos, organismos vivos e residuos biológicos, e como constituinte de minerais (Marshall \& Fairbridge, 1999). Complexa-se facilmente aos ácidos fúlvicos, o que o torna muito móvel no solo (Sposito, 1982). Em solos contaminados por altos teores de $\mathrm{Zn}$ e pH abaixo de 6 , ocorre uma tendência de precipitação de óxidos, hidróxidos e hidrocarbonetos de Zn (McBride, 1989).

Alloway (1990) sugere que o mecanismo de adsorção do ín $\mathrm{Zn}^{2+}$, consiste na adsorção do metal pela fase coloidal do solo, carregada por forças negativas. Neste processo, ocorre desorção de quantidade equivalente de outros cátions da fase sólida para a solução do solo. Os principais cátions que participam das reações de troca catiônica são o cálcio, magnésio, potássio, sódio, hidrogênio e aluminio.

\section{Manganês}

O manganês aparece no solo em três valências: bivalente $\mathrm{Mn}^{2+}$ (como cátion adsorvido ou na solução), trivalente (como $\mathrm{MnO}_{3}$ ),e tetravalente (como $\mathrm{MnO}_{2}$ ). As três formas constituem um conjunto de equilibrio dinâmico (Catani \& Gallo, 1951). A ocorrência de $\mathrm{Mn}^{3+}$ e $\mathrm{Mn}^{4+}$ é favorecida pela elevação do pH em condições oxidantes.

A mobilidade do Mn no solo é extremamente sensivel às condiçōes do solo (acidez, umidade, atividade biológica, etc) o que faz com que a sua solubilidade no solo varie intensamente, e, conseqüentemente, a sua concentração varie de deficiente até niveis considerados tóxicos (McBride,1994).

Sob condições de $\mathrm{pH}$ neutro ou baixo, e em ambientes redutores o manganês é solúvel e sua concentração em água subterrânea pode ser relativamente alta (maior que $1 \mathrm{mg} \mathrm{L}^{-1}$ ). Quando o ambiente é oxidante, e o pH é neutro ou básico, o manganês precipita-se como óxido ou hidróxido (Ishimine, 2002). 


\section{Chumbo}

O chumbo é um metal cinzento, azulado brilhante, não elástico, mole, dúctil, maleável, razoável condutor de calor e eletricidade. Considerado um excelente metal para proteção da corrosão atmosférica em razão da sua rápida oxidação superficial em forma de película de óxido, formando o protóxido de chumbo.

O chumbo raramente é encontrado no seu estado natural, mas sim, em combinaçōes com outros elementos. A galena (PbS), é um sulfeto de chumbo, que geralmente ocorre associada com a prata, é o seu mineral-minério mais importante. $O$ zinco, o cobre, o ouro e o antimônio são outros metais que podem aparecer associados ao chumbo.

O chumbo é o sexto metal de maior utilidade industrial. $\mathrm{O}$ seu uso principal é na construção de baterias para automóveis, que consomem em torno de $70 \%$ em todo mundo.

Geralmente, o chumbo se acumula nos primeiros centimetros do solo superficial, e o seu teor diminui à medida que a profundidade do perfil aumenta (Aloway,1995). Este tipo de distribuição é atribuída à matéria orgânica, mediante reciclagem do $\mathrm{Pb}$ das camadas inferiores pelas raizes das plantas. $\mathrm{O}$ chumbo antrópico apresenta o mesmo tipo de distribuição, podendo porém atingir niveis mais profundos, em torno de 30 à $45 \mathrm{~cm}$.

\section{Cádmio}

O cádmio está fortemente associado ao $\mathrm{Zn}$, e possui alta afinidade por. sulfeto. A principal fonte de cádmio é como subproduto de minério de $\mathrm{Zn}$.

No perfil de solo o $\mathrm{Cd}$ tende a concentrar-se no horizonte superficial devido a adsorção pela matéria orgânica. No entanto, ao contrário do Cu e do $\mathrm{Pb}$, - Cd apresenta um comportamento semelhante ao $\mathrm{Zn}$ na tendência de aprofundar-se no perfil de solo. A extensão e velocidade deste processo dependem das características do solo e da geomorfologia da região. (Kabata Pendias \& Pendias, 1992).

As formas que o $\mathrm{Cd}$ pode ser encontrado no solo são: trocável (adsorvido por atração eletrostática em sítios com carga negativa das argilas, matéria orgânica e óxidos hidratados), reduzida (adsorvido ou coprecipitado com óxidos, hidróxidos de $\mathrm{Fe}, \mathrm{Mn}$ presentes no revestimento de minerais de argila ou 
particulas isoladas), carbonato (solos com muito carbonato de cálcio livre), orgânico (complexado), fixado no interior da rede cristalina da argila, e em solução iônica ou complexada (Adriano, 1986).

A competição pelos sítios de adsorção dos óxidos e matéria orgânica ocorre com o cálcio, cromo, níquel e chumbo. O cádmio é um poluente potencialmente prejudicial ao meio ambiente, visto que é um metal de rápida adsorção pelo solo, com alta taxa de persistência e acumulação, provocando efeitos danosos em plantas e animais. De um modo geral são considerados solos contaminados aqueles que possuem teores de cádmio acima de $0,5 \mathrm{mg} \mathrm{kg}^{-1}$ (McBride, 1994).

\section{Níquel}

O níquel nos solos está associado mais de $50 \%$ à fração residual, isto é, na rede cristalina dos minerais, cerca de $20 \%$ aos óxidos de ferro e manganês, e pouco às frações carbonáticas, trocável e orgânica (Alloway,1995).

A forma $\mathrm{Ni}^{2+}$ é a forma mais estável encontrada nos solos, sua adsorção a óxidos, aluminosilicatos e argila é favorável a $\mathrm{pH}$ acima de seis, e baixos $\mathrm{pH}$ favorecem a forma trocável e solúvel do $\mathrm{Ni}^{2+}$. A solubilidade do $\mathrm{Ni}$ é inversamente proporcional ao $\mathrm{pH}$, a mobilidade é média em solos ácidos, e muito baixa em solos neutros ou alcalinos. Sob condições redutoras, o $\mathrm{Ni}^{2+}$ é incorporado aos sulfitos restringindo a mobilidade a valores muito baixos (McBride, 1994).

\section{Cobre}

O cobre, embora essencial à nutrição das plantas, pode apresentar caráter tóxico, quando presente em altas concentrações do solo. Esse elemento está presente em resíduos municipais e industriais, em compostos organometálicos, como agroquimicos largamente utilizados na agricultura, em fertilizante e ração animal (Silveira \& Alleoni, 1999).

O cobre apresenta expressiva afinidade por determinados grupos funcionais do solo superficial, podendo estar complexado com a fração orgânica e inorgânica. Os óxidos de aluminio, ferro e manganês e os grupos funcionais da matéria orgânica são as superficies mais representativas nos fenômenos de adsorção do elemento. O cobre forma com as superficies reativas do solo 
moléculas estáveis, que correspondem à adsorção especifica, com alta energia de ligação e estabilidade (Sparks, 1995).

\section{Cromo}

O cromo geralmente ocorre nos solos como $\mathrm{Cr}^{3+}$ e como $\mathrm{Cr}^{6+}$ na forma de cromato $\mathrm{CrO}_{4}{ }^{2-}$, no entanto, o cromato tem tendência a se reduzir espontaneamente para $\mathrm{Cr}^{3+}$, especialmente sob condições ácidas e presença de matéria orgânica (McBride, 1994).

Diversos parâmetros como pH, estado de oxidação, tipo e quantidade de matéria orgânica presentes no meio, interferem na mobilidade e solubilidade do cromo no solo. Cromo $3^{+}$é móvel somente em $\mathrm{pH}$ menor que 5 , enquanto que $\mathrm{Cr}^{6+}$ é instável e facilmente mobilizado nos solos. No entanto, $\mathrm{o} \mathrm{Cr}^{6+}$ tende a converte-se em $\mathrm{Cr}^{3+}$, tornando-se assim insolúvel e mais estável (Adriano,1986).

\subsection{A composição química da água de chuva}

Segundo Berner \& Berner (1987), a água de chuva pode ser caracterizada como uma solução salina diluída, a concentração média de sais dissolvidos é de poucos miligramas por litro, e apresenta um pH ligeiramente ácido (4 a 6).

A composição química da chuva varia de um local para o outro e depende da região de formação continental ou marinha, do tipo de solo, dos fatores biológicos e antrópicos. As TAB. 3.8 e 3.9 apresentam a associação dos componentes químicos conforme as fontes de origem e a variação na concentração dos ions de acordo com a região continental ou marinha. Os componentes quimicos encontram-se sob a forma de aerossóis, gases e ions em solução presente na atmosfera, biosfera e litosfera.

$\mathrm{O}$ pH é o parâmetro avaliador da acidez ou alcalinidade de uma solução, na água de chuva expressa o equilibrio químico entre a água e $\circ \mathrm{CO}_{2}$, natural ou antrópico, presente na atmosfera. A reação entre $\circ \mathrm{CO}_{2}$ e a água produz sua forma ácida solúvel, o ion hidrogênio carbonato $\left(\mathrm{HCO}^{-3}\right)$. As equações 3.7 representam o equilibrio de $\mathrm{H}_{2} \mathrm{O}$ com $\mathrm{CO}_{2}$ : 


$$
\begin{aligned}
-\mathrm{CO}_{2}+\mathrm{H}_{2} \mathrm{O} \leftrightarrow \mathrm{H}_{2} \mathrm{CO}_{3} \\
\mathrm{H}_{2} \mathrm{CO}_{3} \leftrightarrow \mathrm{H}^{+}+\mathrm{HCO}_{3} \\
\mathrm{HCO}_{3}^{-} \leftrightarrow \mathrm{H}^{+}+\mathrm{CO}^{2-}{ }_{3}
\end{aligned}
$$

TABELA 3.8 - Origem e associação de componentes quimicos na água de chuva.

\begin{tabular}{ll}
\hline Origem dos componentes & \multicolumn{1}{c}{ Associação } \\
\hline Marinho & $\mathrm{Cl}-\mathrm{Na}-\mathrm{Mg}-\mathrm{SO}_{4}$ \\
Solo & $\mathrm{Al}-\mathrm{Fe}-\mathrm{Si}-\mathrm{Ca}-(\mathrm{K}, \mathrm{Mg}, \mathrm{Na})$ \\
Biológico & $\mathrm{NO}_{3}-\mathrm{NH}_{4}-\mathrm{SO}_{4}-\mathrm{K}$ \\
& $\mathrm{NO}_{3}-\mathrm{NH}_{4}-\mathrm{SO}_{4}-\mathrm{K}-\mathrm{P}-\mathrm{Ca}-$ \\
Queimada de florestas & $\mathrm{Na}-\mathrm{Mg}$ \\
Poluição industrial & $\mathrm{NO}_{3}-\mathrm{Cl}-\mathrm{SO}_{4}$ \\
Fertilizantes & $\mathrm{NO}_{3}-\mathrm{NH}_{4}-\mathrm{K}-\mathrm{PO}_{4}$ \\
\hline
\end{tabular}

Fonte - Berner \& Berner, 1987.

TABELA 3.9 - Variação da concentração dos principais componentes da água de chuva em $\mathrm{mg} \mathrm{L}^{-1}$.

\begin{tabular}{lcc}
\hline Ion & Chuva continental & Chuva costeira /marinha \\
\hline $\mathrm{Na}^{+}$ & $0,2-1,0$ & $1,0-5,0$ \\
$\mathrm{Mg}^{2+}$ & $0,05-0,5$ & $0,4-1,5$ \\
$\mathrm{~K}^{+}$ & $0,1-0,5$ & $0,2-0,6$ \\
$\mathrm{Ca}^{2+}$ & $0,2-4,0$ & $0,2-1,5$ \\
$\mathrm{NH}_{4}{ }^{+}$ & $0,1-0,5$ & $0,01-0,05$ \\
$\mathrm{PH}^{-}$ & $4-6$ & $5-6$ \\
$\mathrm{Cl}^{-}$ & $0,2-2,0$ & $1,0-10,0$ \\
$\mathrm{SO}_{4}{ }^{2-}$ & $1,0-3,0$ & $1,0-3,0$ \\
$\mathrm{NO}_{3}{ }^{-}$ & $0,4-1,3$ & $0,1-5,0$ \\
\hline
\end{tabular}

Fonte - Berner \& Berner, 1987.

Além do $\mathrm{CO}_{2}$, outros componentes atmosféricos determinam a acidez, como $\circ$ ácido sulfúrico $\left(\mathrm{H}_{2} \mathrm{SO}_{4}\right)$ e nitrico $\left(\mathrm{HNO}_{3}\right)$, os quais encontram-se dissociados em fase aquosa, isto é, sob a forma de ions de hidrônio $\left(\mathrm{H}_{3} \mathrm{O}^{+}\right)$, nitrato $\left(\mathrm{NO}^{-3}\right)$ e sulfato $\left(\mathrm{SO}_{4}^{-2}\right)$ (Mello \& Motta, 1987 apud Galvão, 1996). 
Chuva ácida é definida, mais precisamente, como uma chuva com um $\mathrm{pH}$ abaixo de 5,7 devido a reaçōes com outros gases ácidos além do $\mathrm{CO}_{2}$. A presença dos gases precursores ácidos $\mathrm{SO}_{2}, \mathrm{NO}_{2}, \mathrm{NO}$, e $\mathrm{HCl}$ na atmosfera resultam na formação ácidos sulfúrico, nitrico e hidrocloridrico na agua de chuva na nuvem (Berner \& Berner, 1987).

O dióxido de enxofre provém tanto de fontes naturais, como da decomposição de animais e vegetais onde há liberação de $\mathrm{H}_{2} \mathrm{~S}$, quanto de atividades industriais, como a queima do carvão mineral e derivados de petróleo entre outros. As equações (3.8 e 3.9) abaixo representam as reações do $\mathrm{SO}_{2} \mathrm{com}$ a água de chuva:

$$
\begin{aligned}
& >\mathrm{SO}_{4}{ }^{2-}{ }_{(\mathrm{g})}+2 \mathrm{H}_{2} \mathrm{O}_{(\mathrm{l})} \leftrightarrow \mathrm{SO}_{2} .2 \mathrm{H}_{2} \mathrm{O} \\
& \mathrm{SO}_{2} 2 \mathrm{H}_{2} \mathrm{O}_{(\mathrm{l})} \leftrightarrow \mathrm{HSO}_{3}{ }^{-}+3 \mathrm{H}^{+} \\
& \mathrm{HSO}_{3}^{-} \leftrightarrow \mathrm{H}^{+}+\mathrm{SO}_{3}^{-2} \\
& \mathrm{HSO}_{3}^{-}+\mathrm{H}_{2} \mathrm{O}_{2} \leftrightarrow \mathrm{SO}_{2} \mathrm{OOH}+\mathrm{H}_{2} \mathrm{O} \\
& \mathrm{SO}_{2} \mathrm{OOH}^{-}+\mathrm{H}^{+} \leftrightarrow \mathrm{H}_{2} \mathrm{SO}_{4 \text { (aq) }} \\
& >\mathrm{H}_{2} \mathrm{~S}_{(\mathrm{g})}+{ }^{3} / 2 \mathrm{O}_{2(\mathrm{~g})} \leftrightarrow \mathrm{H}_{2} \mathrm{O}_{(\mathrm{l})}+\mathrm{SO}_{2(\mathrm{~g})} \\
& \mathrm{SO}_{2(\mathrm{~g})}+\mathrm{H}_{2} \mathrm{O}_{(\mathrm{l})} \leftrightarrow \mathrm{H}_{2} \mathrm{SO}_{3(\mathrm{aq})} \\
& 2 \mathrm{SO}_{2(\mathrm{~g})}+\mathrm{O}_{2(\mathrm{~g})} \leftrightarrow 2 \mathrm{SO}_{3(\mathrm{~g})} \\
& \mathrm{SO}_{3(\mathrm{~g})}+\mathrm{H}_{2} \mathrm{O}_{(!)} \leftrightarrow \mathrm{H}_{2} \mathrm{SO}_{4(\mathrm{aq})}
\end{aligned}
$$

Do mesmo modo que o dióxido de enxofre, os óxidos de nitrogênio estão presentes naturalmente na atmosfera devido a atividades animais, vegetais, bactérias do solo, bem como devido a atividades antrópicas.

O NO presente na atmosfera é facilmente oxidado para $\mathrm{NO}_{2}$, que por sua vez, irá reagir com a água de chuva gerando os ácidos $\mathrm{HNO}_{3}$ e $\mathrm{HNO}_{2}$, este último também se oxida para $\mathrm{HNO}_{3}$, segundo as equação 3.10 :

$$
\begin{aligned}
& 2 \mathrm{NO}_{(\mathrm{g})}+\mathrm{O}_{2(\mathrm{~g})} \rightarrow 2 \mathrm{NO}_{2(\mathrm{~g})} \\
& 2 \mathrm{NO}_{2(\mathrm{~g})}+\mathrm{H}_{2} \mathrm{O}_{(\mathrm{l})} \rightarrow \mathrm{HNO}_{2(\mathrm{aq})}+\mathrm{HNO}_{3(\mathrm{aq})} \\
& 2 \mathrm{HNO}_{2(\mathrm{aq})}+\mathrm{O}_{2(\mathrm{~g})} \rightarrow 2 \mathrm{HNO}_{3(\mathrm{aq})}
\end{aligned}
$$

Um estudo realizado por Fornaro \& Gutz (2001) na regiāo da grande Sāo Paulo, no periodo de 28/fevereiro e 4/outubro de 2000, em amostras de 
chuva, demonstrou que o valor de $\mathrm{pH}$ médio ponderado pelo volume (MPV) foi de 4.77, e as concentrações (MPV) dos ânions em ordem decrescente foram 28.2, $17.6,17.0,8.9$ e $6.1 \mu \mathrm{mol} / \mathrm{L}$ para $\mathrm{NO}_{3}^{-}, \mathrm{SO}^{2-}, \mathrm{HCOO}^{-}, \mathrm{CH}_{3} \mathrm{COO}^{-}$e $\mathrm{Cl}^{-}$, respectivamente. Considerando por hipótese $\mathrm{H}^{+}$como contra-ion desses ânions, a contribuição relativa para a acidez potencial seria de $29.1 \%$ para sulfato, $26.2 \%$ para formiato, $23.9 \%$ para nitrato, $13.6 \%$ para acetato e $7.2 \%$ para cloreto. As prováveis fontes dos ácidos acético e fórmico são a emissão veicular direta $e$ produção fotoquímica, incluindo oxidação do formaldeído pelo radical $\mathrm{OH}^{-}$em fase aquosa.

De 1998 à 2000, nas cidades de Cunha e São Paulo, Bourotte (2002) caracterizou os poluentes atmosféricos e a sua influência na composição da chuva. Em Cunha, onde a floresta da mata Atlântica é predominante, sugere-se que as emissões biogênicas, fontes de ácidos orgânicos, e as queimas de biomassa, emitem $\mathrm{NO}_{x}$ na atmosfera, onde se transforma em $\mathrm{NO}_{3}$, são a origem da acidez da chuva. Em oposição, na área urbana, intensamente industrializada, a acidez da chuva é principalmente oriunda de fontes antrópicas, pois sulfatos e nitratos predominam. É reconhecido um enriquecimento em ânions $\mathrm{NO}_{3}{ }^{-} \mathrm{e} \mathrm{SO}_{4}{ }^{2-}$, que reagem com a água produzindo os ácidos $\mathrm{HNO}_{3}$ e $\mathrm{H}_{2} \mathrm{SO}_{4}$, que abaixam o pH da chuva.

Em São Paulo, Galvão (1996) pesquisou a chuva ácida na cidade universitária, e apresentou uma hierarquia iônica entre os principais ions da chuva. Em relação aos ânions, a ordem crescente é: $\mathrm{Cl}^{-}, \mathrm{NO}_{3}{ }^{-}$e $\mathrm{SO}_{4}{ }^{2-}$.

Estes estudos evidenciam que os dois principais agentes responsáveis pela acidez da chuva em São Paulo são os ânions $\mathrm{NO}_{3}{ }^{\circ}$ e $\mathrm{SO}_{4}{ }^{2-}$.

A chuva ácida é capaz de lixiviar metais presentes em ligas, solos e rochas, uma vez que os íons $\mathrm{H}+$ da precipitação ácida agem como receptores dos elétrons liberados pelos metais. Esses metais podem ser tóxicos, causando efeitos indesejáveis ao meio ambiente e à saúde. 


\section{MATERIAIS E MÉTODOS}

\subsection{Coleta das colunas de solo e contexto Geológico}

A região de coleta do solo utilizado no presente projeto localiza-se no município de Suzano, sub-região leste da região metropolitana de São Paulo, na latitude de $23^{\circ} 32^{\prime} 15^{\prime \prime}$, a $40 \mathrm{~km}$ ao sul da cidade de São Paulo (FIG. 4.1). O local foi escolhido por se tratar de uma área com solo tipo latossolo, e por já existirem trabalhos com metais tóxicos realizados na área (Mello Junior,1998; Sigolo,1998; Amarante, 1997; Dauga, 2000).

A área pesquisada encontra-se sobre o embasamento cristalino, próximo a sudeste da Bacia de São Paulo. De acordo com o mapeamento realizado por Paulo (1990), ocorrem duas suites de rochas no local, em contato gradacional ao Complexo Embu. O Complexo Embu é descrito como uma unidade com caracteristicas individualizadas com onze conjuntos litometamórficos-estruturais, metamorfismo fácies anfibolito, com grau crescente de migmatizacão.

O relevo regional é bastante acidentado, com manto de intemperismo muito desenvolvido e rocha parcial a totalmente alteradas. O relevo local apresenta relevo de degradação, constituindo de morros paralelos, com topos arredondados, com vales fechados a abertos e planicies interiores onde predominam declividades acima de 15\% (Mello Junior, 1998). 


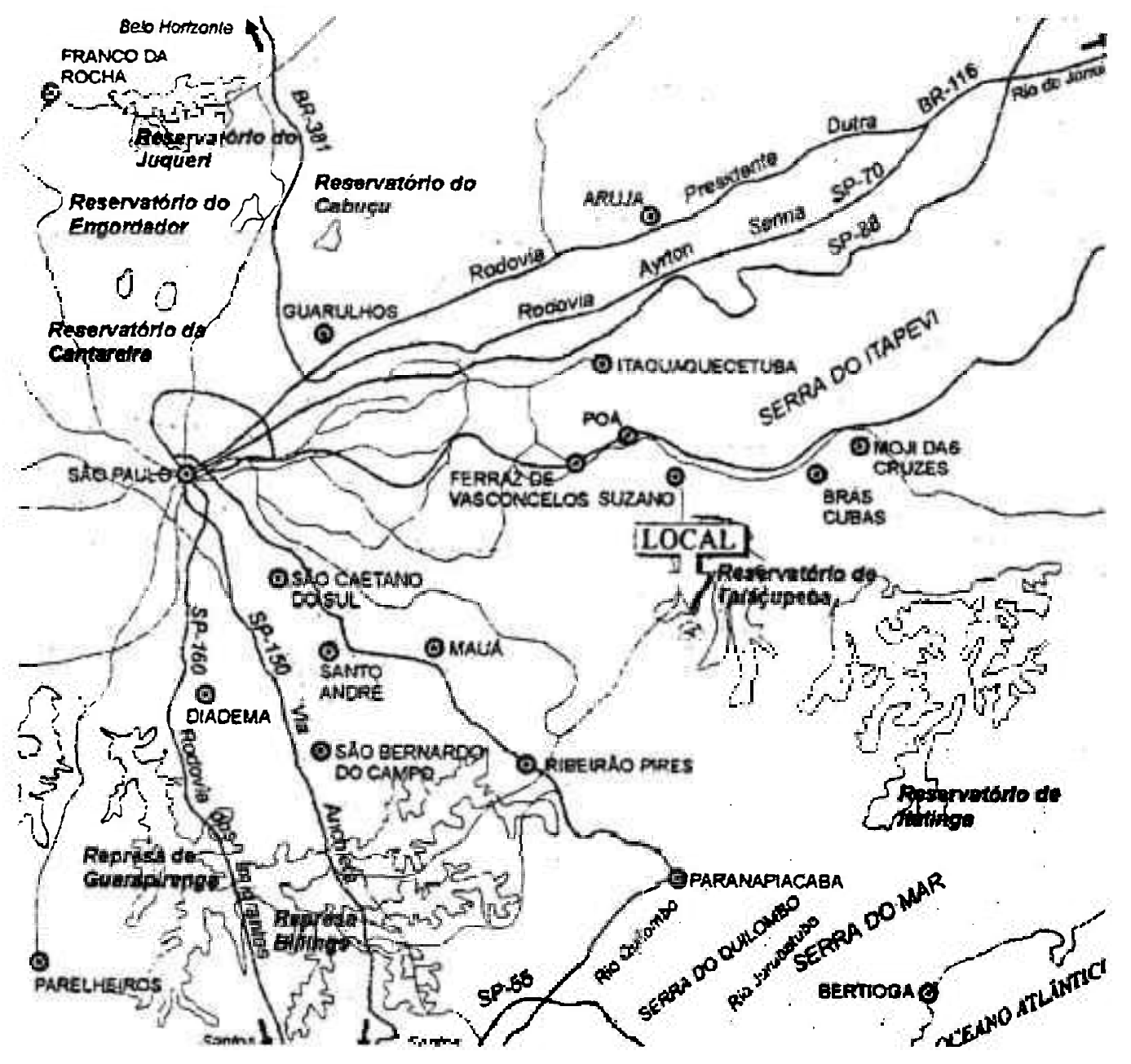

FIGURA 4.1 - Local de coleta, adaptado de Melo Junior, 1998.

A FIG. 4.2 mostra o perfil no local de coleta das amostras, as observações efetuadas até a profundidade de $150 \mathrm{~cm}$ não permitiram atingir a rocha mãe do. latossolo. De acordo com Dauga (2000), a descrição do perfil conforme seus horizontes é:

- Horizonte A; orgânico, argilo-húmico de superficie, espesso de $25 \mathrm{~cm}$ aproximadamente, é escuro, muito rico em raízes e sua estrutura é nitidamente grumulosa.

- Horizonte B; subjacente possui espessura compreendida entre 80 e 100 $\mathrm{cm}$. Trata-se de um horizonte muito argiloso, bruno-ocre na superficie, tornandose cada vez mais amarelo, em direção à sua base. A estrutura é bem mais microagregada que aquela apresentada no horizonte anterior e sua porosidade é mais fina. Neste horizonte foi observada a presença de grandes cristais de mica branca (muscovita). 
- Entre 100 e $120 \mathrm{~cm}$ de profundidade ocorre um horizonte de transição gradual solo alterita, denominado $B / C$.

- Horizonte $\mathrm{C}$; alterita, vermelho-violáceo, menos argiloso e mais poroso que os horizontes acima. É rico em cristais milimétricos de quartzo. No seu interior é comum a presença de fragmentos de rocha totalmente alterada (saprolito) com estrutura conservada.

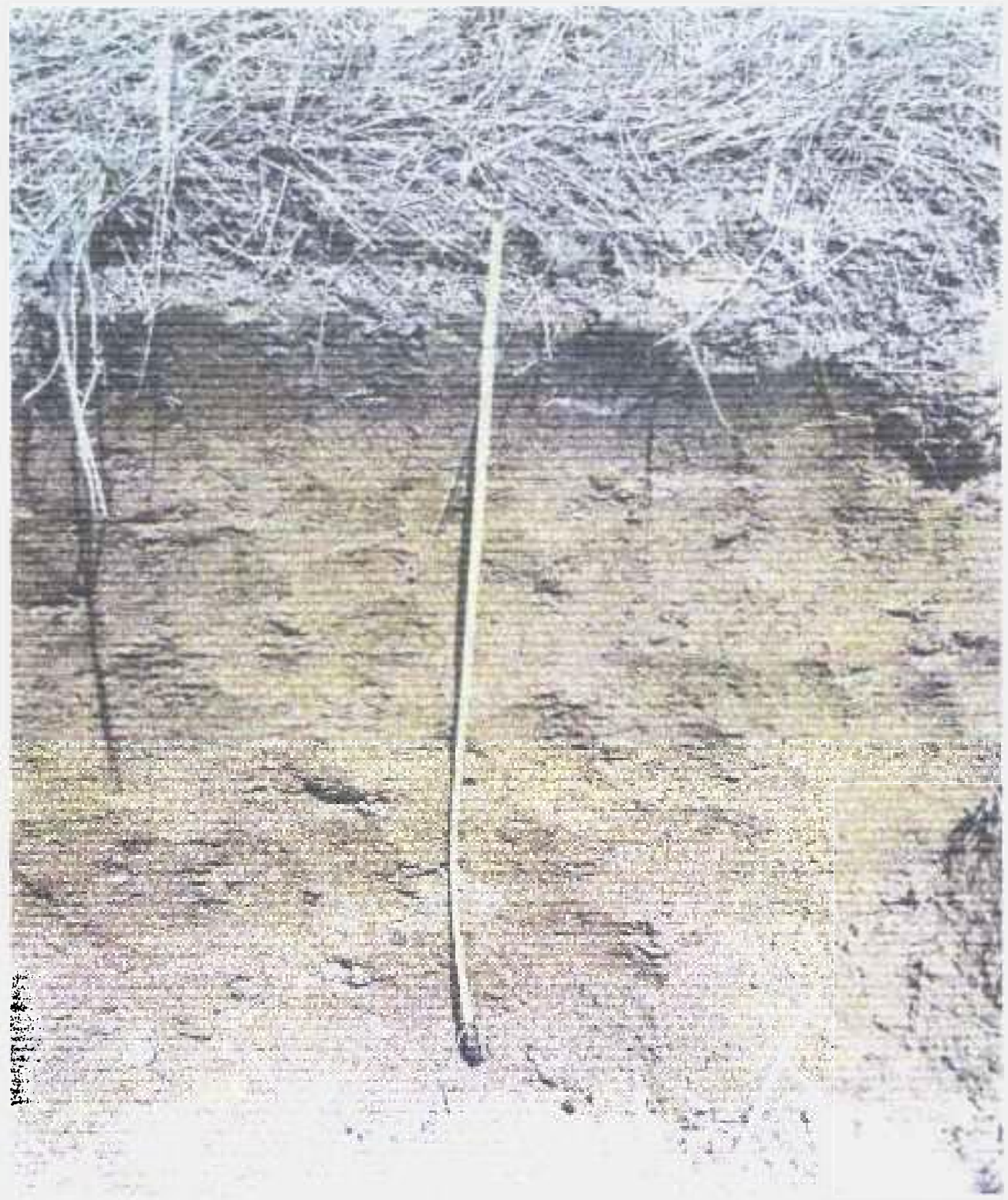

FIGURA 4.2 - Perfil do solo junto ao local de coleta das colunas de solo. 
As colunas de solo amostradas foram coletadas no alto de numa colina sob vegetação secundária, foi aberta uma trincheira junto ao solo para permitir a caracterização do solo e facilitar a retirada das colunas indeformadas. Não há no local erosão aparente.

Foi demarcada uma área de aproximadamente $1,5 \mathrm{~m}$ por $1,5 \mathrm{~m}$, de onde inicialmente foram retiradas a vegetação e parte da porção relativa ao horizonte $A$ do solo $(20 \mathrm{~cm})$, em razão da interferência que a matéria orgânica causaria nos resultados.

A seguir foi escavada uma trincheira, FIG. 4.3, com uma área um pouco menor que a citada anteriormente, com uma profundidade de $1,5 \mathrm{~m}$, de modo a comportar duas pessoas.

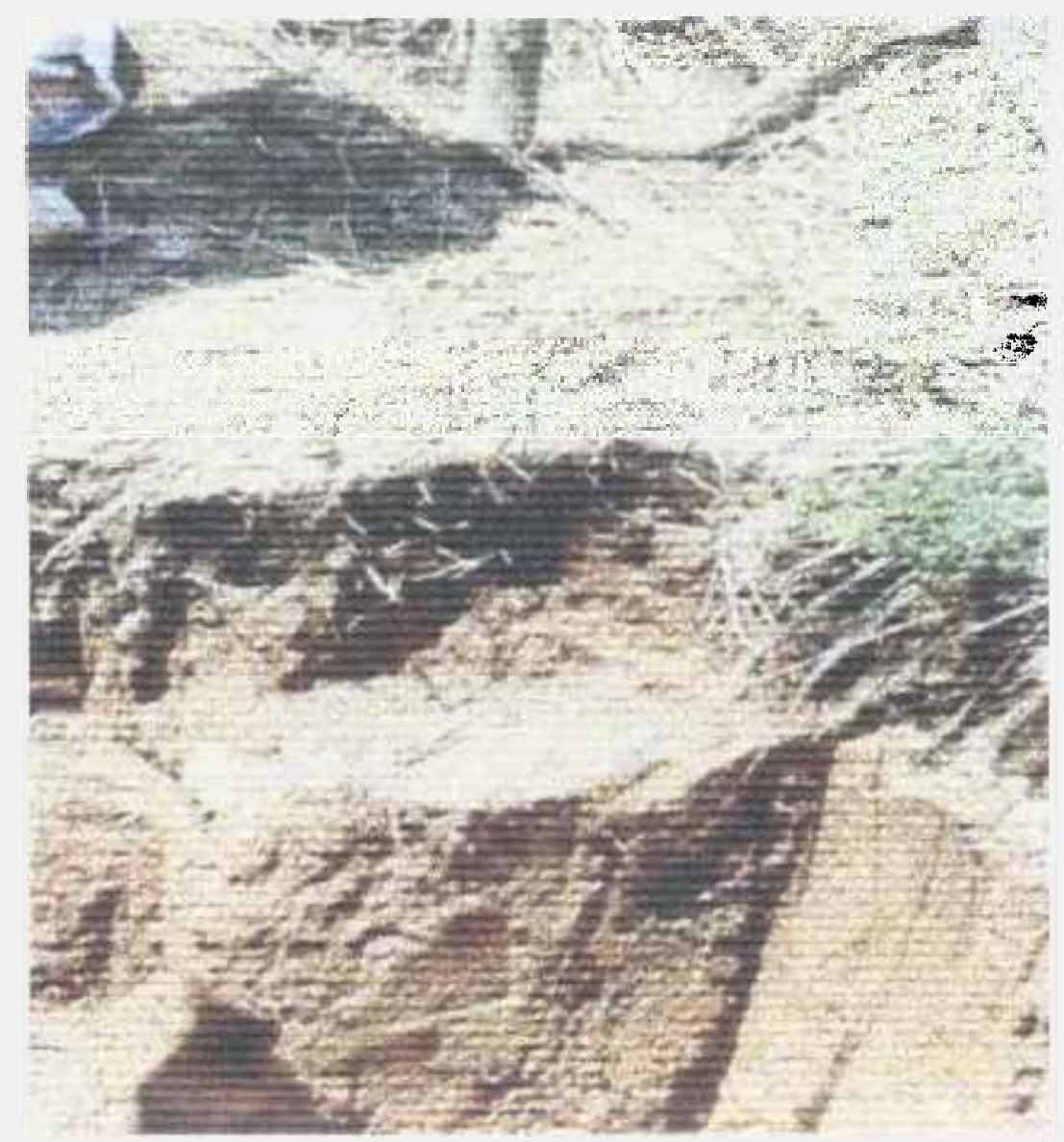

FIGURA 4.3 - Trincheira aberta para coleta das colunas. 
As colunas de solo foram retiradas junto as laterais da trincheira, aproximadamente a $20 \mathrm{~cm}$ abaixo da superficie. Nas áreas juntas as colunas, 0 excesso inicial de solo foi retirado como auxilio de uma trolha de pedreiro. A seguir, cada coluna, foi "esculpida" com um canivete até as dimensões desejadas de $0,06 \mathrm{~m}$ de diâmetro e $0,25 \mathrm{~m}$ de altura.

Depois de esculpidas, as colunas foram acondicionadas dentro de provetas de polipropileno (material inerte) de $1000 \mathrm{ml}$, esse material foi escolhido por ser translúcido e permitir a visualização interna da coluna de solo. As colunas foram seladas após a colocação para conservar a umidade do solo.

As colunas de solo amostradas são do tipo indeformadas, isto é, coletadas de forma a preservar a estrutura original do solo, portanto, a densidade do solo, a velocidade de infiltração de água, e a distribuição das frações granulométricas mantiveram-se inalteradas.

Uma das colunas de solo será mantida no estado original, sem lixiviação, para servir de comparação com as demais colunas, essa coluna será chamada de original. As quatro colunas restantes serão submetidas a uma lixiviação com uma solução simuladora de chuva.

\subsection{Caracterização do solo}

Foram coletadas amostras de solo de 0 a $60 \mathrm{~cm}$ junto ao perfil onde foram amostradas as colunas de solo. A coleta das amostras de solo foi realizada com ajuda de um canivete, retirando-se frações de solo na forma de um quadrado. de aproximadamente $8 \mathrm{~cm}$ de comprimento, $4 \mathrm{~cm}$ de largura por $6 \mathrm{~cm}$ de altura. As amostras foram coletadas em várias profundidades de 0 a $60 \mathrm{~cm}$, sendo depois acondicionadas em sacos plásticos. Essas amostras foram secas a temperatura ambiente em bandejas de aço inox, em local protegido de possiveis contaminações, como poeira e correntes de ar.

Após secas as amostras foram destorreadas num almofariz de cerâmica com a ajuda do pistilo de borracha e peneiradas em uma peneira de $2 \mathrm{~mm}$. Estas amostras de solo foram quarteadas e pesadas conforme a exigência do ensaio e armazenadas em frascos plásticos para posterior caracterização. 
Рага determinar do $\mathrm{pH}$ do solo empregam-se usualmente duas metodologias, medida de $\mathrm{pH}$ em solução aquosa ou salina. No presente trabalho foi adotada a determinação do $\mathrm{pH}$ do solo numa solução salina de $\mathrm{KCl} 1 \mathrm{~mol}^{-1}$ com proporção solo: solução 1:2,5 (EMBRAPA, 1997).

$\mathrm{O} \mathrm{pH}$ medido em solução $\mathrm{KCl}$ reflete uma mobilização da acidez potencial devida às trocas entre o potássio e os cátions de $\mathrm{Al}^{3+} \mathrm{e}^{3} \mathrm{ou} \mathrm{H}^{+}$do solo. Este método apresenta, contudo, algumas vantagens importantes com relação à determinação em água. A determinação em $\mathrm{KCl}$ praticamente apresenta os mesmos valores, quer feita no líquido sobrenadante, quer na suspensão ou no sedimento. Por outro lado, os resultados são menos afetados pela variação da concentração de outros sais presentes no solo. Em decorrência disso, o pH em $\mathrm{KCl}$ oferece resultados mais confiáveis (Moniz, 1972).

$O$ termo acidez potencial ou de reserva refere-se aos ions $H$ permutáveis retidos nos colóides do solo, enquanto que o termo acidez ativa é utilizado para identificar a concentração de íons $\mathrm{H}$ da solução do solo. Portanto a determinação em água reproduz somente a acidez ativa, enquanto que a determinação salina reproduz a acidez ativa e acidez potencial (EMBRAPA, 1999).

A metodologia em $\mathrm{KCl}$ é muito simples, transferir $10 \mathrm{~g}$ de solo para um béquer de $50 \mathrm{ml}$; adicionar $25 \mathrm{ml}$ de $\mathrm{KCl} 1 \mathrm{~mol} \mathrm{~L}^{-1}$, a seguir agitar a solução mecanicamente durante quinze minutos, esperar no minimo trinta minutos para atingir o equilibrio e proceder a leitura. A equação da reação deste método pode ser simplificada da seguinte maneira:

$$
>\text { Solo- } \mathrm{H}^{+}+\mathrm{KCl}=\mathrm{H}^{+}+\mathrm{Cl}^{-}+\text {Solo- } \mathrm{K}
$$

$\mathrm{O}$ equipamento utilizado para a leitura do $\mathrm{pH}$ foi o Multi Line $\mathrm{P} 3 \mathrm{pH} / \mathrm{Oxi}-$ SET da WTW.

\section{Determinação granulométrica}

A metodologia adotada para a caracterização granulometrica do solo segue o método de densimetro de Boyoucos (Klute, 1986). As determinaçōes são feitas através da densimetria das suspensões de solo selecionadas em diferentes tempos.

Colocar uma amostra de $50 \mathrm{~g}$ de solo num erlenmeyer de $500 \mathrm{ml}$, adicionar $250 \mathrm{ml}$ de dispersante $(4 \mathrm{~g}$ de hidróxido de sódio e $10 \mathrm{~g}$ de 
hexametafosfato de sódio dissolvidos em um litro de água destilada). Agitar a solução formada durante 16 horas no agitador horizontal tipo "shaker" a $170 \mathrm{rpm}$.

$A$ adição do dispersante tem por finalidade destruir os agregados do solo, separando-os em partículas individualizadas e que devem permanecer em suspensão estável durante toda a marcha analítica. Essa fase é constituída de duas partes: separação das partículas unitárias e estabilização da suspensão (Moniz, 1972).

Transferir a solução para uma proveta de $1000 \mathrm{~mL}$ e completar com água destilada até $1000 \mathrm{~mL}$. Preparar uma solução "branco" numa proveta de $1000 \mathrm{~mL}$ com $250 \mathrm{~mL}$ do dispersante quimico acrescentando água até completar $1000 \mathrm{~mL}$. Verificar a temperatura e a densidade da solução branco com o densímetro de Boyoucos (densímetro fornece a quantidade de argila e silte em gramas).

Agitar a solução dispersante + solo utilizando um êmbolo, através de movimentos lentos, para cima e para baixo, para que a solução fique homogênea. Imediatamente após a agitação, iniciar a contagem do tempo com o cronômetro e fazer leitura com densimetro a 40 s. Em seguida, deixar a solução em repouso durante $2 \mathrm{~h}$ quando será feita uma nova leitura.

A velocidade com que as particulas irão se depositar no fundo da proveta irá depender do seu tamanho e peso (Lei de Stock), deste modo, as mais pesadas como a areia irão se depositar rapidamente, o silte deposita-se em duas horas e a argila fica suspensa por mais tempo (FIG. 4.4).

Para calcular a porcentagem de argila, silte e areia são aplicadas as equaçōes 4.1, 4.2 e 4.3:

$$
\begin{aligned}
& >\% \text { argila }=\frac{\text { leitura } 2 \mathrm{~h} \text { - leitura do branco }}{50} \\
& >\% \text { silte }=\frac{\text { leitura } 40 \mathrm{~s}-\text { leitura } 2 \mathrm{~h}}{50} \\
& >\% \text { areia total }=100-(\% \text { argila }+\% \text { silte })
\end{aligned}
$$




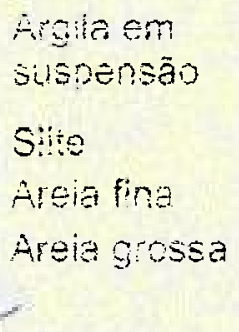

FIGURA 4.4-Decantação do solo e as diferentes granulometrias do solo.

\section{Determinação da capacidade de troca catiônica (CTC)}

$O$ método por $\mathrm{BaCl}_{2}$ permite a determinação eficaz da capacidade de troca cationica (CTC) em vários tipos do solo. Este método de CTC é calculado como base da soma da troca dos cátions $\mathrm{Ca}, \mathrm{Mg}, \mathrm{K}, \mathrm{Al}, \mathrm{Fe}$, e Mn (Carter, 1993).

O método utiliza $\circ \mathrm{Ba}^{2+}$ como ín adequado para solos com matéria orgânica. O procedimento consiste em saturar a amostra de solo com o cátion $\mathrm{Ba}^{2+}$ realizando em seguida a sua troca por $\mathrm{Mg}^{2+}$. $\mathrm{O} \mathrm{Mg}^{2+}$ excedente é quantificado por titulação com solução EDTA.

A determinaçäo segue o seguinte o procedimento sugerido por Gilmann (1979): pesar $1 \mathrm{~g}$ de solo num tubo centrifuga de $50 \mathrm{~mL}$. Adicionar $40 \mathrm{~mL}$ da solução tampão 1:1 de TEA (trietanolamina) $0,34 \mathrm{~mol} \mathrm{~L}^{-1}$ e $\mathrm{BaCl}_{2} 1 \mathrm{~mol} \mathrm{~L}^{-1}$; e agitar por 16 horas a 170 rpm num agitar mecânico horizontal tipo "shaker". Após o período de 16 horas, centrifugar a amostra a 3000 rpm por aproximadamente 10 minutos, descartar o líquido sobrenadante. Adicionar $40 \mathrm{~mL}$ de $\mathrm{H}_{2} \mathrm{O}$ deionizada na amostra, e agitar o suficiente para lavar a amostra completamente, aproximadamente 10 minutos. Centrifugar e descartar novamente o sobrenadante. Adicionar $20 \mathrm{~mL}$ da solução de $\mathrm{MgSO}_{4} 0,025 \mathrm{~mol} \mathrm{~L}^{-1}$ ao tubo de centrifuga e agitar mecanicamente por 2 horas. Centrifugar e transferir o sobrenadante para um frasco fechado (extrato final), e descartar a amostra de solo do tubo. Numa alíquota de $5 \mathrm{~mL}$ do extrato final, adicionar $0,5 \mathrm{~mL}$ de uma solução tampão $\mathrm{NH}_{4} \mathrm{OH} / \mathrm{NH}_{4} \mathrm{Cl}$ pH=10, 2 gotas solução indicadora (negro de eriocromo $\mathrm{T}$ ) e titular com a solução de $\mathrm{Na}_{2}$ EDTA $0,01 \mathrm{~mol} \mathrm{~L}^{-1}$ até o ponto de 
viragem. Preparar o branco com $5 \mathrm{~mL}$ de $\mathrm{MgSO}_{4} 0,025 \mathrm{~mol} \mathrm{~L}^{-1}$ e seguir o mesmo procedimento da titulação descrita anteriormente. Para o cálculo da CTC aplicase a equação 4.4 simplificada:

$$
>C T C=8\left(V_{\text {branco }}-V_{\text {amostra }}\right)\left(\mathrm{cmol} \mathrm{kg}^{-1}\right)
$$

$V_{\text {branco }}=$ volume de EDTA gasto na titulação do branco;
$V_{\text {amostra }}=$ volume de EDTA gasto na titulação da amostra .

$O$ volume de EDTA gasto deve ser multiplicado por 8 , pois foram tomados somente $5 \mathrm{ml}$ da solução final para a titulação num total de $40 \mathrm{ml}$ de solução tampão de $\left(\mathrm{BaCl}_{2}+\mathrm{TEA}\right)$ colocados na amostra de solo para que ocorra a troca.

\section{Análise de matéria orgânica}

Os teores de matéria orgânica no solo foram quantificados pelo método Wlalkey-Black, que consiste numa oxidação da matéria orgânica por dicromato em meio ácido sulfúrico concentrado, seguida por uma titulação com $\mathrm{Fe}\left(\mathrm{NH}_{4}\right)_{2}\left(\mathrm{SO}_{4}\right)_{2}$.

Procedimento:

- Transferir $1 \mathrm{~g}$ de TFSA (Terra Fina Seca ao Ar) para erlenmeyer de $500 \mathrm{~mL}$;

- Adicionar, com uma bureta, $10 \mathrm{~mL}$ da solução de dicromato de potássio $0,167 \mathrm{~mol} \mathrm{~L}^{-1}$ e imediatamente $20 \mathrm{~mL}$ de ácido sulfúrico concentrado;

- Agitar por 1(um) minuto com uma leve rotação manual do frasco, procurando evitar que o solo adira às suas paredes;

- Deixar a suspensão em repouso por 30(trinta) minutos;

- Adicionar cerca de $200 \mathrm{~mL}$ de água destilada, $10 \mathrm{~mL}$ de ácido ortofosfórico concentrado e 8 gotas de difenilamina 1\%;

- Titular com a solução de sulfato ferroso amoniacal $0,5 \mathrm{~mol} \mathrm{~L}^{-1}$, até a viragem de azul para verde. A viragem se dá com uma gota.

- Proceder da mesma maneira com $10 \mathrm{~mL}$ de solução de dicromato, para obter o título da solução de sulfato ferroso amoniacal. Desta maneira é determinado o fator (equação 4.5), e em seguida o cálculo (equação 4.6 e 4.7). 


$$
\mathrm{MFe}=\frac{6\left(M \mathrm{Cr}_{2} \mathrm{O}_{i} \cdot V C \mathrm{Cr}_{2} \mathrm{O}_{7}\right)}{V F e}
$$

onde:

$\mathrm{M}\left(\mathrm{Cr}_{2} \mathrm{O}_{7}\right)=$ concentração molar do dicromato,

$\mathrm{V}\left(\mathrm{Cr}_{2} \mathrm{O}_{7}\right)=$ volume de dicromato,

$\mathrm{M}(\mathrm{Fe})=$ concentração molar do ferro,

$V 1=$ volume de sulfato ferroso amoniacal gasto na titulação.

Cálculo:

$$
\% \mathrm{C}=\frac{\left[6\left(\mathrm{MCr} \mathrm{O}_{2} \mathrm{O}_{3} . \mathrm{CH}_{2} \mathrm{O}_{3}\right)-1\left(\mathrm{MFe}^{\prime \prime} . \mathrm{VFe}^{r^{-}}\right]\right.}{p}, 0,004.100
$$

onde:

$\mathrm{V}_{\mathrm{Fe} 2+}=$ volume de sulfato ferroso amoniacal gasto na titulação da amostra,

$$
\begin{aligned}
& p=\text { peso da amostra, } \\
& \% \text { M.O. = \%C .1,725 }
\end{aligned}
$$

\subsection{Montagem do sistema de lixiviação}

$\mathrm{Na}$ extremidade inferior das provetas contendo as quatro colunas de solo, foram acoplados funis de vidro. O funil foi fixado com cola de silicone nas bordas externas, no interior de cada funil foram colocadas duas camadas de papel de filtro, de modo a filtrar o percolado e não permitir ao escape de partículas do solo.

Para a sustentação vertical das provetas com os funis foi utilizado suporte universal com garras. Abaixo do funil, foi colocado um frasco plástico, trocado quinzenalmente para coleta do percolado proveniente da lixiviação da solução simuladora "água de chuva", adicionada no topo da coluna de solo.

Em duas, das quatro colunas de solo, foram colocadas na parte superior, três pilhas exauridas zinco-carbono tamanho AA, marca Rayovac. As pilhas foram prensadas, para acelerar o processo de ruptura das pilhas $e$ 
possibilitar o vazamento dos metais, simulando assim uma contaminação. Essas colunas serão denominadas de contaminada, as outras duas colunas serão o branco da lixiviação. A metodologia adotada baseia-se no conceito de comparação dos dados obtidos em uma coluna contaminada em relação ao "background" local que seria a coluna branco, e estas duas colunas, por sua vez serão comparados à coluna original.

Para lixiviar as colunas de modo a simular a chuva, utilizaram-se quatro colunas cromatográficas de vidro graduadas com torneira dosadora por onde se adicionou a solução "água de chuva" conforme o volume mensal desejado. As colunas cromatográficas foram colocadas em um suporte de madeira acima das colunas de solo, para facilitar o escoamento da solução "água de chuva" pelas mangueiras.

A cada coluna cromatográfica conectou-se uma mangueira que foi transpassada horizontalmente no topo da coluna de solo. A ponta da mangueira inserida na coluna foi perfurada, permitindo que a solução "água de chuva" fosse adicionada lentamente à coluna de solo.

A FIG. 4.5 apresenta o sistema de lixiviação, as colunas de solo foram colocadas em paralelo com as colunas cromatográficas para facilitar a visualização do sistema todo na figura. Observa-se nas colunas centrais, no topo da coluna logo acima do solo, um resíduo negro referente às pilhas. As colunas laterais correspondem às colunas branco.

\subsection{Solução simuladora de "água de chuva"}

Para a lixiviação das colunas, simulou-se uma solução de chuva ácida com base no $\mathrm{pH}$ e nos principais ânions encontrados na literatura, conforme descrito no item 3.4. Estudo realizado por Fornaro \& Gutz (2001) para as chuvas da grande São Paulo, observou valor de $\mathrm{pH}$ médio de 4.77, e o ânions mais comuns foram $\mathrm{NO}_{3}^{-}, \mathrm{SO}_{4}^{2-}, \mathrm{HCOO}^{-}, \mathrm{CH}_{3} \mathrm{COO}^{-}$. Os anions $\mathrm{NO}_{3}^{-}, \mathrm{SO}_{4}^{2-}$ são principais contribuintes poluidores geradores da chuva ácida. Dentro deste contexto preparou-se uma solução simuladora de chuva ácida na proporção 1:1 dos ácidos $\mathrm{HNO}_{3}$ e $\mathrm{H}_{2} \mathrm{SO}_{4}$ a $\mathrm{pH} 4$, que será denominada de "água de chuva":

"Água de chuva": $\mathrm{pH} 4,0$ e ânions $\mathrm{NO}_{3}^{-}{\text {e } \mathrm{SO}^{2-}}_{4}$. 


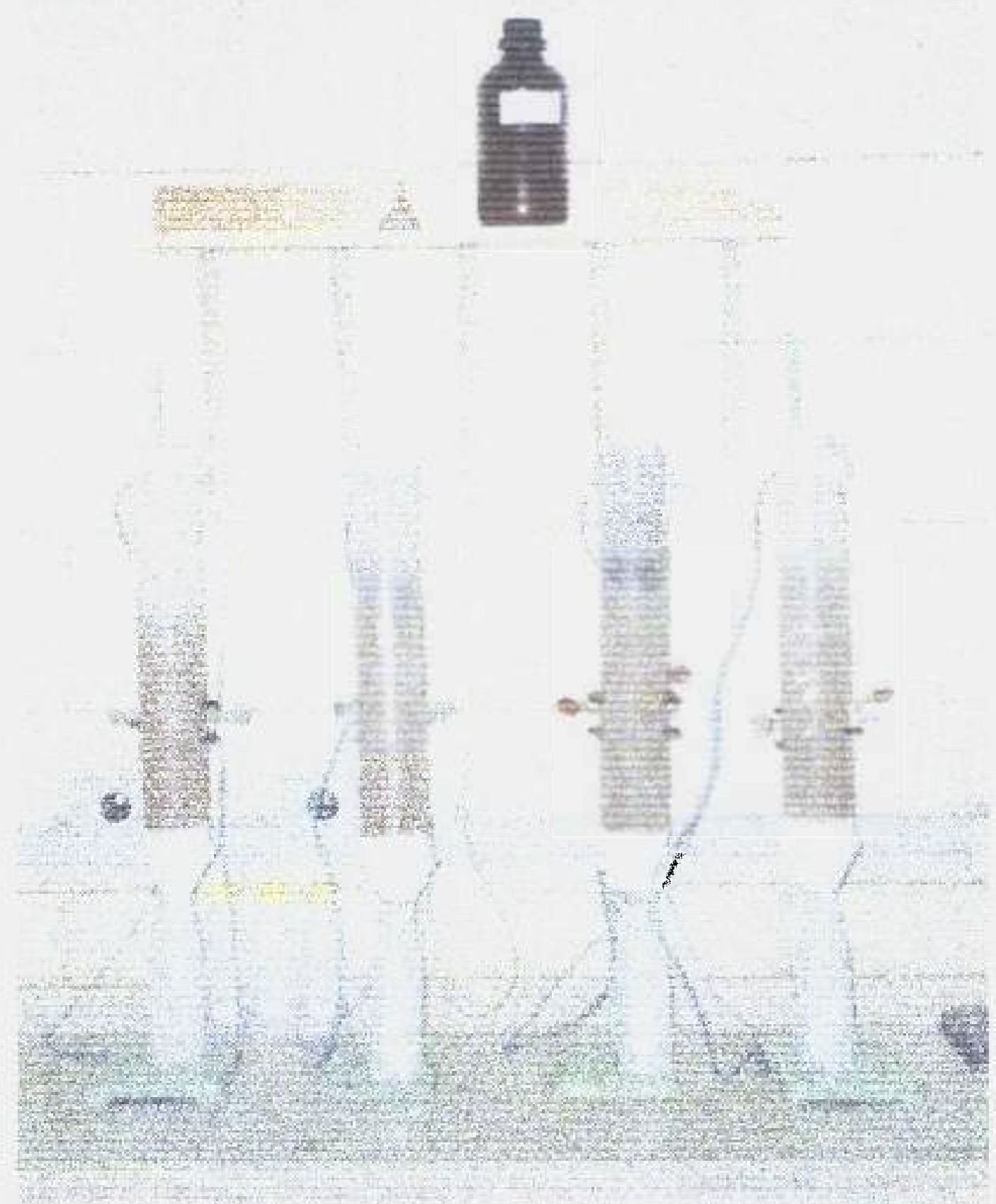

FIGURA 4.5 - Sistema de lixiviação das colunas de solo contaminadas por pilhas (colunas centrais) e branco (colunas laterais).

*as colunas de solo foram levantas do suporte inferior para facilitar o enquadramento da foto. 
As três pilhas zinco-carbono foram seccionadas manualmente, e a pasta interna que representa $40 \%$ da massa da pilha (Hinrichs \& Soares, 2001) mais o copo de zinco foram lixiviados em um erlenmeyer de $500 \mathrm{~mL}$ com $250 \mathrm{~mL}$ da solução "água de chuva" durante 24 horas em um agitador mecânico horizontal tipo "shaker". Na solução obtida, foram analisadas as concentrações dos metais $\mathrm{Mn}, \mathrm{Zn}, \mathrm{Ni}, \mathrm{Cd}, \mathrm{Cr}, \mathrm{Cu}$ e $\mathrm{Pb}$ pela técnica ICP-OES no Laboratório de Espectrometria de Emissão Atômica do IQ-USP.

\subsection{Lixiviação das colunas}

Quatro colunas de solo coletadas foram lixiviadas com a solução "ägua de chuva". Uma coluna branco e uma coluna contaminada foram lixiviadas durante seis meses, com volumes relativos de chuva dos meses de junho a novembro, abrangendo assim o periodo de seca e o começo da estação chuvosa. As outras duas colunas, também uma branco e outra contaminada, foram lixiviadas durante um ano.

Para estabelecer o volume de chuva relativo a cada mês do ano foi utilizado a média da precipitação mensal de chuva em $\mathrm{mm}$ dos últimos 70 anos da grande São Paulo, conforme os dados obtidos através do site do Instituto de Meteorologia - INMET (FIG 4.6).

A escolha do periodo de 1931-2000 visa abranger periodos tanto de seca como de maior pluviosidade ao longo dos anos, tornando assim a média mais confiável.

Como a precipitação é a altura que a chuva alcança numa área de 1 m2, a quantidade a ser adicionada a coluna de solo deverá obedecer a área desta última. Para calcularmos o volume a ser adicionado de solução "água de chuva", a média de cada mês foi multiplicada pela área da coluna, 0,0028 $\mathrm{m} 2$, e depois transformada em $\mathrm{mL}$. $O$ volume a ser adicionado nas quatro colunas de acordo com os meses é apresentado na FIG. 4.7.

A escolha do periodo de 1931-2000 visa abranger períodos tanto de seca como de maior pluviosidade ao longo dos anos, tornando assim a média mais confiável. 


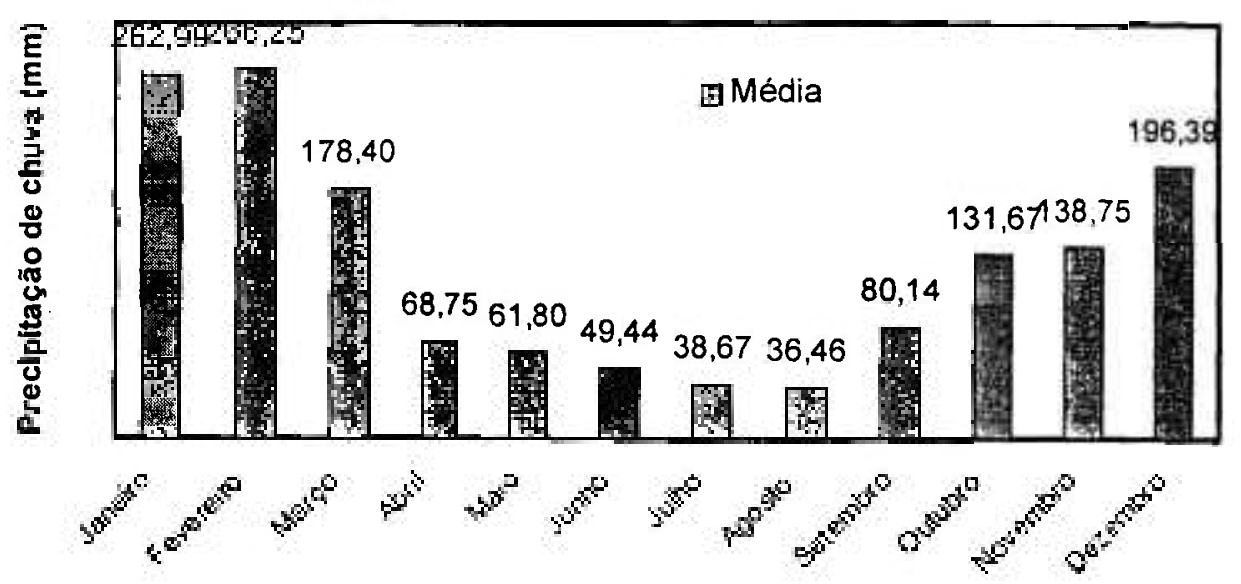

FIGURA 4.6 - Valores da precipitação mensal de chuva em mm dos últimos 70 anos conforme dados do INMET.

Como a precipitação é a altura que a chuva alcança numa área de 1 $\mathrm{m} 2$, a quantidade a ser adicionada a coluna de solo deverá obedecer a área desta última. Para calcularmos o volume a ser adicionado de solução "água de chuva", a média de cada mês foi multiplicada pela área da coluna, 0,0028 $\mathrm{m} 2$, e depois transformada em $\mathrm{mL}$. $\mathrm{O}$ volume a ser adicionado nas quatro colunas de acordo com os meses é apresentado na FIG. 4.7.

Os efluentes gerados pela percolação da solução "água de chuva" nas quatro colunas de solo foram coletados mensalmente e o seu volume foi anotado. Os parâmetros físicos-quimicos, como $\mathrm{pH}$, Eh e condutividade elétrica foram medidos, o aparelho utilizado foi Multi Line P3 pH/Oxi-SET e P3 pH/LF da WTW, após essas medidas o efluente foi acidulado com ácido nitrico a pH 2, filtrados em filtro milipore (45 microns), sendo mantido sob refrigeração a $-12 .{ }^{\circ} \mathrm{C}$, para conservação das amostras. A concentração dos metais $\mathrm{Zn}, \mathrm{Mn}, \mathrm{Pb}, \mathrm{Ni}$ e $\mathrm{Cd}$ nos efluentes foram analisados pela técnica ICP-OES. 


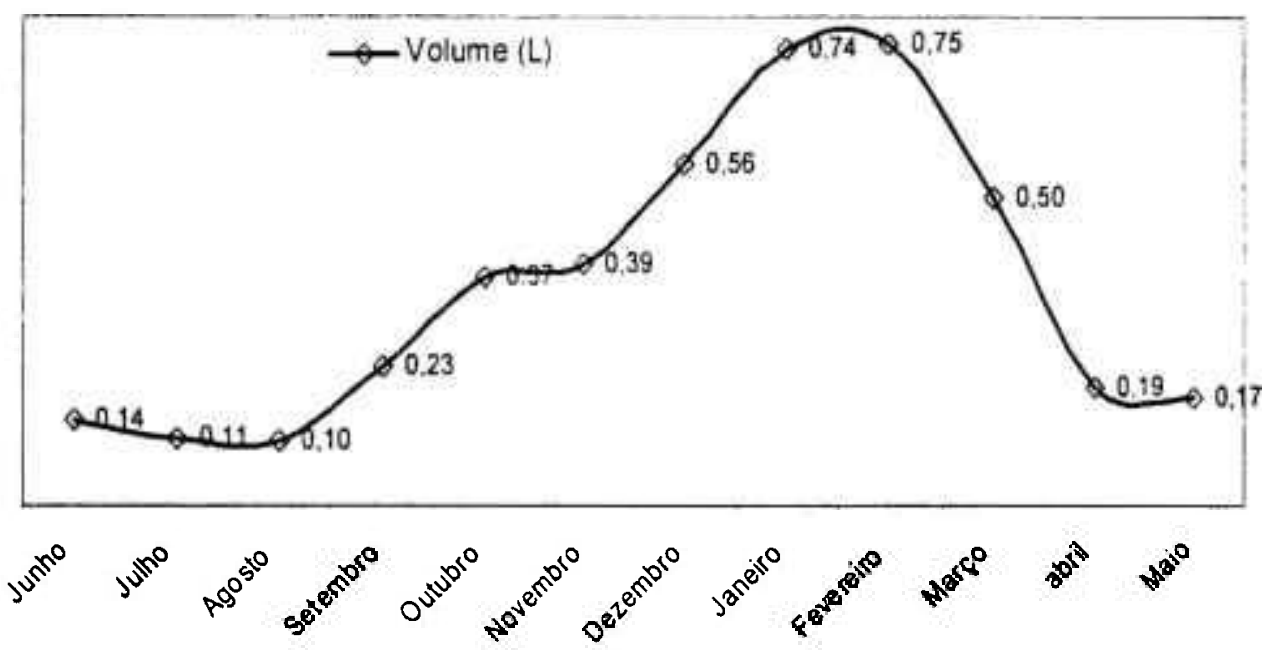

FIGURA 4.7 - Volume mensal de "água de chuva" (L) a ser adicionado as quatro colunas de solo.

\subsection{Abertura das colunas}

Após o encerramento do periodo de lixiviação correspondente (6 meses e 1 ano), as quatro colunas de solo foram congeladas com o objetivo de facilitar o corte das colunas em fraçōes. As colunas lixiviadas mais a coluna original foram seccionadas em três partes: fração de $0-5 \mathrm{~cm}$ (superior), $5-15 \mathrm{~cm}$ (média) e 15-25 cm (inferior).

As superficies das fraçōes que entraram em contado com a serra foram lixadas levemente, ainda congeladas, com uma lixa de plástico para evitar contaminar a amostra com os metais presentes na liga da serra. A parte superior das colunas contaminadas em contato com as pilhas também foram lixadas, para que apenas os metais que tivessem infiltrados no solo fossem analisados.

As frações de solo obtidas foram secas, destorreadas, e cuidadosamente homogeneizadas. As amostras de solo para as determinações da concentração parcial e biodisponivel de metais foram obtidas por quarteamento para garantir a representatividade da amostra.

Para a determinação da concentração parcial: pesar $0,5 \mathrm{~g}$ de solo tratar com $10 \mathrm{~mL}$ de $\mathrm{HNO} 3$ concentrado no forno de microondas deixar 2 minutos a 330 
$\mathrm{W}, 6$ minutos a $800 \mathrm{~W}$ e, 5 minutos a $0 \mathrm{~W}$. Depois diluir para $50 \mathrm{~mL}$, centrifugar, filtrar conforme a metodologia EPA-3051 (Hewitt \& Reynolds, 1990). A concentração dos metais $\mathrm{Mn}, \mathrm{Zn}, \mathrm{Ni}, \mathrm{Cd}$ e $\mathrm{Pb}$ foi analisada pela técnica ICP-OES no Laboratório de Espectrometria de Emissão Atômica do IQ-USP.

Para a determinação da concentração biodisponivel foi adotada a metodologia estabelecida por Ure (1996). Pesar $2 \mathrm{~g}$ de solo e adicionar $40 \mathrm{~mL}$ de EDTA-NH4 0,05 mol L-1 a pH=7. Extrair o metal do solo por agitação durante $1 \mathrm{~h}$ a $10 \mathrm{rpm}$, e depois centrifugar e filtrar a solução. A concentração dos metais $\mathrm{Mn}$, $\mathrm{Zn}, \mathrm{Ni}, \mathrm{Cd}$ e $\mathrm{Pb}$ foi analisada por ICP-OES no Laboratório de Espectrometria de Emissão Atômica do IQ-USP.

Determinação da concentração parcial dos metais no solo extrai o metal com ácidos fortes, a quente, sob pressão e estima a concentração do metal do solo que podem vir a ser potencialmente tóxicos ou contaminantes ao meio ambiente. $A$ determinação da concentração biodisponivel extrai o metal com uma solução de EDTA e esta concentração simula a concentração do metal do solo que pode ser absorvido pela plantas (Yu \& Klarup,1994). 


\section{RESULTADOS E DISCUSSĀO}

Contaminações de solo ocorrem diariamente devido ao descarte inadequado de residuos tóxicos. A avaliação da possível contaminação gerada pelo descarte de pilhas ( $\mathrm{Zn} /$ carbono) diretamente sobre o solo é importante para dar suporte ao setor público no gerenciamento do descarte de residuos tóxicos.

Dentro deste contexto serão discutidos a seguir os resultados do estudo do comportamento dos metais tóxicos das pilhas numa coluna de solo lixiviadas por uma solução de simuladora de chuva ácida que será denominada "água de chuva" no periodo de 6 meses e um ano.

Para facilitar a discussão dos resultados 0 assunto será dividido em tópicos:

- Caracterização do solo: resultados da granulometria, CTC, pH e \% M.O. do solo.

- Soluçāo "áqua de chuva": concentração dos metais $\mathrm{Mn}, \mathrm{Zn}, \mathrm{Ni}, \mathrm{Cd}, \mathrm{Cr}, \mathrm{Cu}$ e $\mathrm{Pb}$ no lixivado desta.

- Efluentes das colunas: resultados do $\mathrm{pH}$, Eh, condutividade elétrica e concentração dos metais $\mathrm{Mn}, \mathrm{Zn}, \mathrm{Ni}, \mathrm{Cd}, \mathrm{Cr}, \mathrm{Cu}$ e $\mathrm{Pb}$ nos efluentes das quatro colunas lixiviadas.

- Solo das colunas: resultados da concentração parcial e biodisponivel dos metais $\mathrm{Mn}, \mathrm{Zn}, \mathrm{Ni}, \mathrm{Cd}, \mathrm{Cr}$, $\mathrm{Cu}$ e $\mathrm{Pb}$ nas frações do solo das cinco colunas.

- Solo + efluente: avaliação da contribuição das pilhas. 


\subsection{Caracterização do solo}

As amostras de solo retiradas no perfil das colunas descrita no item 4.2, foram analisadas e os resultados da granulometria (textura do solo), capacidade de troca catiônica (CTC), $\mathrm{pH}$ e porcentagem de matéria orgânica, conforme a profundidade, (entre zero e sessenta centimetros), encontram-se nas FIG. 5.1 a 5.4.

A textura média encontrada no solo foi de: $39 \pm 2 \%$ de argila, $12 \pm 2 \%$ de silte, $49 \pm 2 \%$ de areia (FIG. 5.1). O solo não apresentou variação considerável na sua textura com a profundidade do perfil de solo.

A capacidade de troca catiônica (CTC) média do solo obtida foi de 16,5 \pm $2,3 \mathrm{cmol} \mathrm{kg}^{-1}$ (FIG. 5.2). A CTC apresentou valores mais altos na camada superfícial, de 0 a $12 \mathrm{~cm}$, devido a maior concentração de matéria orgânica nessa fração (FIG. 5.4).

A CTC que relaciona a capacidade de troca catiônica nos sitios de adsorção do solo apresentou uma média de $10 \pm 2 \mathrm{cmol} \mathrm{kg}^{-1}$, caracterizando o solo com uma CTC média segundo a classificação da Agviselabs, 2005.

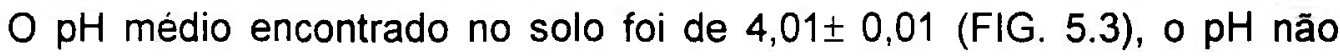
apresentou variação considerável com a profundidade. De acordo com EMBRAPA (2000) o solo foi classificado como solo ácido.

A porcentagem de matéria orgânica no solo variou entre $4,15 \%$ e 1,49\%, e a média foi $(2,49 \pm 0,01) \%$ (FIG. 5.4). A atividade biológica decresce de acordo com a profundidade do solo em razão do oxigênio, assim os valores da matéria orgânica também diminuem com a profundidade. De acordo com Brady (1989) o solo foi classificado como solo de baixa porcentagem de matéria orgânica caracterizando-o como um solo mineral. 


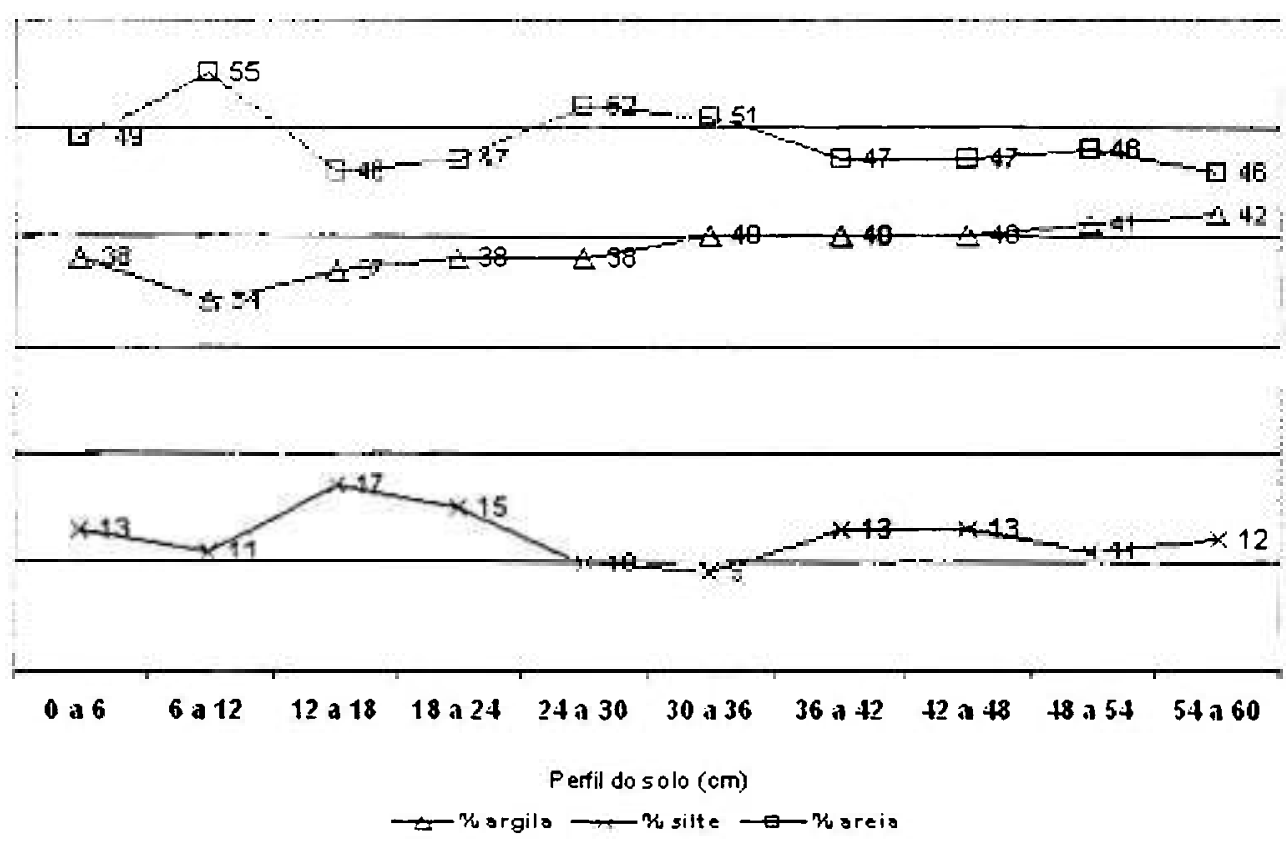

FIGURA 5.1 - Textura (\%argila, \%silte, \%areia) das amostras do perfil do solo utilizado nas colunas com a profundidade $(\mathrm{cm})$.

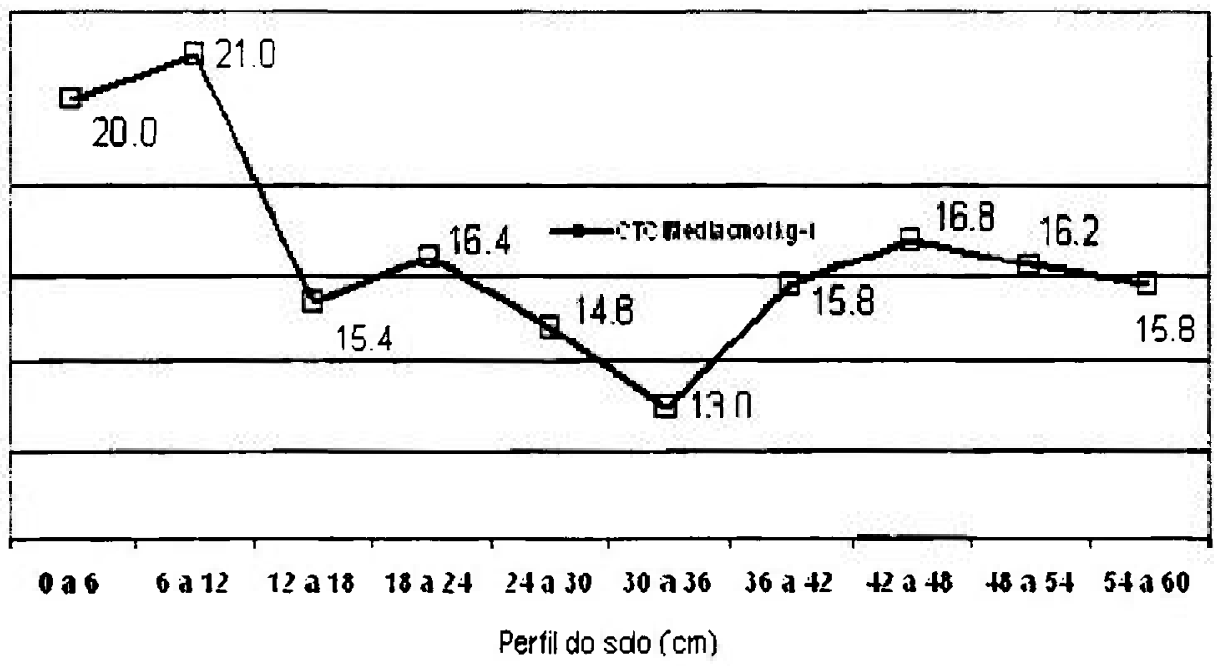

FIGURA 5.2 - Capacidade de troca catiônica (CTC) das amostras do perfil do solo utilizado nas colunas com a profundidade. 


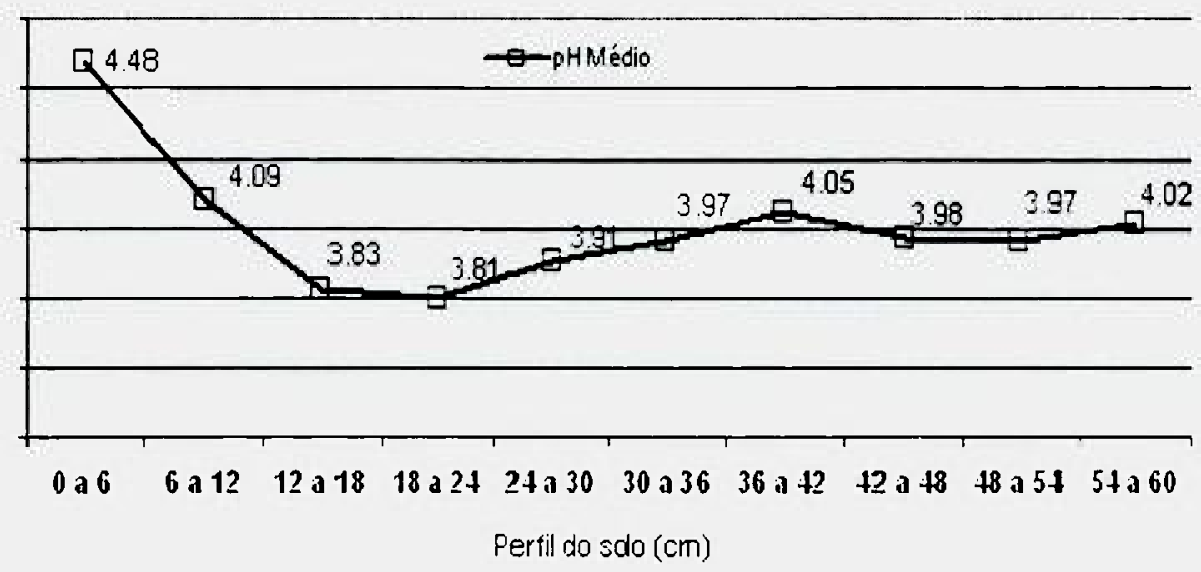

FIGURA 5.3 - Valores do pH das amostras do perfil do solo utilizado nas colunas com a profundidade.

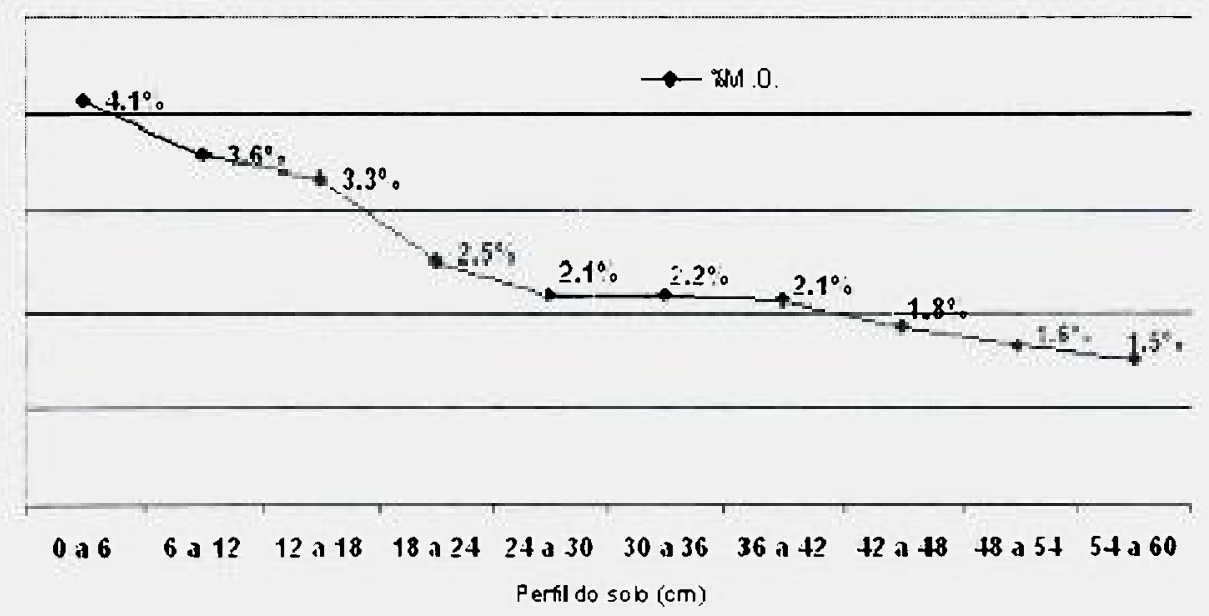

FIGURA 5.4 - Porcentagem de matéria orgânica das amostras do perfil do solo utilizado nas colunas com a profundidade.

A mineralogia desde solo foi estudada em outros trabalhos (Mello Junior,1998; Sigolo,1998; Amarante, 1997), onde foi determinada a composição mineralógica predominante: quartzo, micas (muscovita) e caulinita, ocorrendo também anfibólios/tremolita/piroxênios. 
As argilas cauliniticas têm suas camadas mais firmemente presas e permitem menos substituição de Al e Si por outros ions. Estas diferenças estruturais refletem numa menor capacidade para forças iônicas e uma menor plasticidade devida a menor capacidade de adsorver água. A caulinita, $\mathrm{AlSi}_{4} \mathrm{O}_{10}(\mathrm{OH})_{8}$, é habitualmente a argila principal dos solos de climas úmidos com soluçōes de solo ácidas e onde os cátions são eficientemente removidos. A muscovita é uma alteração da caulinita.

A caulinita apresenta a sua estrutura firmemente ligada, com hidrogênios ligados a outros átomos de hidrogênio e oxigênio nas camadas adjacentes. $A$ superficie especifica da caulinita é relativamente pequena quanto comparada com outros tipos de argila, o que deixa a sua capacidade de troca cationica menor, entre 3 e $20 \mathrm{cmol} \mathrm{kg}^{-1}$, pois a ocorrência de substituição isomórfica é muito pequena.

Apesar da textura do solo ter aproximadamente $39 \%$ de argila, o solo estudado não tem grande superficie de troca por se tratar de uma argila do tipo caulinita, isso somado a baixa porcentagem de matéria orgânica e a acidez do solo influenciam a CTC. Portanto, o solo das colunas tem capacidade média de adsorver ions, mas o pH ácido do solo e a adição de solução ácida irão facilitar a lixiviação dos ions do solo.

\subsection{Solução "água de chuva"}

A lixiviação das pilhas com uma solução "água de chuva" pH 4 (preparada conforme item 4.4) pretende simular o efeito de uma situação ambiental mais crítica. Executou-se um teste de lixiviação isolado das pilhas para avaliar a capacidade desta solução na extração dos metais da pilha.

O resultado obtido da lixiviação de 24 horas das pilhas com a solução "água de chuva" encontra-se na TAB. 5.1.

TABELA 5.1 - Concentração dos metais em $\mathrm{mg} \mathrm{L}^{-1}$ obtida da lixiviação de 3 pilhas $\mathrm{Zn}$ /carbono com a solução "água de chuva".

\begin{tabular}{cccccccc}
\hline Soluçāo & $\mathrm{Cd}$ & $\mathrm{Cr}$ & $\mathrm{Cu}$ & $\mathrm{Mn}$ & $\mathrm{Ni}$ & $\mathrm{Pb}$ & $\mathrm{Zn}$ \\
\hline "Água de chuva" ( $\left.\mathrm{mg} \mathrm{L}^{-1}\right)$ & 0,026 & 0,035 & 0,0001 & 508 & 0,313 & 0,353 & 1258 \\
\hline
\end{tabular}


A solução "água de chuva" lixiviou mais facilmente os elementos $\mathrm{Zn}$ e $\mathrm{Mn}$, que também se apresentam em maior quantidade nas pilhas. Apesar do manganês estar presente em maior quantidade na pilha, foi o zinco o elemento mais lixiviado pela soluçăo "água de chuva". A seqüência de concentração dos metais na solução "água de chuva" foi:

$$
>\mathrm{Zn}>\mathrm{Mn}>\mathrm{Pb}>\mathrm{Ni}>\mathrm{Cr}>\mathrm{Cd}>\mathrm{Cu} \text {. }
$$

Como descrito anteriormente no item 3.1, a provável reação que ocorre durante o processo de descarga de uma pilha é representado pela equação 3.3. De acordo com Bartolozzi,1994, a pilha depois de exaurida pode ainda conter $30 \%$ de Zn na sua composição, mostrando que não ocorre uma reação de oxi-reduçāo total. Analisando a reação da equação 3.3 pode-se supor que a pilha exaurida apresenta na sua composição zinco e manganês nas duas formas, oxidada e reduzida, além do eletrólito ácido que consta de uma pasta de $\mathrm{NH}_{4} \mathrm{Cl}$ e $\mathrm{ZnCl}_{2}$. Durante a descarga da pilha podem ocorrer também reações intermediárias que formam espécies solúveis como $\mathrm{Zn}\left(\mathrm{NH}_{3}\right)_{2} \mathrm{Cl}_{2}$ e $\mathrm{ZnCl}{ }_{2} .4 \mathrm{Zn}(\mathrm{OH})_{2}$ (Dell, 2000). A pilha exaurida aberta foi lixiviada com a solução "água de chuva", e as seguintes reações (equações 5.1 a 5.4 ) podem ocorrer:

$$
\begin{aligned}
& =\mathrm{ZnO}+2 \mathrm{H}^{+} \rightarrow \mathrm{Zn}_{2}^{+}+\mathrm{H}_{2} \mathrm{O} \\
& >\mathrm{ZnO}+2 \mathrm{H}^{+} \rightarrow \mathrm{Zn}_{2}^{+}+\mathrm{H}_{2} \\
& =\mathrm{Mn}_{2} \mathrm{O}_{3}+2 \mathrm{H}^{+} \rightarrow \mathrm{Mn}^{2+}+\mathrm{MnO}_{2}+\mathrm{H}_{2} \mathrm{O} \\
& >\mathrm{MnO}_{2}+2 \mathrm{H}^{+}+\mathrm{H}_{2} \mathrm{O}_{2} \rightarrow \mathrm{Mn}_{2}^{+}+2 \mathrm{H}_{2} \mathrm{O}+\mathrm{O}_{2}
\end{aligned}
$$

As reações acima apresentadas mostram que zinco e manganês inicialmente presentes na pilha tendem preferencialmente a formar cátions bivalentes tanto de $\mathrm{Zn}^{2+}$ quanto de $\mathrm{Mn}^{2+}$. A solução resultante da lixiviação das pilhas irá infiltrar na coluna de solo. Esta solução provavelmente contém $\mathrm{NH}_{4} \mathrm{Cl}$ e $\mathrm{ZnCl}_{2}$ da pasta eletrolítica. $\mathrm{Zn}$ e $\mathrm{Mn}$ nas seguintes espécies químicas: $\mathrm{Zn}^{\circ}$ e $\mathrm{MnO}_{2}, \mathrm{Zn}^{2+}$ e $\mathrm{Mn}^{2+}$, além das espécies solúveis intermediárias como $\mathrm{Zn}\left(\mathrm{NH}_{3}\right) 2 \mathrm{Cl}_{2}$ e $\mathrm{ZnCl}_{2} .4 \mathrm{Zn}(\mathrm{OH})_{2}$. 
Provavelmente $\mathrm{ZnCl}_{2}$ é o responsável pela concentração mais elevada de $\mathrm{Zn}$ no lixiviado da pilha.

\subsection{Efluentes das colunas de solo}

Quatro colunas de solo foram lixiviadas com a solução "água de chuva" conforme a média mensal da precipitação de chuva na cidade de São Paulo relativa ao período de 1931 a 2000 (item 4.5). Duas colunas, uma branco e outra contaminada com as pilhas foram lixiviadas durante de seis meses, volume de chuva referente aos meses de junho a novembro, e as outras duas, também uma branco e outra contaminada, lixiviadas durante o periodo de um ano, de junho a maio conforme a FIG 4.7.

Os efluentes resultantes da lixiviação das colunas foram coletados mensalmente. Nestes efluentes foram medidos os seguintes parâmetros experimentais: volume, $\mathrm{pH}$, Eh e condutividade elétrica. Também foi determinada a concentração dos metais $\mathrm{Zn}, \mathrm{Mn}, \mathrm{Pb}, \mathrm{Ni}, \mathrm{Cr}$, Cd e $\mathrm{Cu}$ presentes nos efluentes pela técnica de ICP-OES.

\subsubsection{Parâmetros experimentais}

\subsubsection{Colunas Branco}

O volume dos efluentes recuperado das colunas ao final da percolação foi menor que $O$ adicionado (FIG 4.7) devido aos processos de transpiração e evapotranspiração do solo. A FIG. 5.5 apresenta os volumes recuperados das colunas branco de solo.

$\mathrm{O} \mathrm{pH}$ é um parâmetro importante a ser determinado, pois este fornece informações sobre a mobilidade dos metais no solo (McBride,1994; Alloway, 1996). $\mathrm{O} \mathrm{pH}$ do efluente das colunas branco variaram entre 5,8-4,6 para a coluna de seis meses, e 4,6 - 3,6 para a coluna de um ano (FIG. 5.6). A coluna branco de seis meses apresentou valores de $\mathrm{pH}$ mais elevados, provavelmente devido à presença de hidróxido de ferro coloidal no efluente (cor amarelada). O efluente da coluna branco de seis meses apresentou uma coloração amarelada nos três meses iniciais. 
Os demais efluentes das colunas branco e contaminada apresentaram-se incolores e limpidas.

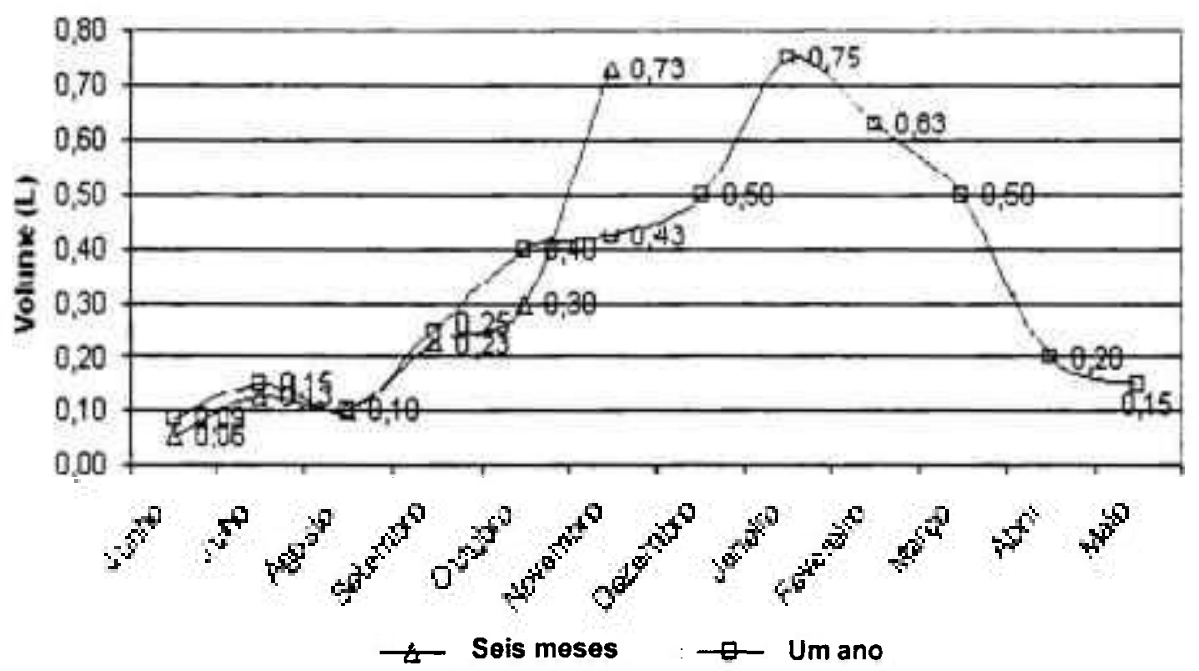

FIGURA 5.5 - Volume dos efluentes das colunas branco lixiviadas durante seis meses e um ano.

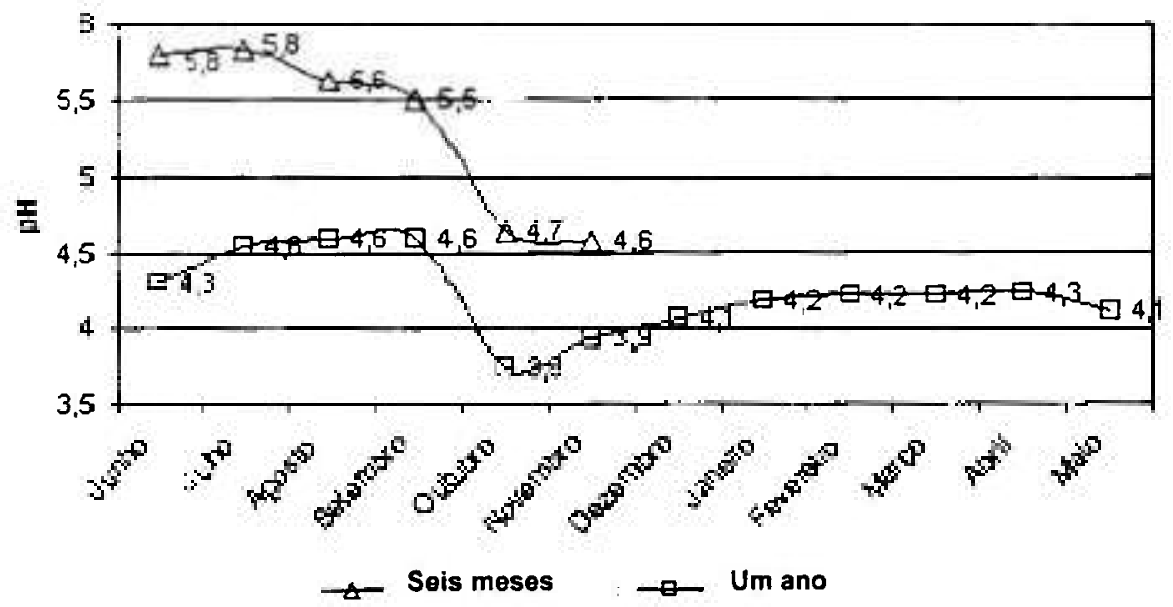

FIGURA 5.6 - Variaçāo do pH nos efluentes das colunas branco lixiviadas durante seis meses e um ano. 
Outro parâmetro importante é o redox ou potencial de óxido-redução ou simplesmente Eh. $O$ Eh do solo é influenciado pelo volume de água presente nos poros do solo, a flutuação do volume de água nos poros pode saturar o solo e conseqüentemente causar falta de oxigênio resultando em uma sucessão de reações de redox que podem alterar o $\mathrm{pH}$ do solo (McBride, 1994). Alguns metais apresentam mais de um estado de oxidação, como $\mathrm{Mn}, \mathrm{Pb}$ e $\mathrm{Cr}$ e podem ser afetados pelas reaçōes de óxido-redução no solo (Sposito, 1989).

O Eh em ambas as colunas branco variaram entre 457 e $165 \mathrm{mV}$ e è apresentado na FIG. 5.7. Analisando os resultados de Eh deste experimento e 0 gráfico proposto por Brookins (1998), (FIG. 5.8) observa-se que possivelmente 0 efluente da coluna de solo encontra-se entre um meio oxidante e de transição entre oxidante-redutor após a lixiviação da coluna branco.

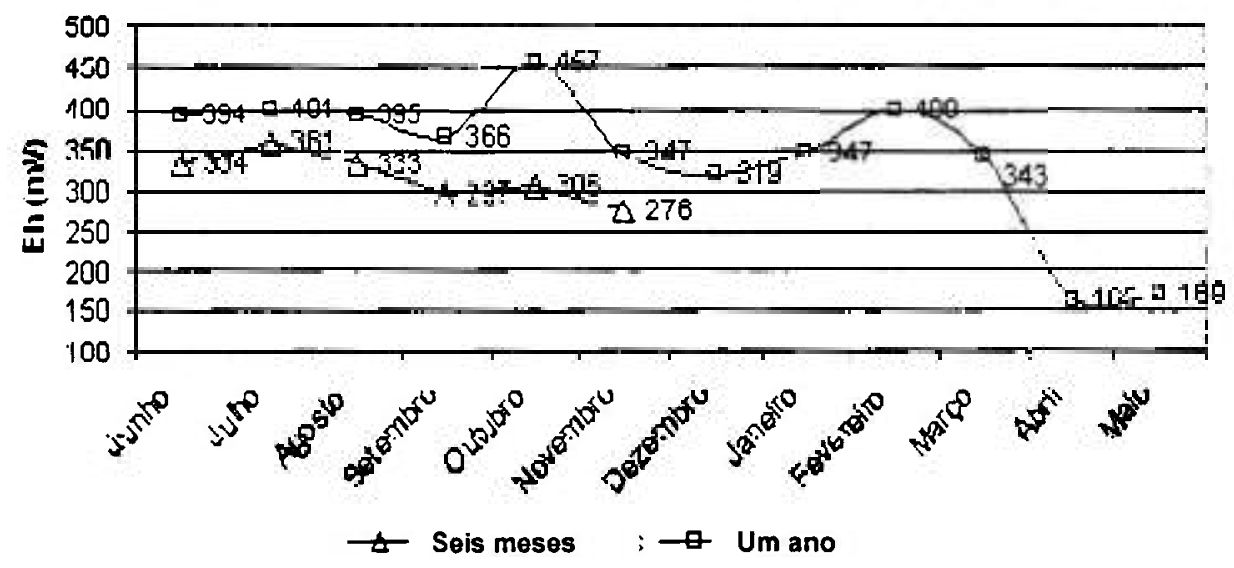

FIGURA 5.7 - Variação do Eh nos efluentes das colunas branco lixiviadas por seis meses e um ano.

A condutividade elétrica nos efluentes mostra a quantidade de ions que estão sendo lixiviados da coluna. A condutividade nos efluentes variou de 9 a 586 $\mu \mathrm{Scm}^{-1}$ (FIG. 5.9). A tendência da condutividade durante a lixiviação da coluna é 
diminuir com o tempo por causa da redução de ions que podem ser lixiviados da coluna de solo.

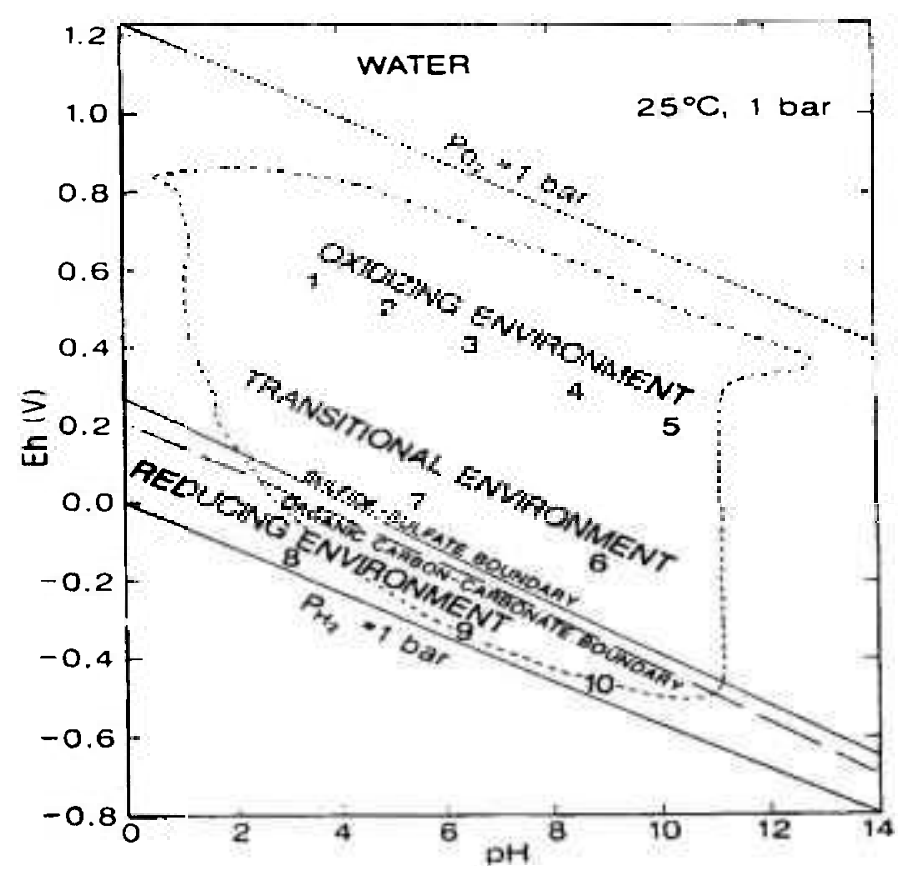

FIGURA 5.8 - Ambiente oxi-redutor conforme os valores de $\mathrm{pH}$ e Eh segundo Brookins (1988).

A condutividade elétrica nos efluentes mostra a quantidade de ions que estão sendo lixiviados da coluna. A condutividade nos efluentes variou de 9 a 586 $\mu \mathrm{Scm}^{-1}$ (FIG. 5.9). A tendência da condutividade durante a lixiviação da coluna é diminuir com o tempo por causa da redução de íons que podem ser lixiviados da coluna de solo.

\subsubsection{Colunas Contaminadas}

O volume dos efluentes recuperado das colunas ao final da percolação, por vezes, é menor que o adicionado (FIG. 4.7). O volume recuperado das colunas contaminadas de solo é apresentado na FIG. 5.10. 


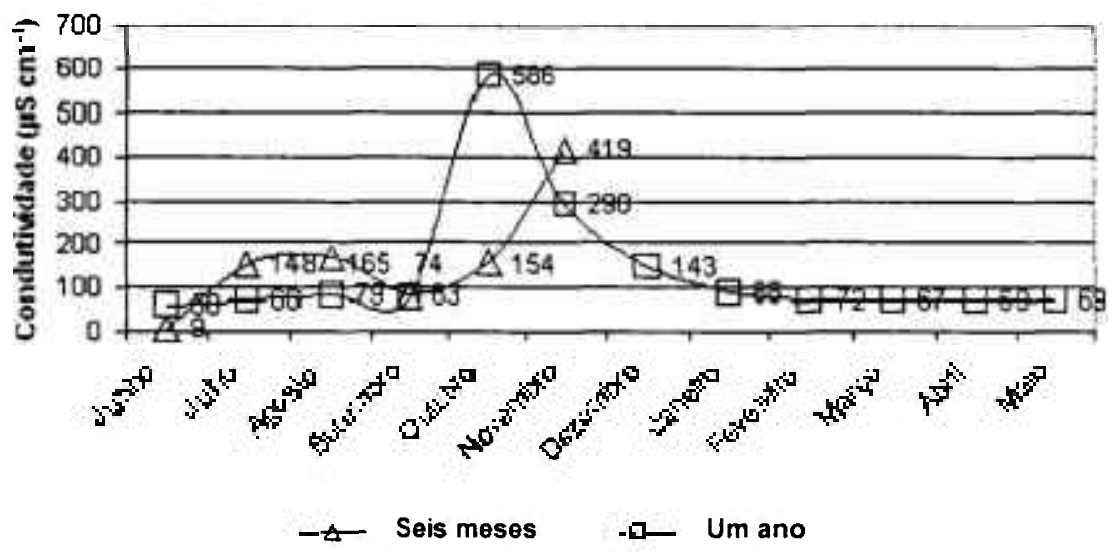

FIGURA 5.9 - Variação da condutividade elétrica nos efluentes das colunas branco lixiviadas por seis meses e um ano.

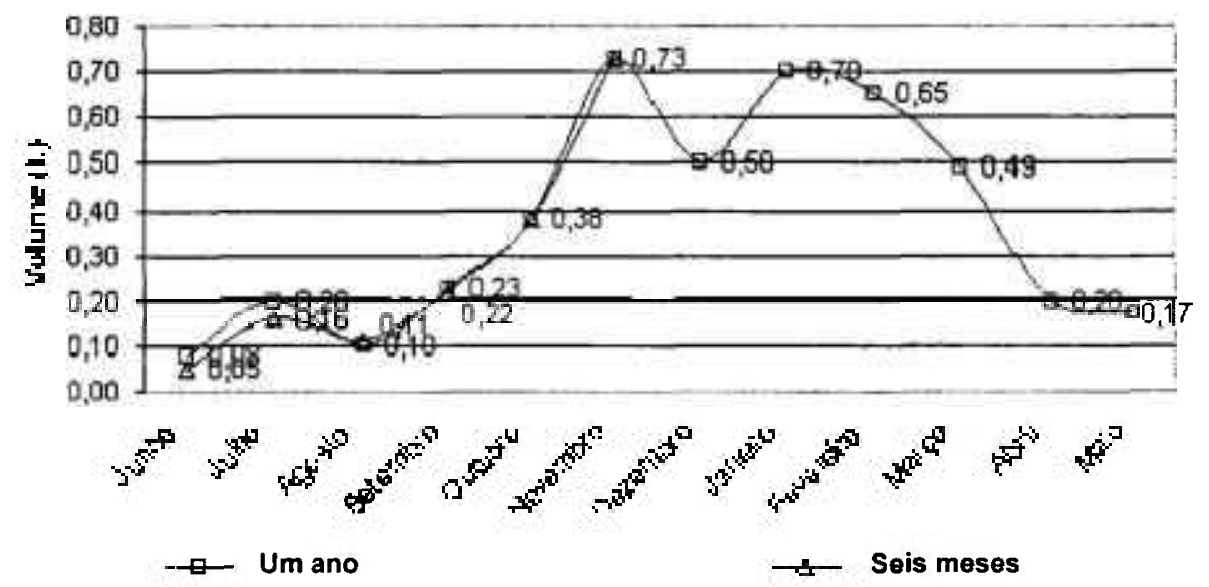

FIGURA 5.10 - Volume dos efluentes das colunas contaminadas lixiviadas durante seis meses e um ano.

$\mathrm{O}$ pH no efluente das colunas contaminadas (FIGURA 5.11) variaram de 3,86 a 4,74 . $\mathrm{O} \mathrm{pH}$ dos efluentes das quatro colunas teve um comportamento semelhante 
ao longo do período. As colunas de um ano, tanto a branco quanto a contaminada, com o passar do tempo voltaram a apresentar valores de $\mathrm{pH}$ próximos aos iniciais.

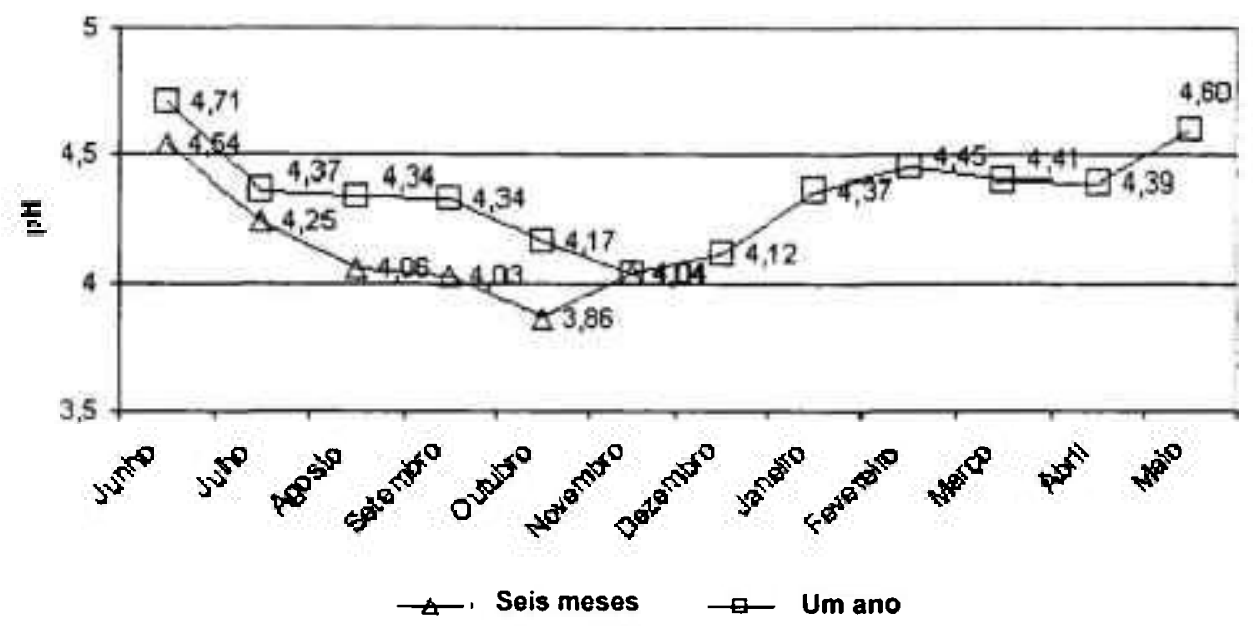

FIGURA 5.11 - Variação do pH nos efluentes das colunas contaminadas lixiviadas por seis meses e de um ano.

O Eh em ambas as colunas contaminadas variaram de 445 a $149 \mathrm{mV}$ (FIG. 5.12). De acordo com a figura proposta por Brookins (1988) (FIG. 5.8) o Eh observado no efluente das colunas contaminadas sugere um meio oxidante e de transição entre oxidante-redutor.

Nos efluentes das colunas contaminadas observou-se uma maior condutividade elétrica em relação às colunas branco, com picos de condutividade acima de $3175 \mu \mathrm{Scm}^{-1}$, e faixa de valores entre 89 e $4790 \mu \mathrm{Scm}^{-1}$ (FIG. 5.13). Este comportamento era esperado, já que a lixiviação das pilhas sobre as colunas do solo introduz ions ao solo e consequentemente pode aumentar os íons no efluente. Os gráficos obtidos para a condutividade elétrica dos efluentes das colunas contaminadas e branco apresentaram um comportamento semelhante às curvas típicas de eluição de colunas trocadoras catiônicas. 


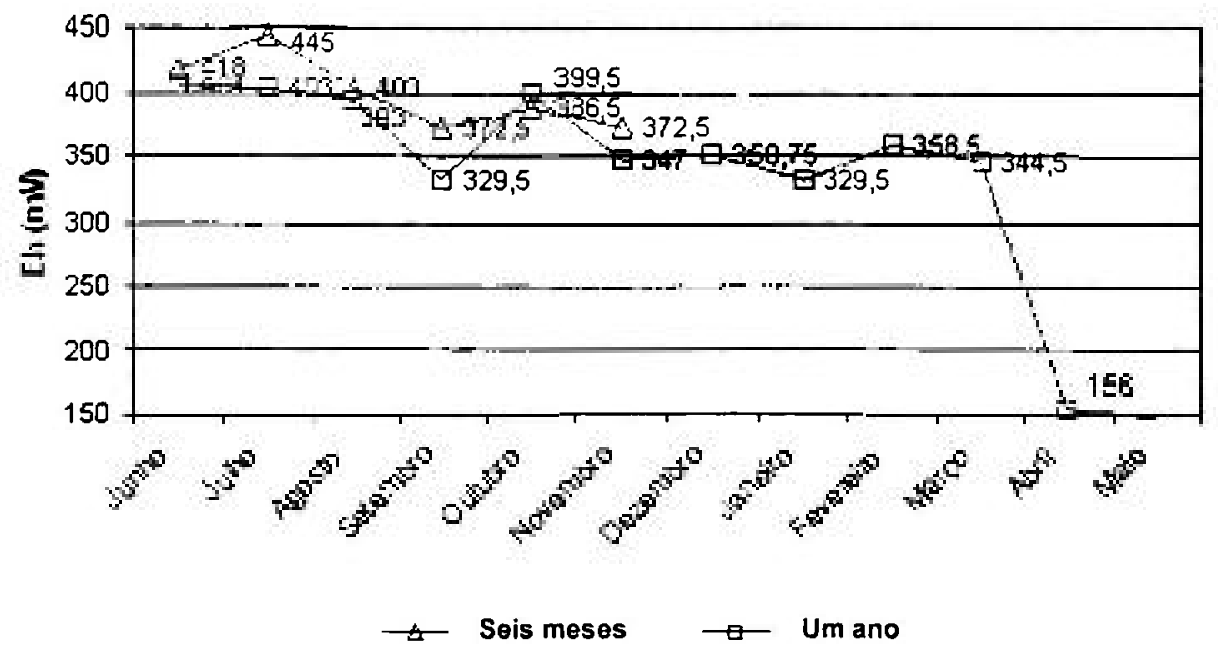

FIGURA 5.12 - Variação do Eh nos efluentes das colunas contaminadas lixiviadas por seis meses e um ano.

O aumento da condutividade elétrica nos efluentes das quatro colunas está associado ao decréscimo do pH, resultado de um aumento da concentração dos íons liberados da coluna de solo.

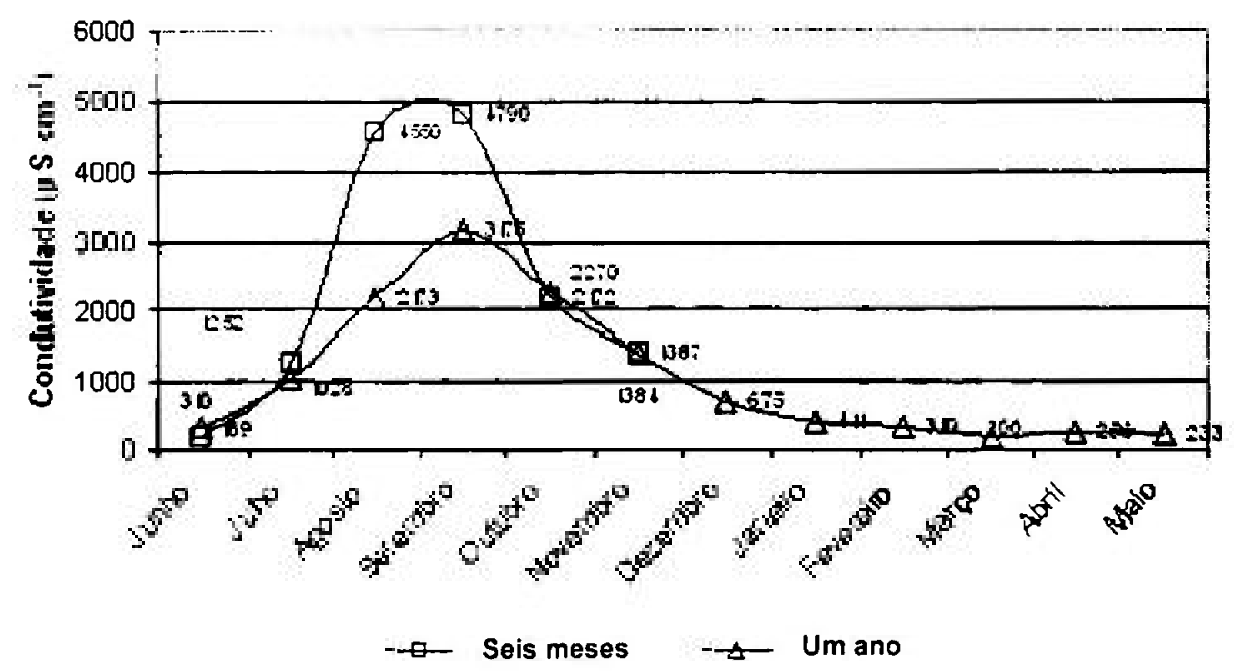

FIGURA 5.13 - Variação da condutividade elétrica nos efluentes das colunas contaminadas lixiviadas por seis meses e um ano. 


\subsubsection{Avaliação dos Metais nos efluentes}

A concentração dos metais $(\mathrm{Zn}, \mathrm{Mn}, \mathrm{Pb}, \mathrm{Ni}, \mathrm{Cr}, \mathrm{Cd}, \mathrm{Cu})$ nos efluentes foram determinados segundo a metodologia descrita no item 4.7.

Os resultados das concentrações dos metais, em $\mathrm{mg} \mathrm{L}^{-1}$, nos efluentes das quatro colunas lixiviadas encontram-se na TAB. A1. As concentrações mensais dos metais em $\mathrm{mg} \mathrm{L}^{-1}$ foram multiplicadas pelos seus respectivos volumes $(L)$, coletados de cada uma das colunas (FIG 5.5 e 5.10). Este cálculo permitiu obter a massa (mg) do metal mensal por efluente da coluna.

\subsubsection{Coluna Branco}

Nas FIG. 5.14 a 5.20 apresentam-se as massas dos metais nos efluentes coletados mensalmente.

\section{Chimbn}

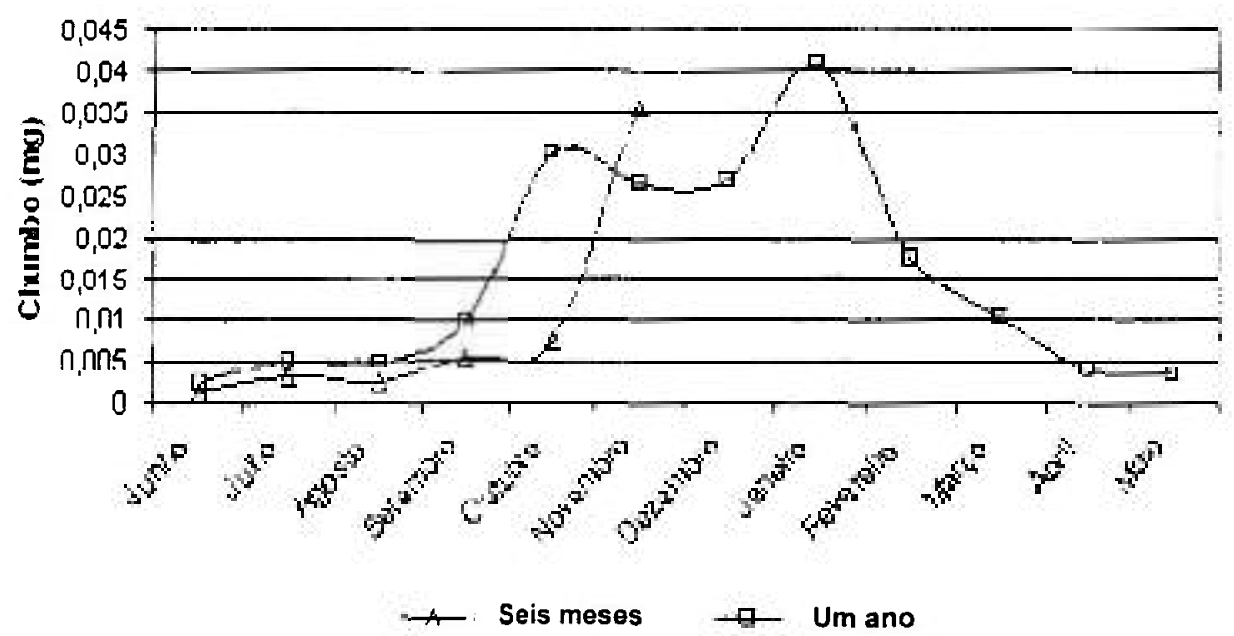

FIGURA 5.14 - Massa (mg) de chumbo presente nos efluentes mensais das colunas branco seis meses e 1 ano. 


\section{Cadmio}

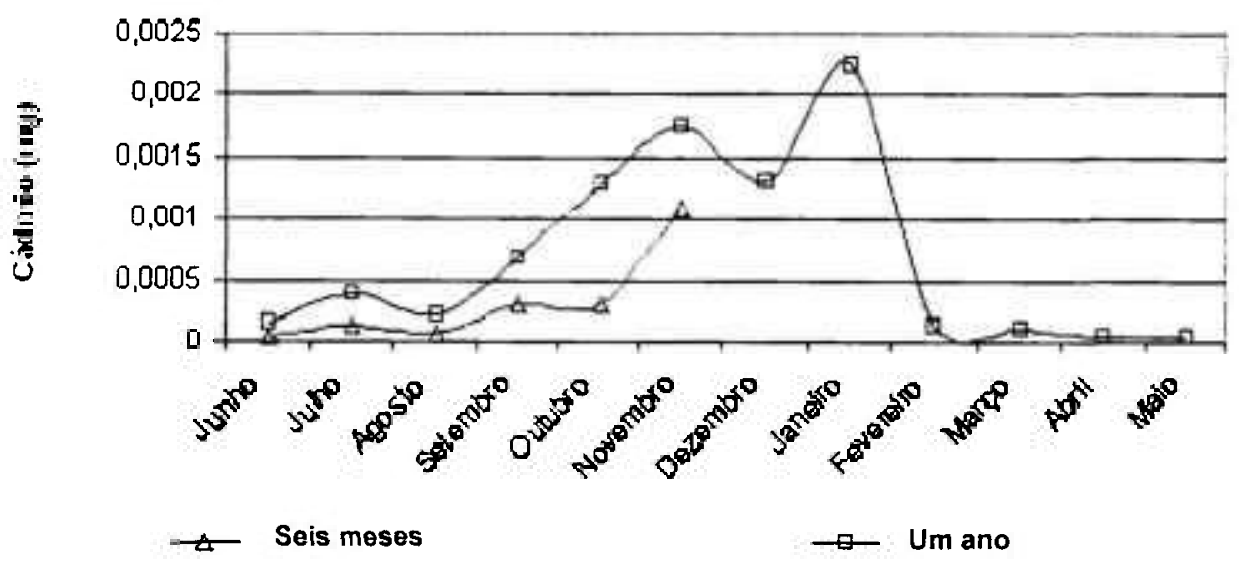

FIGURA 5.15 - Massa (mg) de cádmio presente nos efluentes das colunas branco seis meses e 1 ano.

\section{Zinco}

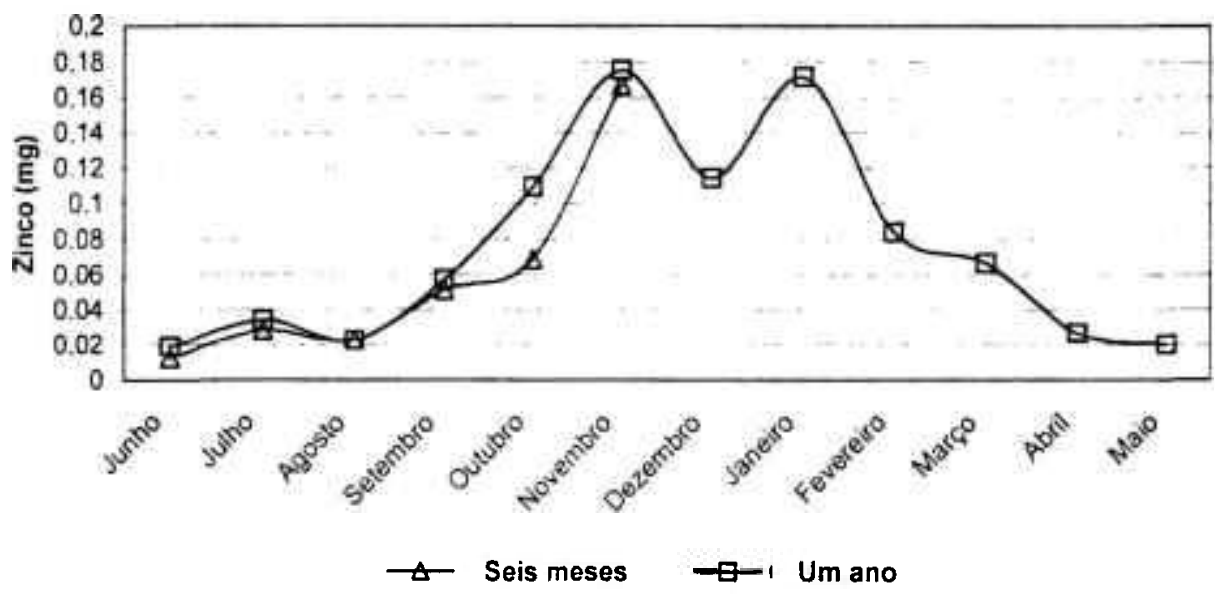

FIGURA 5.16 - Massa (mg) de zinco presente nos efluentes das colunas branco seis meses e 1 ano. 
Cobre

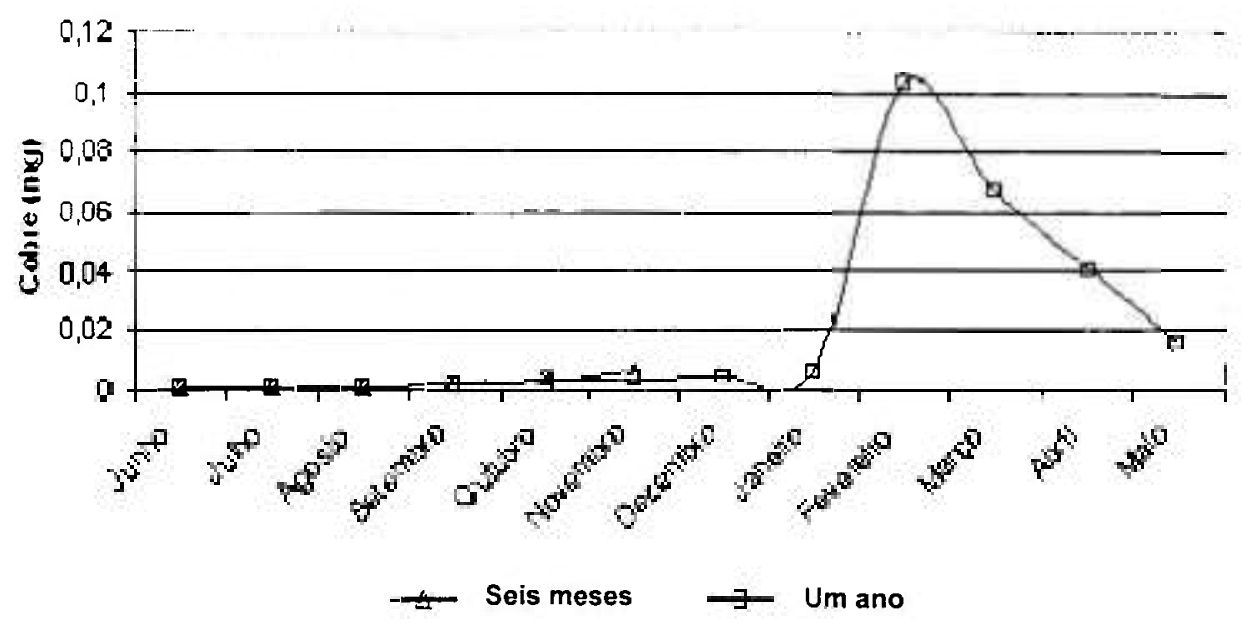

FIGURA 5.17 - Massa (mg) de cobre presente nos efluentes das colunas branco seis meses e 1 ano.

\section{Niquel}

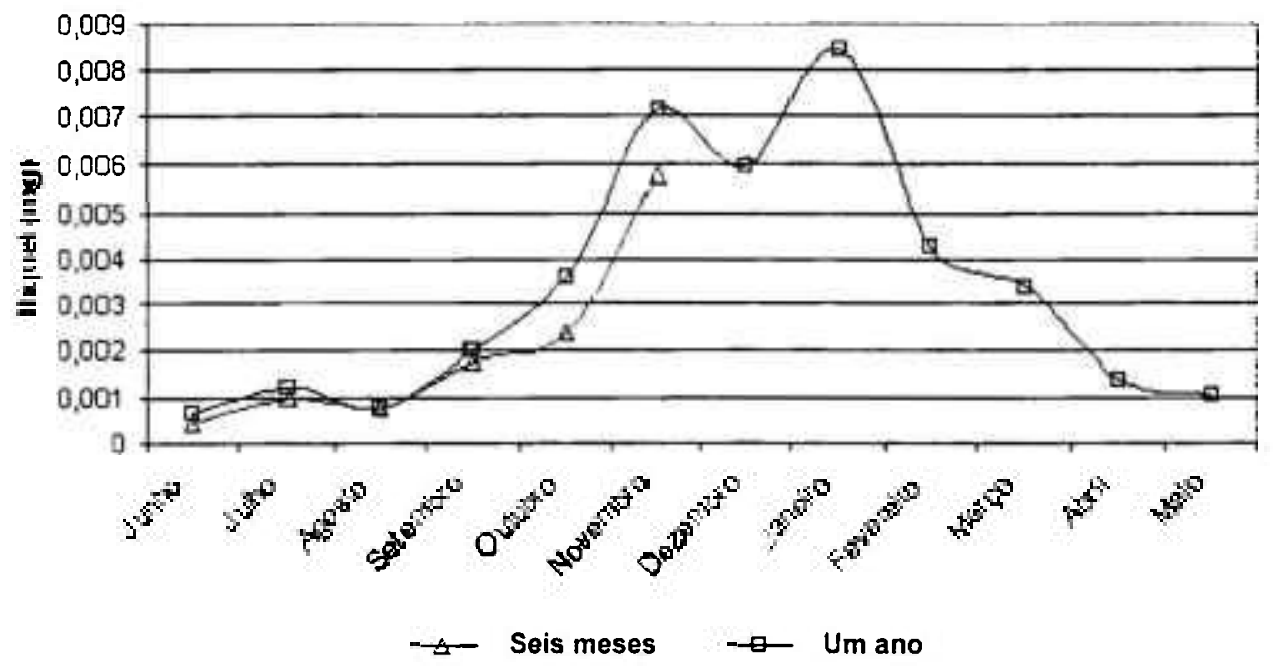

FIGURA 5.18 - Massa (mg) de niquel presente nos efluentes das colunas branco seis meses e 1 ano. 


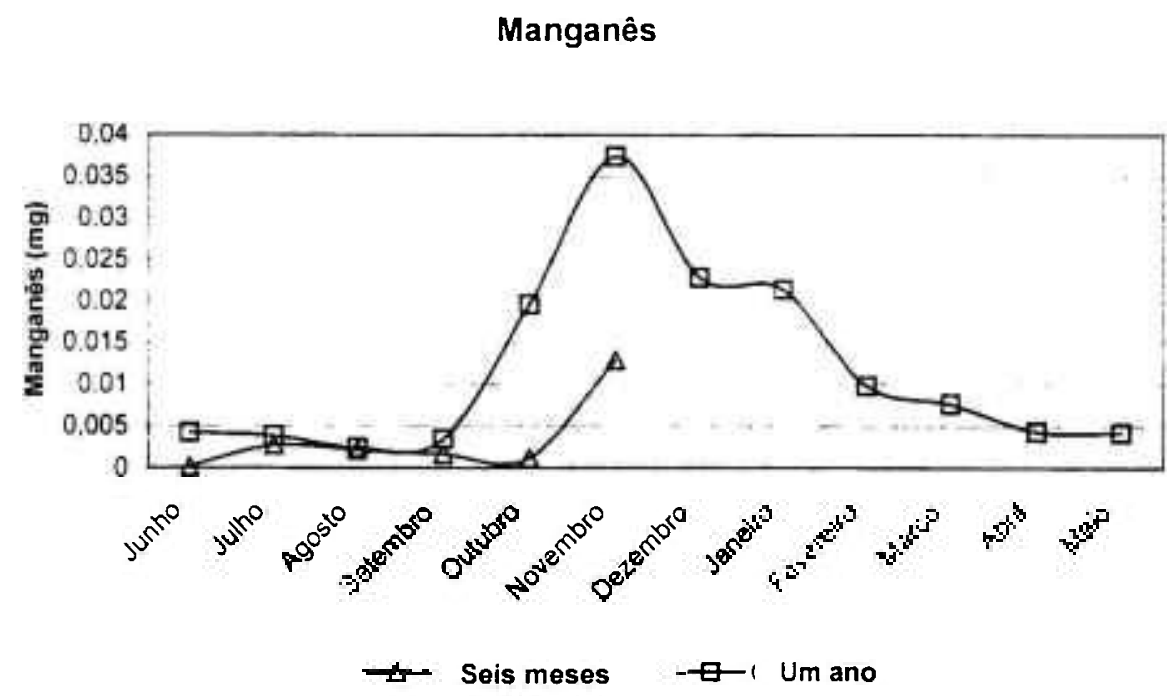

FIGURA 5.19 - Massa (mg) de manganês presente nos efluentes das colunas branco seis meses e 1 ano.

\section{Cromo}

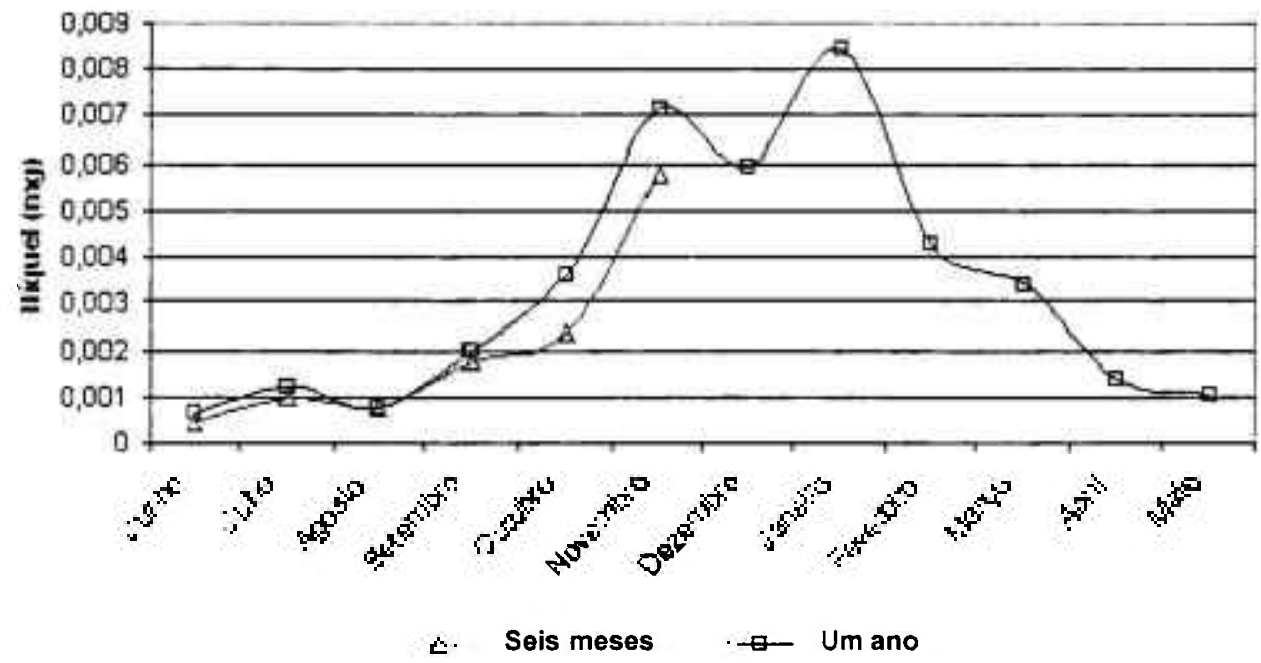

FIGURA 5.20 - Massa (mg) de cromo presente nos efluentes das colunas branco seis meses e 1 ano. 
Zinco foi o metal mais lixiviado da coluna branco apresentando massas mensais variando de 0,017 a $0,18 \mathrm{mg}$, em segundo lugar estão o manganês $(0,001$ a $0,037 \mathrm{mg})$ e o chumbo $(0,01 \mathrm{a} 0,04 \mathrm{mg})$. Os demais metais apresentaram massas inferiores a 0,01 $\mathrm{mg}$ nos efluentes.

As curvas de lixiviação dos metais, com exceção do cobre, apresentaram o mesmo perfil da curva do volume (FIG. 4.7) da solução "água de chuva" adicionada às colunas de solo.

\subsubsection{Coluna Contaminada}

Nas FIG. 5.21 a 5.27 apresentam-se as massas dos metais nos efluentes das colunas contaminadas coletados mensalmente.

A massa dos metais ( $\mathrm{Pb}, \mathrm{Mn}, \mathrm{Zn}, \mathrm{Ni}, \mathrm{Cr}, \mathrm{Cd}, \mathrm{Cu}$ ) presente nos efluentes das colunas contaminadas foi maior que a encontrada nos efluentes das colunas branco (FIG. 5.14 a 5.20). Isso já era esperado devido a maior condutividade elétrica apresentada pelas efluentes das colunas contaminadas em relação ao branco (FIG. 5.9 e 5.13$)$.

\section{Chumbo}

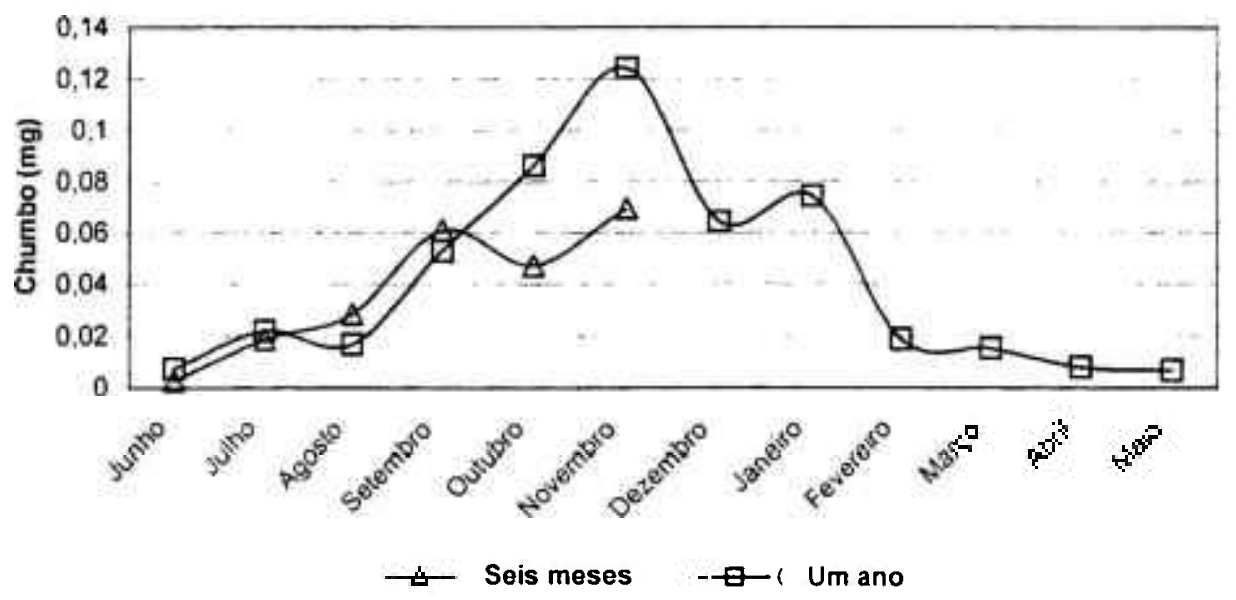

FIGURA 5.21 - Massa (mg) de chumbo presente nos efluentes mensais das colunas contaminadas 6 meses e 1 ano. 


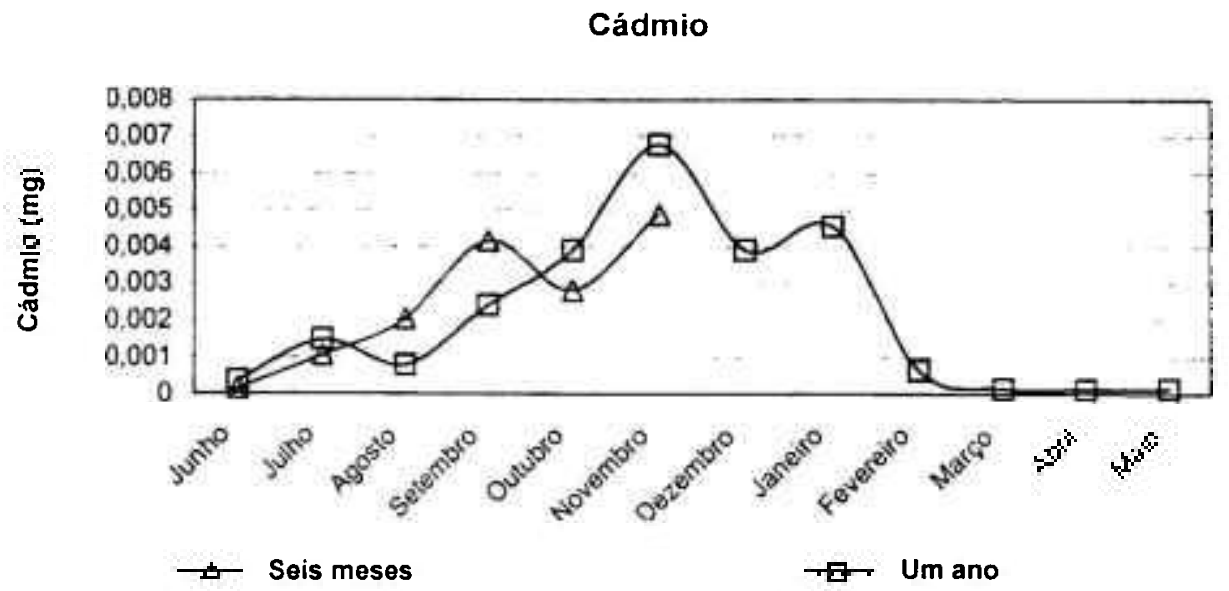

FIGURA 5.22 - Massa (mg) de cádmio presente nos efluentes mensais das colunas contaminadas 6 meses e 1 ano.

\section{Zinco}

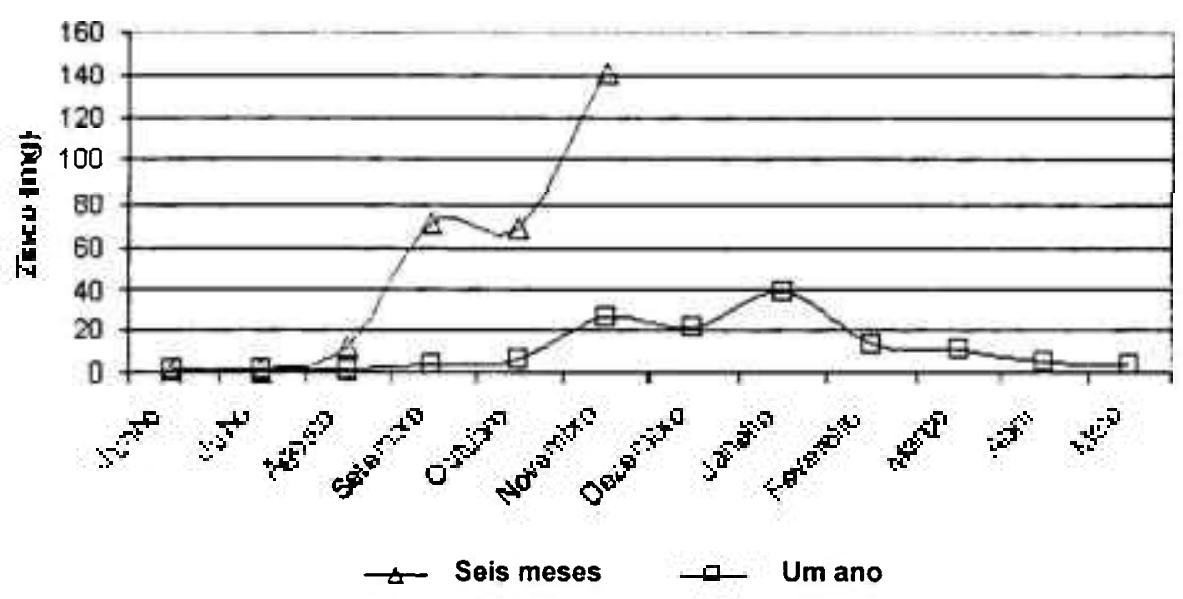

FIGURA 5.23 - Massa (mg) de zinco presente nos efluentes mensais das colunas contaminadas 6 meses e 1 ano. 


\section{Colore}

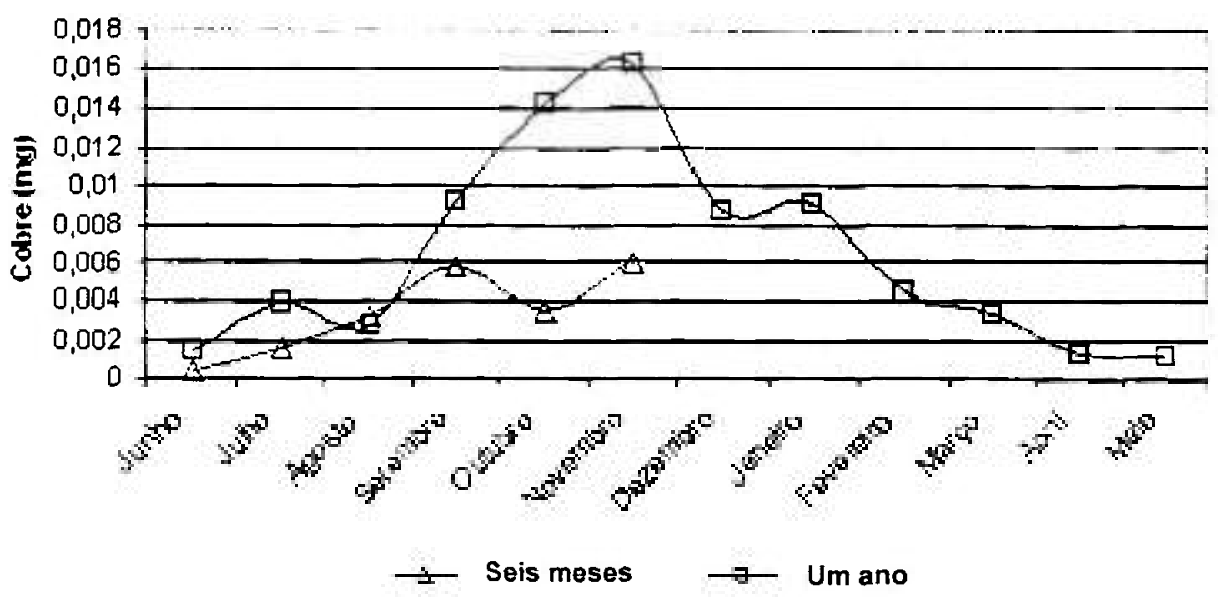

FIGURA 5.24 - Massa $(\mathrm{mg})$ de cobre presente nos efluentes mensais das colunas contaminadas 6 meses e 1 ano.

\section{Nicpuel}

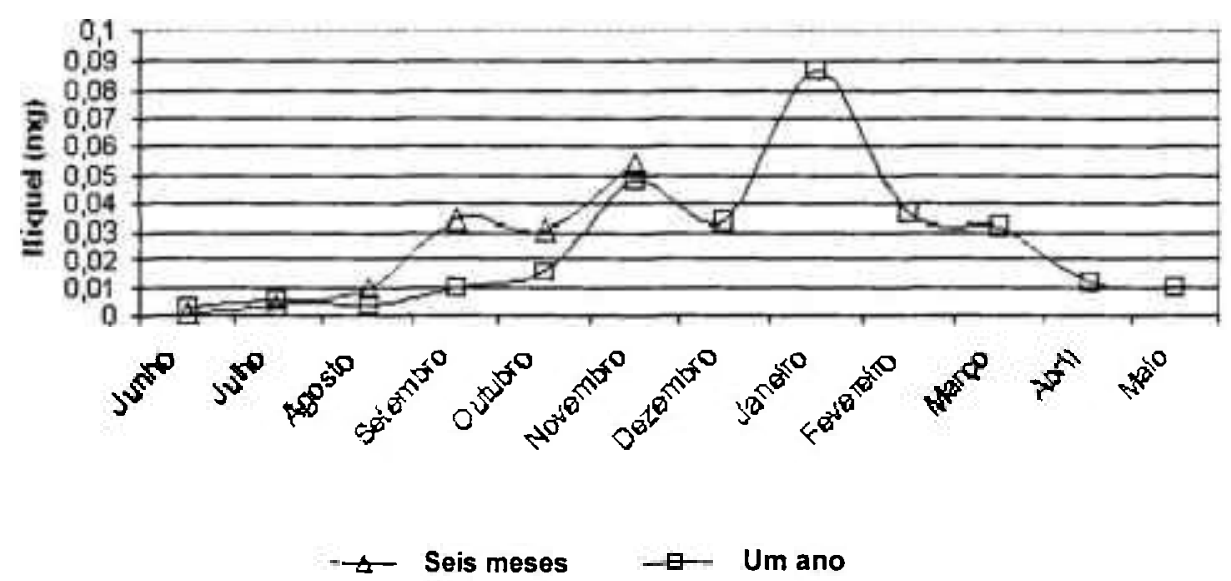

FIGURA 5.25 - Massa (mg) de níquel presente nos efluentes mensais das colunas contaminadas 6 meses e 1 ano. 


\section{Manganes}

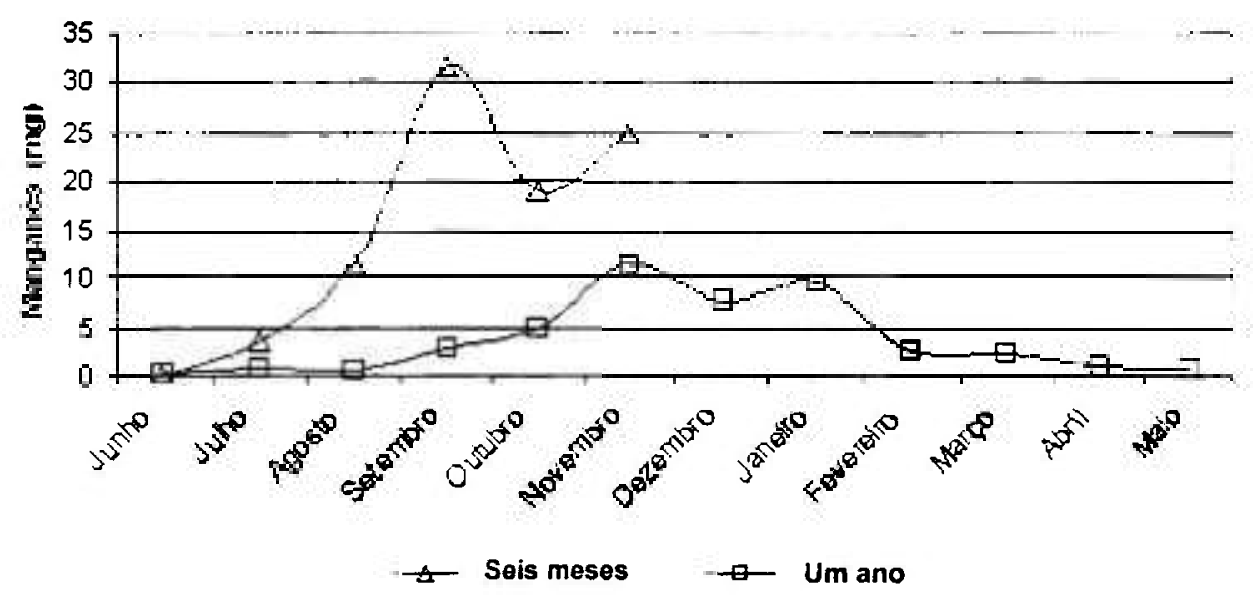

FIGURA 5.26 - Massa $(\mathrm{mg})$ de manganês presente nos efluentes mensais das colunas contaminadas 6 meses e 1 ano.

\section{Cromo}

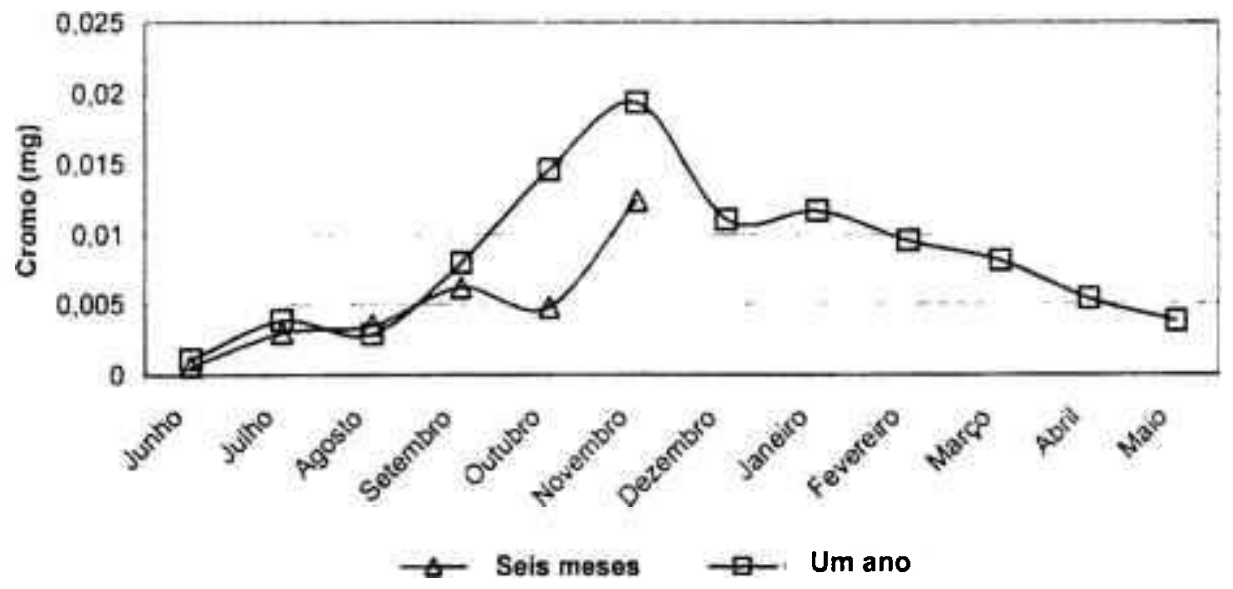

FIGURA 5.27 - Massa (mg) de cromo presente nos efluentes mensais das colunas contaminadas 6 meses e 1 ano. 


\subsubsection{Branco $\times$ Contaminada}

Para avaliar a massa de metal lixiviado da coluna de solo multiplicou-se a concentração do metal no efluente $\left(m g L^{-1}\right), T A B$. $A 1$, pelo volume $(L)$ do efluente mensal, FIG. 5.5 e 5.10. A massa total acumulada $(\mathrm{mg})$ dos metais das colunas foi obtida pela somatória das massas mensais por efluente das quatro colunas e são apresentadas na TAB. 5.2 .

TABELA 5.2 - Massa total acumulada $(\mathrm{mg})$ dos metais encontrados nos efluentes das quatro colunas (branco, contaminada, seis meses e um ano).

\begin{tabular}{ccccccccc}
\hline & Massa Total $(\mathrm{mg})$ & $\mathrm{Zn}$ & $\mathrm{Mn}$ & $\mathrm{Pb}$ & $\mathrm{Ni}$ & $\mathrm{Cd}$ & $\mathrm{Cu}$ & $\mathrm{Cr}$ \\
\hline \multirow{2}{*}{ Colunas branco } & Seis meses & 0,35 & 0,021 & 0,055 & 0,012 & 0,002 & 0,013 & 0.016 \\
& Um ano & 0,90 & 0,142 & 0,182 & 0,040 & 0,008 & 0,249 & 0,056 \\
\multirow{2}{*}{ Colunas Contaminadas } & Seis meses & 293 & 90 & 0,227 & 0,13 & 0,015 & 0,021 & 0,031 \\
& Um ano & 132 & 44 & 0,497 & 0,29 & 0,025 & 0,076 & 0.099 \\
\hline
\end{tabular}

Uma análise da massa acumulada de metal nos efluentes das colunas contaminada mostrou que $\mathrm{Zn}$ e $\mathrm{Mn}$ foram os metais que apresentaram as maiores massas no lixiviado, seguidos de $\mathrm{Pb}$ e $\mathrm{Ni}$. Os metais $\mathrm{Cd}, \mathrm{Cu}$ e $\mathrm{Cr}$ apresentaram-se em baixas concentrações nos efluentes. A alta massa de $\mathrm{Zn}$ e Mn lixiviada já era esperada, pois estes dois metais são majoritários na pilha e tendem em solos ácidos e lixiviação ácida ("água de chuva") ser facilmente transportados para o efluente.

A massa da média dos metais nos efluentes das colunas branco e contaminada e a concentração dos metais obtida na lixiviação somente das pilhas (item 5.2) mostraram a seguinte seqüência decrescente:

- Colunas Branco: $\quad \mathrm{Zn}>\mathrm{Pb}>\mathrm{Mn}>\mathrm{Cu}>\mathrm{Ni}=\mathrm{Cr}>\mathrm{Cd}$

- Colunas contaminadas: $\mathrm{Zn}>\mathrm{Mn}>\mathrm{Pb}>\mathrm{Ni}>\mathrm{Cr}>\mathrm{Cu}>\mathrm{Cd}$.

- Lixiviação da pilha: $\quad \mathrm{Zn}>\mathrm{Mn}>\mathrm{Pb}>\mathrm{Ni}>\mathrm{Cr}>\mathrm{Cd}>\mathrm{Cu}$.

A seqüência das colunas contaminada foi semelhante a da lixiviação das pilhas, mostrando a influência das pilhas nas caracteristicas do efluente dessas colunas. 
A massa de zinco e de manganês presentes na coluna contaminada e nos efluentes de seis meses foi maior do que a massa obtida para a coluna contaminada de um ano. Observou-se que a coluna contaminada seis meses apresentava um escoamento mais lento o que causou uma acumulação da solução "água de chuva" no topo da coluna por mais tempo. A pasta das pilhas em contato prolongado com a solução lixiviadora deve ter facilitado à liberação de concentrações maiores destes metais.

O perfil das curvas dos efluentes das colunas contaminadas, assim como a das colunas branco, foi semelhante ao perfil da curva do volume adicionado de solução "água de chuva" (FIG. 4.7). A aplicação da matriz de correlação de Pearson ( $p<0,5000$ ), aos dados dos efluentes mostrou que a massa de metais e o volume de solução adicionado apresentaram correlação positiva $(r>0,75)$, indicando que o aumento desses metais nos efluentes das quatro colunas está associado ao aumento de volume da solução "água de chuva" percolado pela coluna.

A correlação também mostrou que a concentração de todos os metais no efluente possuem correlação positiva entre si $(r>0,75)$, indicando a existência de comportamento semelhante entre os metais. Observou-se também uma correlação negativa entre os resultados de Eh e pH. De acordo com Alloway (1995) e McBride (1994) os valores de Eh estão negativamente correlacionados com pH e em ambiente ácido promovem maior lixiviação dos metais.

\subsection{Colunas de Solo}

As cinco colunas (uma original, duas branco, duas contaminadas) de solo indeformadas utilizadas neste trabalho foram seccionadas em 3 frações: superior (0 $5 \mathrm{~cm}$ ), média $(5-15 \mathrm{~cm})$ e inferior $(15-25 \mathrm{~cm})$. O resíduo que sobrou das três pilhas no topo de cada uma das colunas contaminadas foi cuidadosamente retirado, para que o solo da camada superior tivesse somente a contaminação de metais infiltrada no solo.

Nas amostras de solo de cada fração secas e homogenizadas foram determinadas a concentração parcial e biodisponivel (método descrito no item 4.6) 
dos metais $(\mathrm{Zn}, \mathrm{Mn}, \mathrm{Pb}, \mathrm{Ni}, \mathrm{Cr}, \mathrm{Cd}$ e $\mathrm{Cu}$ ) pela técnica ICP-OES. Os resultados encontram-se nas Tab. A2 e A3.

Para avaliar a disponibilidade dos metais em cada coluna de solo determinou-se a porcentagem de disponibilidade. Esta porcentagem foi obtida pela razão da concentração biodisponivel e a concentração parcial conforme equação 5.5:

$$
>\% \text { disponivel }=\frac{\text { Concentracão biodisponivel }}{\text { Concentração parcial }} \times 100
$$

Para melhor visualizar e avaliar a concentração e mobilidade dos metais nas colunas de solo traçou-se os gráficos de barras horizontais das frações (superior, media e inferior) das várias colunas estudadas.

\subsubsection{Coluna de solo original}

A coluna original corresponde à coluna de solo que não foi lixiviada com "água de chuva", portanto as concentrações dos metais determinadas referem-se à situação do solo no dia da coleta. Estes valores são importantes para comparação com as colunas branco e contaminada. Com os resultados da concentração parcial dos metais $\mathrm{Zn}, \mathrm{Mn}, \mathrm{Pb}, \mathrm{Ni}, \mathrm{Cr}, \mathrm{Cd}$ e $\mathrm{Cu}$ nas três frações de solo da coluna original construiu-se a FIG. 5.28 .

Os metais $\mathrm{Pb}$ e $\mathrm{Mn}$ encontraram-se acumulados nas fraçōes superior e inferior da coluna de solo. O chumbo foi o metal que apresentou a maior concentração na coluna de solo original, os valores variaram de 28 a $52 \mathrm{mg} \mathrm{kg}^{-1}$. De acordo com a literatura a concentração mundial de $\mathrm{Pb}$ em solo pode estar entre $10 \mathrm{a}$ $84 \mathrm{mg} \mathrm{kg}^{-1}$ (McBride, 1994) e Alloway (1995) sugere que concentrações de Pb entre 30 a $100 \mathrm{mg} \mathrm{kg}^{-1}$ podem representar solos pouco contaminados.

O manganês tem distribuição aleatória no solo e se encontra comumente nos solos na forma de óxidos, cuja solubilidade é muito variável de um ambiente para outro. Em clima tropical. a acumulação ocorre preferencialmente nas camadas superiores do solo, Dauga (2000). De acordo com McBride (1994) a concentração mundial de $\mathrm{Mn}$ no solo pode variar de 80 a $1300 \mathrm{mg} \mathrm{kg}^{-1}$. 


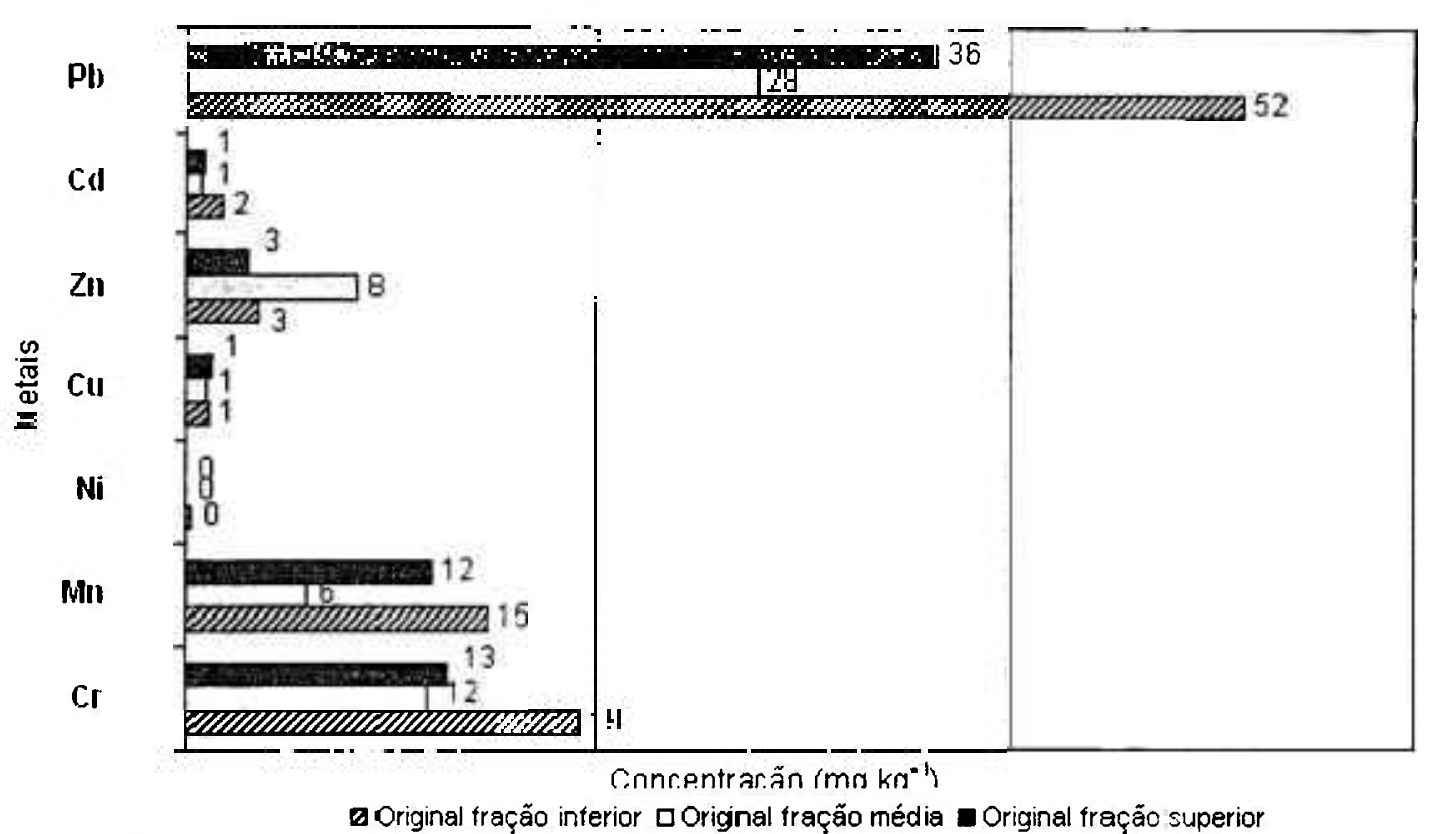

FIGURA 5.28 - Concentração parcial dos metais $\mathrm{Pb}, \mathrm{Cd}, \mathrm{Zn}, \mathrm{Cu}, \mathrm{Ni}, \mathrm{Mn}$ e $\mathrm{Cr}$ em $\mathrm{mg} \mathrm{kg}^{-1}$ nas frações superior, média e inferior da coluna de solo original.

* Ni esta abaixo do limite de deteç̧ão na fração média $\left(0,0061 \mathrm{~m} \mathrm{~L} \mathrm{~L}^{-1}\right)$, o valor para a fração superior é $0.15 \mathrm{mg} \mathrm{kg}^{-1}$ e na inferior é $0.19 \mathrm{mg} \mathrm{kg}^{-1}$

O zinco na coluna de solo original está acumulado na fração média e tanto o $\mathrm{Zn}$ como o $\mathrm{Cu}, \mathrm{Cd}$ e o $\mathrm{Ni}$ apresentaram-se em baixas concentraçōes no solo. No caso dos metais $\mathrm{Cu}, \mathrm{Cd}$ e $\mathrm{Ni}$ a sua distribuição na coluna de solo é praticamente homogênea.

A seqüência de concentração dos metais na coluna de solo original foi estabelecida pela somatória das 3 frações e mostrou que $\mathrm{Pb}$ se apresentou em maior concentração no solo em estudo e Ni em menor concentração:

$$
>\mathrm{Pb}>\mathrm{Cr} \geq \mathrm{Mn}>\mathrm{Zn}>\mathrm{Cd} \geq \mathrm{Cu} \geq \mathrm{Ni}
$$

As porcentagens de disponibilidade dos metais $\mathrm{Pb}, \mathrm{Cd}, \mathrm{Zn}, \mathrm{Cu}, \mathrm{Ni}, \mathrm{Mn}$ e $\mathrm{Cr}$ no solo da coluna original por fração foram calculadas pela equaçāo 5.5 , e estão apresentadas na FIG. 5.29. 


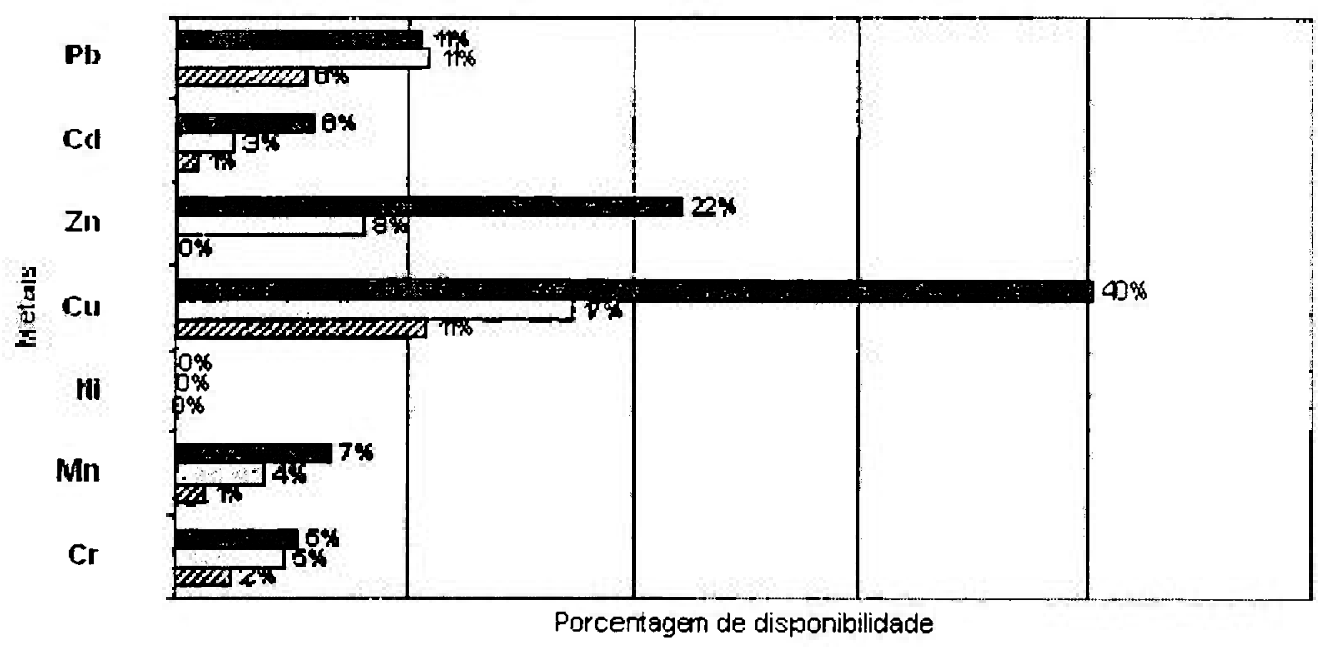

๒ Original traçẫo inferior $\square$ Orignal tração média a Original fração superior

* Os valores de $\mathrm{Ni}$ em todas as fraçōes e de $\mathrm{Zn}$ na fração inferior estão abaixo de 0,001\% FIGURA 5.29 - Porcentagem de disponibilidade dos metais $\mathrm{Pb}, \mathrm{Cd}, \mathrm{Zn}$. $\mathrm{Cu}, \mathrm{Ni}, \mathrm{Mne}$ $\mathrm{Cr}$ das frações superior, média e inferior da coluna de solo original.

Todos os metais encontraram-se mais disponiveis na fração superior do solo. Os metais que apresentaram maior disponibilidade na coluna original foram o cobre e o zinco. De acordo com Kabatas-Pendias \& Pendias (1992), estima-se que $80 \%$ das formas solúveis de cobre sejam quelatos orgânicos, dada a sua grande afinidade aos constituintes orgânicos do solo, a complexação com a matéria orgânica pode influenciar na disponibilidade e migração do cobre no solo.

A seqüência de disponibilidade dos metais na coluna de solo original descrita abaixo mostrou que $\mathrm{Cu}$ se apresentou mais disponibilizado no solo:

$$
\mathrm{Cu}>\mathrm{Zn}>\mathrm{Pb}>\mathrm{Mn} \geq \mathrm{Cd} \geq \mathrm{Cr}>\mathrm{Ni}
$$

Dauga (2000), que estudou os metais $\mathrm{Mn}, \mathrm{Cu}, \mathrm{Pb}$ e $\mathrm{Zn}$ em solos do mesmo local da amostragem das colunas, obteve nos ensaios de disponibilidade, usando EDTA-Na , água e solução levemente acidificada, alta porcentagem de extração para - $\mathrm{Cu}, \mathrm{Zn}$ e $\mathrm{Pb}$, sendo que as porcentagens também diminuiram com a profundidade. 
Sigolo et al (1998) observaram que o níquel era o elemento mais móvel nesse mesmo solo, usando água deionizada.

\subsubsection{Colunas de Solo Branco}

As colunas de solo branco foram lixiviadas com a solução "água de chuva" durante o período correspondente a cada uma delas, de junho a novembro para a coluna de seis meses, e de junho a maio para a coluna de um ano. Ao final de cada periodo as colunas foram seccionadas e analisadas, no entanto, a coluna branco de seis meses ao final do periodo de lixiviação caiu, desorganizando e misturando as frações de solo, o que a inutilizou, portanto apenas a coluna branco de um ano foi analisada.

Com a concentração parcial dos metais $\mathrm{Zn}, \mathrm{Mn}, \mathrm{Pb}, \mathrm{Ni}, \mathrm{Cr}, \mathrm{Cd}$ e $\mathrm{Cu}$ da coluna branco de um ano e de cada fração da coluna construiu-se a FIG. 5.30.

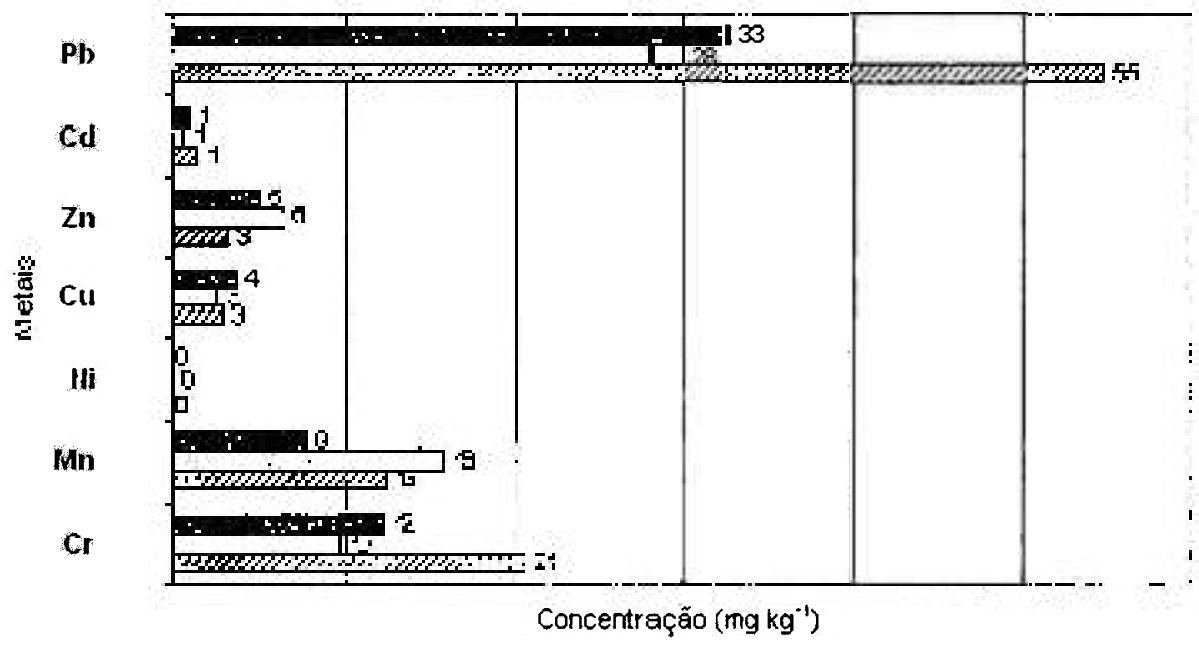

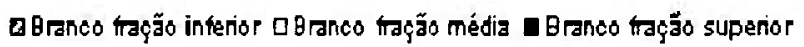

* Ni está abaixo do limite de deteç̧ão na fração média $\left(<0,0061 \mathrm{mg} \mathrm{L}^{-1}\right)$; valor fração superior: $0,8 \mathrm{mg} \mathrm{kg}^{-1}$ e inferior: $14 \mathrm{mg} \mathrm{kg}^{-1}$

FIGURA 5.30 - Concentração parcial dos metais $\mathrm{Pb}, \mathrm{Cd}, \mathrm{Zn}, \mathrm{Cu}, \mathrm{Ni}, \mathrm{Mn}$ e $\mathrm{Cr}$ $\left(\mathrm{mg} \mathrm{kg}^{-1}\right)$ nas frações superior, média e inferior da coluna de solo branco de um ano. 
Observou-se que mesmo após a lixiviação de um ano, a coluna branco apresentou concentração parcial dos metais $\mathrm{Zn}, \mathrm{Mn}, \mathrm{Pb}, \mathrm{Ni}, \mathrm{Cr}, \mathrm{Cd}$ e Cu semelhante a da coluna original. A seqüência decrescente de concentração dos metais desta coluna também foi semelhante à coluna original:

$$
>\mathrm{Pb}>\mathrm{Cr}>\mathrm{Mn}>\mathrm{Zn}>\mathrm{Cu}>\mathrm{Cd} \geq \mathrm{Ni} \text {. }
$$

Portanto, a lixiviação da coluna de solo pela solução "água de chuva", não alterou o comportamento dos metais ao longo das frações de solo.

As porcentagens de disponibilidade dos metais $\mathrm{Pb}, \mathrm{Cd}, \mathrm{Zn}, \mathrm{Cu}, \mathrm{Ni}, \mathrm{Mn}$ e $\mathrm{Cr}$ no solo da coluna branco de um ano por fração foi calculada pela equação 5.5 , e encontram-se na FIG. 5.31.

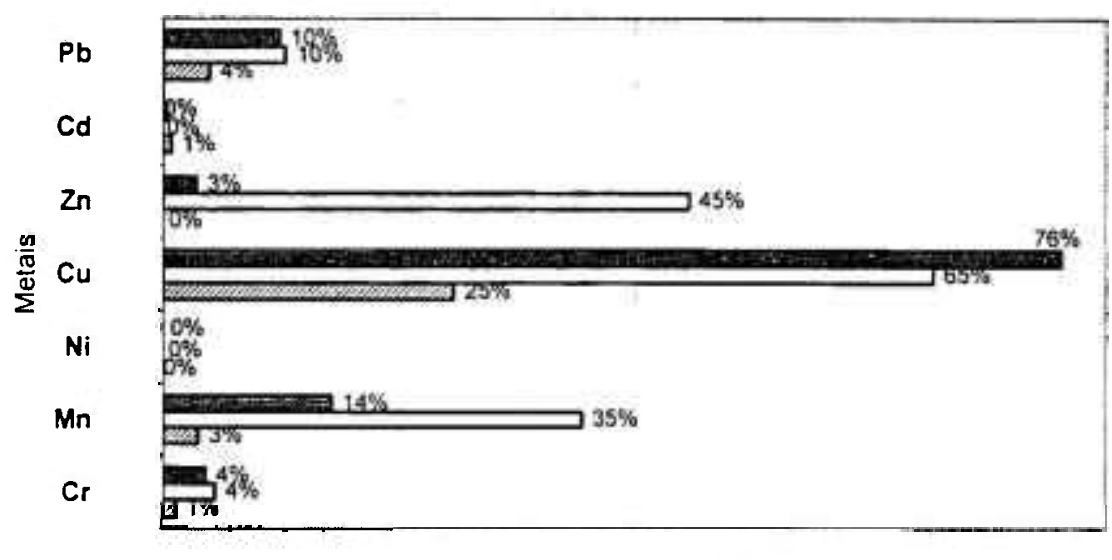

Porcentagem de disponibilidade $\%$

QBranco fração inferior $\square$ Branco fração média Branco fração superior

* Os valores de $\mathrm{Ni}$ em todas as fraçōes e de $\mathrm{Zn}$ na fração inferior estão abaixo de $0,001 \%$ FIGURA 5.31 - Porcentagem de disponibilidade dos metais $\mathrm{Pb}, \mathrm{Cd}, \mathrm{Zn}, \mathrm{Cu}, \mathrm{Ni}, \mathrm{Mn}$ e $\mathrm{Cr}$ das frações superior, média e inferior da coluna de solo branco de um ano.

Comparando a porcentagem de disponibilidade da coluna original e branco observou-se que a lixiviação da coluna de solo pela solução "água de chuva" causou um aumento da disponibilidade dos metais $\mathrm{Cu}, \mathrm{Zn}$ e $\mathrm{Mn}$. 
O zinco e manganês têm a sua disponibilidade maior na camada média, mostrando que $\mathrm{Zn}$ tende a migrar para as camadas inferiores da coluna de solo.

A seqüência de disponibilidade dos metais na coluna de solo branco foi semelhante a original, com exceção do $\mathrm{Mn}$. O Mn aumentou sua disponibilidade na coluna branco que provavelmente se deve a uma possivel dissolução de argilominerais.

$$
>\mathrm{Cu}>\mathrm{Zn}>\mathrm{Mn}>\mathrm{Pb}>\mathrm{Cr}>\mathrm{Cd} \geq \mathrm{Ni}
$$

Hansen \& Postman (1995) observaram que uma solução ácida, com pH entre 4 e 5, promove dissolução de minerais secundários no solo, como a argila, até $5 \mathrm{~m}$ de profundidade.

\subsubsection{Colunas Contaminadas}

As colunas contaminadas por pilhas foram lixiviadas com a solução "água de chuva" durante o período correspondente a cada uma delas, de junho a novembro para a coluna de seis meses, e de junho a maio para a coluna de um ano. Ao final do periodo as colunas foram seccionadas, tratadas e analisadas. Com os resultados da concentração parcial dos metais $\mathrm{Zn}, \mathrm{Mn}, \mathrm{Pb}, \mathrm{Ni}, \mathrm{Cr}, \mathrm{Cd}$ e $\mathrm{Cu}$ nas três frações de solo da coluna contaminada construiu-se as FIG. 5.32 e 5.33 .

As concentrações dos metais $\mathrm{Pb}, \mathrm{Cd}, \mathrm{Zn}, \mathrm{Cu}, \mathrm{Ni}, \mathrm{Mn}$ e $\mathrm{Cr}$, nas colunas contaminadas de seis meses e de um ano, possuem valores superiores aos encontrados nas colunas branco de um ano e original (FIG. 5.28 e 5.30).

Os metais $\mathrm{Pb}, \mathrm{Cd}, \mathrm{Cu}, \mathrm{Ni}$ e $\mathrm{Cr}$ da coluna contaminada assim como nas colunas branco de um ano e original, tendem a se acumular na última camada de solo da coluna. O aumento da concentração destes metais da coluna contaminada em relação à coluna original ou branco foi inferior a um fator de 10 , exceto para $\mathrm{Zn}$, Mn e Ni. 


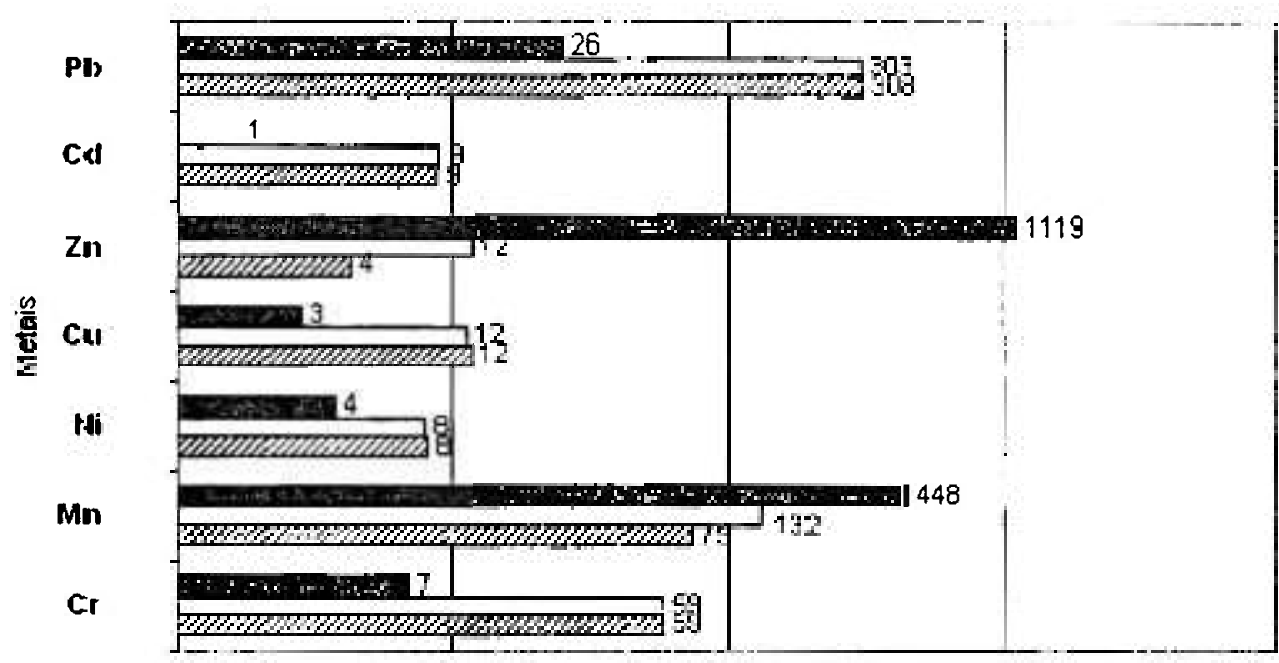

Concentração ( $\left(\mathrm{ng} \mathrm{kg}^{-1}\right)$

Q Cont. frą̧äo inferior QCont. frą̧ão média DCont. frą̧ão superior

FIGURA 5.32 - Concentração parcial dos metais $\mathrm{Pb}, \mathrm{Cd}, \mathrm{Zn}, \mathrm{Cu}, \mathrm{Ni}, \mathrm{Mn}$ e $\mathrm{Cr}$ em mg $\mathrm{kg}^{-1}$ nas frações superior, média e inferior da coluna de solo contaminada de seis meses.

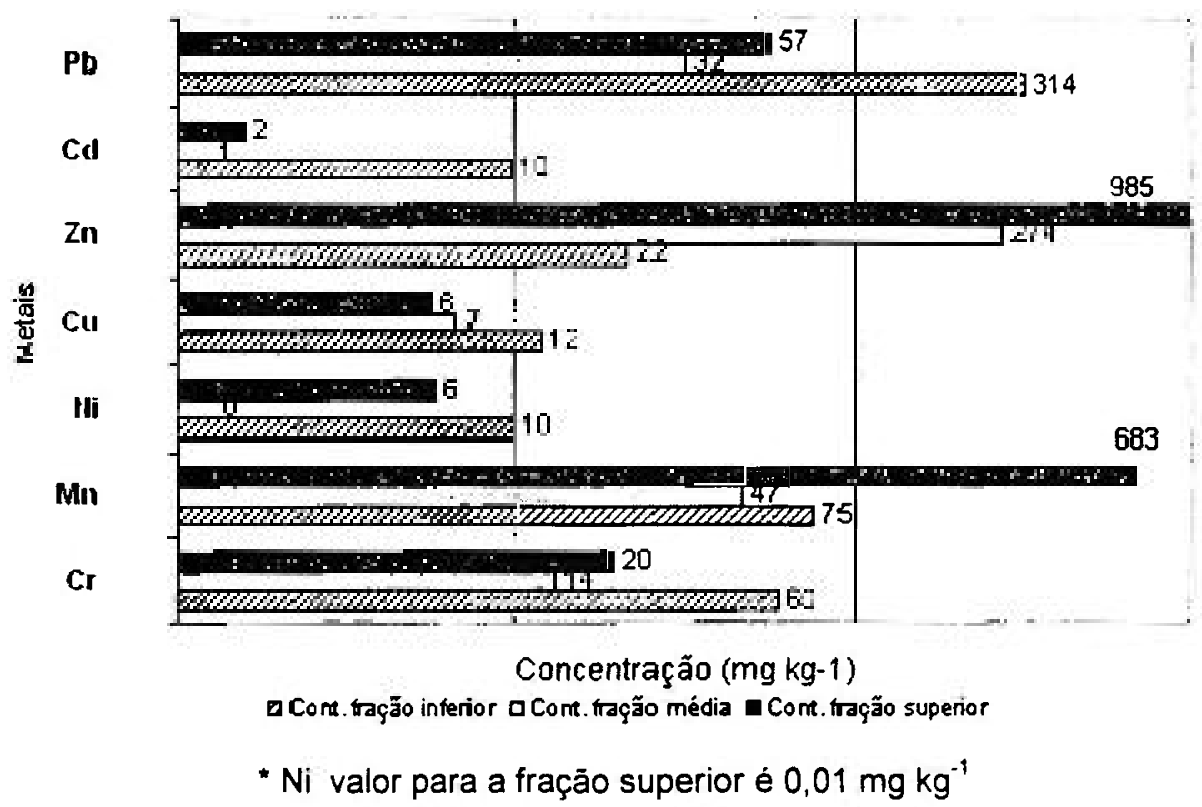

FIGURA 5.33 - Concentração parcial dos metais $\mathrm{Pb}, \mathrm{Cd}, \mathrm{Zn}, \mathrm{Cu}, \mathrm{Ni}, \mathrm{Mn}$ e $\mathrm{Cr}$ em $\mathrm{mg} \mathrm{kg}^{-1}$ nas fraçōes superior, média e inferior da coluna de solo contaminada de um ano. 
O zinco nas colunas contaminadas apresentou maior concentração na fração superior quando comparado com as colunas branco de um ano e original. Nota-se uma diminuição na concentração de $\mathrm{Zn}$ na camada superior de 1119 para $985 \mathrm{mg} \mathrm{kg}^{-}$ 1. um enriquecimento nas fraçōes média e inferior, de 12 para $274 \mathrm{mg} \mathrm{kg}-1$ e de 4 para $22 \mathrm{mg} \mathrm{kg}^{-1}$, respectivamente, da coluna de seis meses para a de um ano. Isto pode indicar que o $\mathrm{Zn}$ esteja migrando para as camadas inferiores da coluna de solo. O zinco apresentou um aumento de concentração da coluna branco para a contaminada de um fator maior que 80 .

O manganês apresentou um comportamento semelhante ao zinco nas colunas contaminadas. As concentrações tendem a se acumular na camada superior e gradativamente diminuem em direção as camadas inferiores. Na coluna de seis meses encontraram-se valores $448 \mathrm{mg} \mathrm{kg}^{-1}$ na fração superior, $132 \mathrm{mg} \mathrm{kg}^{-1}$ na fração média, e $75 \mathrm{mg} \mathrm{kg}^{-1}$ na inferior. Na coluna contaminada de um ano as concentrações elevaram-se para $683 \mathrm{mg} \mathrm{kg}^{-1}$ na fração superior, reduziu-se para $46 \mathrm{mg} \mathrm{kg}^{-1}$ na fração média, e manteve-se em $75 \mathrm{mg} \mathrm{kg}^{-1}$ na fração inferior.

A seqüência decrescente de concentração parcial dos metais das colunas contaminadas seis meses e um ano apresentaram a mesma ordem:

$$
>\mathrm{Zn}>\mathrm{Mn} \geq \mathrm{Pb}>\mathrm{Cr}>\mathrm{Cu}>\mathrm{Ni}>\mathrm{Cd}
$$

A seqüência de concentração dos metais na coluna de solo contaminada apresentou uma mudança de ordem dos metais $\mathrm{Zn}$ e $\mathrm{Mn}$ em relação à seqüência das colunas de solo original e branco.

As porcentagens de disponibilidade dos metais $\mathrm{Pb}, \mathrm{Cd}, \mathrm{Zn}, \mathrm{Cu}, \mathrm{Ni}, \mathrm{Mn}$ e $\mathrm{Cr}$ no solo das colunas contaminadas de 6 meses e um ano por fração foram calculadas pela equação 5.1 e encontram-se nas FIG. 5.34. e 5.35.

Os metais $\mathrm{Zn}, \mathrm{Mn}$ e $\mathrm{Ni}$ apresentaram um aumento de disponibilidade nas colunas contaminadas em relação às colunas original e branco. 0 zinco e o manganês, metais de maior concentração nas pilhas zinco-carbono, foram os mais disponiveis nas colunas contaminadas de seis meses e de um ano 


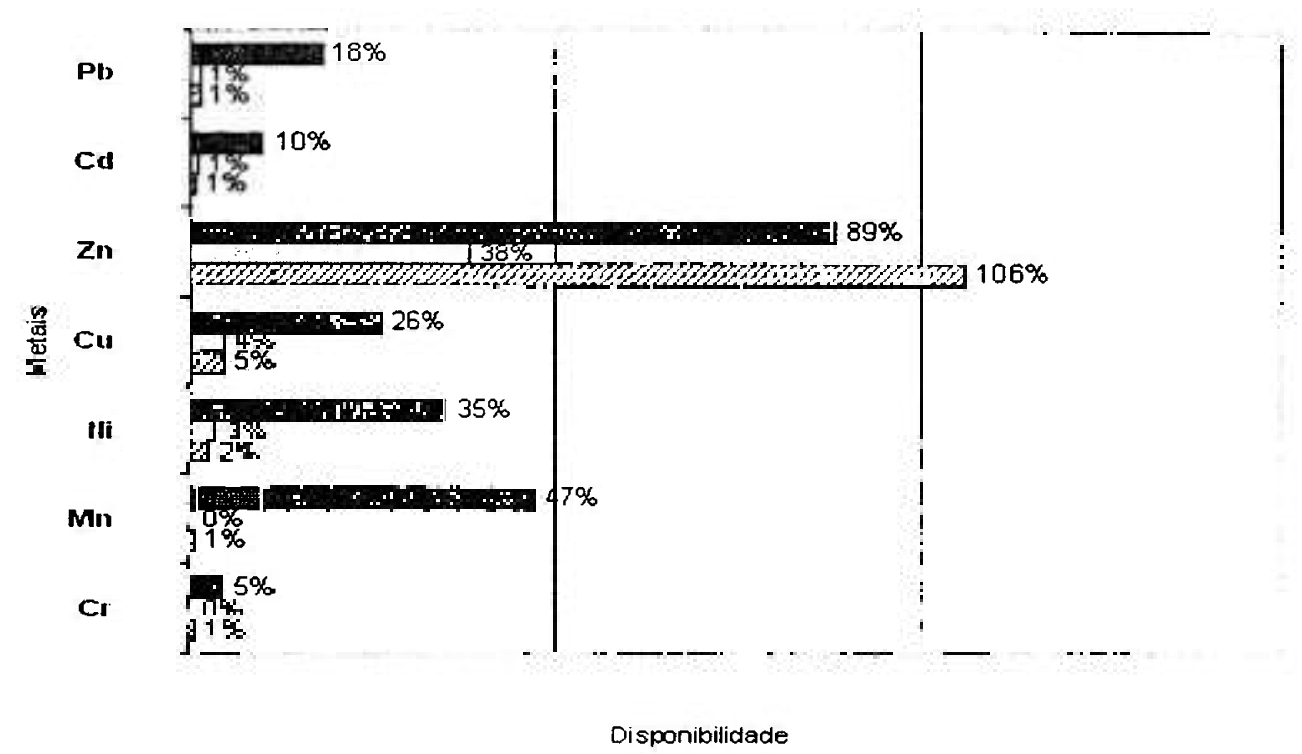

a Cont. fração inferior a Cort. fração média a Cont. fração superior

* Os valores de $\mathrm{Mn}$ e $\mathrm{Cr}$ na fração média estão abaixo de 0,001\%

FIGURA 5.34 - Porcentagem de disponibilidade dos metais $\mathrm{Pb}, \mathrm{Cd}, \mathrm{Zn}, \mathrm{Cu}, \mathrm{Ni}, \mathrm{Mn}$ e $\mathrm{Cr}$ das frações superior, média e inferior da coluna de Solo contaminada de seis meses.

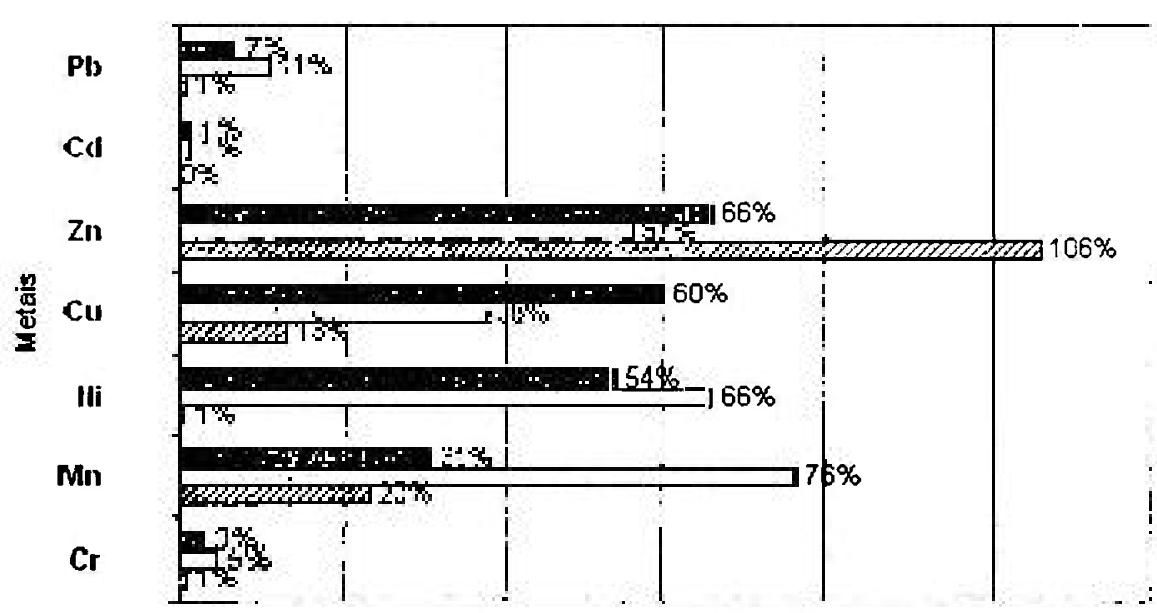

Porcentagem de disponibilidade \%

घ Cont. tração interior $\square$ Cort. tração média $\square$ Cont. fração superior

* O valor de Cd na fraçāo inferior está abaixo de $0,001 \%$

FIGURA 5.35 - Porcentagem de disponibilidade dos metais das frações superior, média e inferior da coluna de solo contaminada de um ano. 
A seqüência de disponibilidade (abaixo) na coluna de solo contaminada apresentou uma mudança de ordem dos metais $\mathrm{Zn}$, Mn e $\mathrm{Ni}$ em relação à seqüência das colunas de solo original e branco. Contaminantes recém introduzidos ao solo tendem a se manter móveis no solo quando o pH do solo está abaixo de 5 (Hellweg et al, 2005).

$$
>\mathrm{Zn}>\mathrm{Mn}>\mathrm{Ni}>\mathrm{Cu}>\mathrm{Pb}>\mathrm{Cd}>\mathrm{Cr}
$$

\subsubsection{Branco $x$ contaminada}

Para avaliar a massa total dos metais $\mathrm{Pb}, \mathrm{Cd}, \mathrm{Zn}, \mathrm{Cu}, \mathrm{Ni}, \mathrm{Mn}$ e $\mathrm{Cr}$ presente nas quatro colunas de solo, a massa foi obtida pela multiplicação da concentração do metal no solo conforme a fração $\left(\mathrm{mg} \mathrm{kg}^{-1}\right)$. TAB. A2, pela massa de solo da respectiva fração $(\mathrm{kg})$, TAB. A4. Os resultados foram apresentados na TAB. 5.3.

TABELA 5.3 - Massa (mg) dos metais $\mathrm{Pb}, \mathrm{Cd}, \mathrm{Zn}, \mathrm{Cu}, \mathrm{Ni}, \mathrm{Mn}$ e $\mathrm{Cr}$ encontrados nas frações (superior, média e inferior) das 4 colunas de solos.

\begin{tabular}{|c|c|c|c|c|c|c|c|}
\hline Masssa (mg) & $\mathrm{Cr}$ & $\mathrm{Mn}$ & $\mathrm{Ni}$ & $\mathrm{Cu}$ & $\mathrm{Zn}$ & $\mathrm{Cd}$ & $\mathrm{Pb}$ \\
\hline Original Fraçāo Superior & 2,25 & 2,13 & 0,15 & 0,19 & 0,50 & 0,14 & 6,54 \\
\hline Original Fraçāo Média & 4,47 & 2,16 & $>L D$ & 0,32 & 3,14 & 0,24 & 10,66 \\
\hline Original Fraçāo Inferior & 5,95 & 4,55 & 0,05 & 0,31 & 1,02 & 0,48 & 16,04 \\
\hline Total & 12,67 & 8,84 & 0,20 & 0,82 & 4,66 & 0,86 & 42,08 \\
\hline Branco Fraçāo Superior 1 ano & 2,46 & 1,52 & 0,02 & 0,71 & 0,97 & 0,17 & 6,53 \\
\hline Branco Fraçāo Média 1 ano & 3,18 & 5,18 & $>L D$ & 0,83 & 2,07 & 0,20 & 9,20 \\
\hline Branco Fração Inferior 1ano & 5,75 & 3,51 & 0,04 & 0,79 & 0,89 & 0,37 & 15,33 \\
\hline Total & 11,39 & 10,20 & 0,06 & 2,34 & 3,94 & 0,73 & 31,06 \\
\hline Cont. Fraçāo Superior 6 meses & 1,20 & 75,18 & 0,64 & 0,47 & 188,00 & 0,17 & 4,33 \\
\hline Cont. Fraçāo Média 6 meses & 19,37 & 43,67 & 2,71 & 3,82 & 3,97 & 3,04 & 100,06 \\
\hline Cont. Fraçāo Inferior 6 meses & 19,42 & 24,56 & 2,75 & 3,92 & 1,42 & 3,01 & 100,97 \\
\hline Total & 39,99 & 143,42 & 6,10 & $\mathbf{8 , 2 1}$ & 193,38 & 6,22 & 205,36 \\
\hline Cont. Fraçāo Superior 1 ano & 3,22 & 109,95 & 0,96 & 0,93 & 158,58 & 0,25 & 9,13 \\
\hline Cont. Fração Média 1 ano & 4,32 & 15,02 & $>L D$ & 2,20 & 87,56 & 0,28 & 10,20 \\
\hline Cont. Fraçāo Inferior 1 ano. & 23,70 & 29,78 & 3,99 & 4,80 & 8,70 & 3,90 & 124,48 \\
\hline Total & 31,24 & 154,74 & 4,95 & 7,93 & 254,84 & 4,43 & 143,80 \\
\hline
\end{tabular}


De um modo geral, as massas calculadas mostraram que a quantidade dos metais presentes na coluna original e branco foi semelhante. A massa das colunas contaminadas de 6 meses apresentou valores ligeiramente maiores que os de 1 ano para alguns metais, provavelmente devido ao escoamento lento da coluna de 6 meses (discutido no item 5.3.3). A subtração da massa acumulada da coluna contaminada da coluna branco mostrou um incremento acentuado nas massas dos metais no solo, principalmente de $\mathrm{Zn}, \mathrm{Mn}$ e $\mathrm{Pb}$.

\subsection{Avaliação da contaminação ambiental}

\subsubsection{Contribuição da pilha por balanço de massa}

Para verificar qual foi a contribuição da pilha quanto ao aumento das concentraçōes do $\mathrm{Pb}, \mathrm{Cd}, \mathrm{Zn}, \mathrm{Cu}, \mathrm{Ni}, \mathrm{Mn}$ e $\mathrm{Cr}$ nas colunas de solo, a massa total dos metais nos efluentes (TAB. 5.2) foram somadas a massa total dos metais no solo (TAB. 5.3) de suas respectivas colunas. Como a coluna branco de seis meses foi descartada (item 5.4), trabalhou-se somente com os dados da coluna de um ano. A seguir foi calculada a diferença entre a somatória das massas das colunas branco e contaminada para cada metal, e assim obter a contribuição de metais provenientes das pilhas na coluna contaminada.

A TAB. 5.4 apresenta a massa total do efluente+solo para cada uma das colunas lixiviadas (branco e contaminada), além da massa do metal introduzida na coluna de solo devido as pilhas.

As seqüências decrescentes da massa total efluente+solo encontradas para as colunas branco, contaminada e para a contribuição da pilha foram:

$>$ Colunas branco: $\quad \mathrm{Pb}>\mathrm{Cr} \geq \mathrm{Mn}>\mathrm{Zn}>\mathrm{Cu}>\mathrm{Cd}>\mathrm{Ni}$

$>$ Colunas contaminadas: $\mathrm{Zn}>\mathrm{Mn}>\mathrm{Pb}>\mathrm{Cr}>\mathrm{Cu}>\mathrm{Ni} \geq \mathrm{Cd}$

$>$ Contribuição da pilha: $\mathrm{Zn}>\mathrm{Mn}>\mathrm{Pb}>\mathrm{Cr}>\mathrm{Cu} \geq \mathrm{Ni}>\mathrm{Cd}$ 
Tabela 5.4 - Massa total $(\mathrm{mg})$ acumulada dos metais no efluente e no solo das colunas branco e contaminada de um ano e a contribuição da pilha.

\begin{tabular}{lccc}
\hline \multicolumn{3}{c}{ Efluente+solo da coluna de um ano $(\mathrm{mg})$} \\
\hline Metais & Branco & Contaminada & Contribuição da pilha \\
$\mathrm{Cr}$ & 11,44 & 31,34 & 19,90 \\
$\mathrm{Mn}$ & 10,34 & 198,92 & 188,57 \\
$\mathrm{Ni}$ & 0,10 & 5,25 & 5,15 \\
$\mathrm{Cu}$ & 2,59 & 8,01 & 5,42 \\
$\mathrm{Zn}$ & 4,84 & 386,68 & 381,85 \\
$\mathrm{Cd}$ & 0,74 & 4,45 & 3,71 \\
$\mathrm{~Pb}$ & 31,24 & 144,30 & 113,06 \\
\hline
\end{tabular}

A seqüência dos metais da soma efluente+solo da coluna contaminada foi semelhante à seqüência encontrada para a concentração parcial dos metais no solo da mesma coluna (item 5.4.3) e da seqüência de lixiviação das pilhas (item 5.2), confirmando que $\mathrm{Zn}, \mathrm{Mn}$ e $\mathrm{Pb}$ são os metais da pilha que mais contribuem para a contaminação ambiental.

Provavelmente o periodo de lixiviação de um ano, não foi suficiente para lixiviar toda concentração de metais presente nas três pilhas. Zinco, manganês e chumbo foram os metais que apresentaram maior elevação de sua massa na coluna contaminada quando comparada com a coluna branco. A massa obtida de zinco e manganês já era esperada, pois estes metais representam $48 \%$ em peso das pilhas zinco-carbono (Hurd et al, 1993). O zinco foi mais lixiviado que manganês na coluna contaminada, provavelmente devido a sua espécie quimica. $Z n$ está na forma de sal de cloreto de zinco na pasta eletrolitica da pilha e, portanto, foi mais facilmente ionizado em solução.

\subsubsection{Fator de contaminação}

A contaminaçāo causada pelo descarte inadequado de pilhas à qualidade do solo pode ser calculada pelo seu fator de contaminação. Este fator de contaminação é calculado pela razão da massa acumulada solotefluente da coluna contaminada pela da coluna branco (TAB. 5.4). Os resultados dos fatores de contaminação (FC) para cada metal encontram-se na TAB. 5.5. 
Tabela 5.5. - Fator de Contaminação (FC) da coluna contaminada.

\begin{tabular}{llllllll}
\hline & $\mathrm{Cr}$ & $\mathrm{Mn}$ & $\mathrm{Ni}$ & $\mathrm{Cu}$ & $\mathrm{Zn}$ & $\mathrm{Cd}$ & $\mathrm{Pb}$ \\
\hline $\mathrm{FC}$ & 2,7 & 19 & 53 & 3,1 & 80 & 6.0 & 4,6 \\
\hline
\end{tabular}

Os fatores de contaminação da TAB. 5.5 foram colocados em seqüência decrescente:

$$
>\mathrm{Zn}>\mathrm{Ni}>\mathrm{Mn}>\mathrm{Cd}>\mathrm{Pb}>\mathrm{Cu}>\mathrm{Cr}
$$

O fator de contaminação indica o grau de alteração da concentração do metal no solo original. O Ni apresentou um elevado FC assim como de $\mathrm{Zn}$ e $\mathrm{Mn}$. O FC de $\mathrm{Cd}$ e $\mathrm{Pb}$ são semelhantes e aproximadamente 3 vezes menor que o do $\mathrm{Mn}$.

\subsubsection{Estimativa da porcentagem de lixiviação dos metais da pilha}

Para estimar a porcentagem de metais lixiviados da pilha pelo ensaio de lixiviação da coluna de solo+piha por uma solução "água de chuva" é necessário conhecer a massa destes na composição da pilha. A literatura apresenta vários trabalhos sobre a composição da pilha, onde $\mathrm{MnO}_{2}$ está presente numa proporção de $29,5 \%, \mathrm{ZnCl}_{2}$ de $6 \%$ e $\mathrm{Zn}^{\circ}$ de $9 \%$ em peso na pilha (item 3.1).

Com base nos dados da composição de metais de $\mathrm{Zn}\left(\mathrm{Zn}^{\circ}+\mathrm{ZnCl}_{2}\right)$ e $\mathrm{Mn}$ $\left(\mathrm{MnO}_{2}\right)$ na pilha e a massa total da pilha $(17,8 \mathrm{~g})$ calculou-se a massa em $\mathrm{Zn}$ e $\mathrm{Mn}$ presente na pilha. Dados na literatura de $\mathrm{Cd}$ e $\mathrm{Pb}$ na pilha variam muito, portanto optou-se utilizar para $\circ \mathrm{Cd}$ e $\mathrm{Pb} \circ$ valor limite estabelecido pela Resolução 257 (CONAMA, 1999) $0,015 \%$ e $0,200 \%$ em peso na pilha, respectivamente. Estas porcentagens foram utilizadas para o cálculo da massa de $\mathrm{Cd}$ e $\mathrm{Pb}$ na pilha.

A TAB. 5.6 apresenta a massa $(\mathrm{mg})$ dos metais em 3 pilhas a partir de dados da composição da pilha. A porcentagem de lixiviação do metal da pilha foi calculado pela relação massa do metal em 3 pilhas com a massa total do metal média 
(contribuição da pilha) obtida na TAB 5.4. No ensaio das colunas de solo foram usadas 3 pilhas, portanto a massa de $\mathrm{Mn}$ correspondente das pilhas adicionadas no topo da coluna foi de $9522 \mathrm{mg}$ de $\mathrm{Mn}$ e $11688 \mathrm{mg}$ de $\mathrm{Zn}$.

A TAB. 5.6 mostrou que somente $3,3 \%$ do $\mathrm{Zn}$ e 2,0 \% do Mn presente na pilha foram lixiviados pela solução "água de chuva". Estes resultados mostraram que somente uma pequena porção do $\mathrm{Zn}$ e $\mathrm{Mn}$ foi removida da pilha. $\mathrm{O} \mathrm{Zn}$ foi mais facilmente lixiviado do que o $\mathrm{Mn}$, o que era esperado, já que o $\mathrm{Zn}$ encontra-se na pasta eletrolitica na forma de $\mathrm{ZnCl}_{2}$ espécie facilmente mobilizada pela soluçāo "água de chuva". O $\mathrm{Zn}^{\circ}$ do ânodo provavelmente seja lixiviado bem mais lentamente que o $\mathrm{ZnCl}_{2}$ pela solução "água de chuva".

No entanto uma análise da porcentagem de lixiviação dos metais $\mathrm{Cd}$ e $\mathrm{Pb}$ mostraram que estes dois metais foram muito lixiviados da pilha. $\mathrm{O} \mathrm{Pb}$ apresentou valores acima de $100 \%$. Os valores estabelecidos para Cd e Pb na Resolução 257 (CONAMA, 1999) referem-se à composição da pilha, mas não deixa claro se a porcentagem proposta se refere à pilha total, isto $\dot{e}$, pilha+invólucro ou somente a parte interna pilha. Como a base de cálculo para a porcentagem de lixiviação do $\mathrm{Pb}$ foi o valor do CONAMA/1999, que representa o teor máximo permitido de $\mathrm{Pb}$ para a fabricação da pilha e assumindo que a porcentagem seja o valor relativo à parte interna da pilha, pode-se supor que provavelmente este excesso de $\mathrm{Pb}$ encontrado poderia provir do invólucro da pilha. O valor da porcentagem de lixiviação do $\mathrm{Cd}$ também foi considerado alto.

\subsubsection{Comparação com os valores CETESB}

No Estado de São Paulo, a Companhia de Tecnologia de Saneamento Ambiental do Estado de São Paulo (CETESB) tem a atribuição legal de proteger a qualidade dos solos e da água subterrânea e controlar a poluição de áreas contaminadas e suspeitas de contaminação. 
Tabela 5.6 - Cálculo da porcentagem de lixiviação dos metais das pilhas pela solução "água de chuva".

\begin{tabular}{lccc}
\hline Metal & Metal em 3 pilhas $\mathrm{mg}$ & Contribuiçăo da pilha $\mathrm{mg}$ & \% Lixiviação da pilha \\
\hline $\mathrm{Mn}$ & 9522 & 189 & 2,0 \\
$\mathrm{Zn}$ & 11688 & 382 & 3,3 \\
$\mathrm{Cd}$ & 8,01 & 3,7 & 46,2 \\
$\mathrm{~Pb}$ & 106,8 & 113 & $>100$ \\
\hline
\end{tabular}

\subsubsection{Avaliação da contaminação do solo}

Um solo está contaminado por um metal quando a concentração deste está acima de valores naturais do solo da área estudada, ou dos valores estabelecidos por agências ambientais referentes a solos limpos (ou solos que não sofreram impacto ambiental devido as atividade antrópicas), ou quando a concentração do metal esta acima de valores naturais mundiais.

A avaliação de um solo suspeito de contaminação que pode provocar risco à saúde humana é importante para se decidir o uso e ocupação deste solo. Para identificar este solo contaminado é necessário comparar as concentrações obtidas das substâncias no diagnóstico do solo com os valores de intervençāo (que indicam o nivel de contaminação acima do qual existe risco potencial a saúde humana) estabelecidos pela CETESB, 2005.

A existência de uma área contaminada pode gerar problemas como danos à saúde humana, comprometimento da qualidade dos recursos hidricos, restriçōes ao uso do solo e danos ao patrimônio público e privado, com a desvalorização das propriedades, além de danos ao meio ambiente. Assim, a concentração parcial dos metais $\mathrm{Pb}, \mathrm{Cd}, \mathrm{Zn}, \mathrm{Cu}, \mathrm{Ni}, \mathrm{Mn}$ e $\mathrm{Cr}$ das colunas contaminadas (FIG. 5.32 e 5.33) foram comparados com os valores orientadores (referência, intervenção) para solos no Estado de São Paulo (CETESB, 2005) e os valores mundiais (TAB. 5.7). 
TABELA 5.7 - Valores orientadores (referência, intervenção) ${ }^{*}$, valores mundiais ${ }^{* *} \mathrm{e}$ intervalo de concentração de metais no solo da coluna contaminada $\left(\mathrm{mg} \mathrm{kg}^{-1}\right)$.

\begin{tabular}{lcccc}
\hline Metais & \multicolumn{2}{c}{ CETESB $^{*}$} & McBride $^{\star *}$ & Experimental \\
\hline Cádmio & Referência & Intervenção & Mundial & Conc.parcial \\
Chumbo & $<0,5$ & 3 & $0,06-1,1$ & $1-10$ \\
Manganês & 17 & 120 & $10-84$ & $26-314$ \\
Niquel & - & - & $80-1300$ & $47-683$ \\
Zinco & 13 & 50 & $4-55$ & $4-10$ \\
Cromo & 60 & 500 & $17-125$ & $4-1119$ \\
Cobre & 40 & 150 & $7-221$ & $7-60$ \\
\hline
\end{tabular}

negrito:valores que ultrapassam o valor de intevenção.

Fonte - * CETESB (2005) **McBride(1994)

$\mathrm{Zn}, \mathrm{Pb}$ e $\mathrm{Cd}$ apresentaram concentrações parciais em alguma das camadas de solo da coluna contaminada maiores que os valores de referência e de intervenção da CETESB e acima dos valores mundiais. Os metais $\mathrm{Ni}, \mathrm{Cr}$ e $\mathrm{Cu}$ apresentam concentrações igual ou abaixo do valor referência e dentro do intervalo dos valores mundiais. $\mathrm{O} \mathrm{Mn}$ apresenta valores dentro do intervalo dos valores mundiais, mas não há valores orientadores da CETESB estabelecidos.

\subsubsection{Avaliação da contaminação da água subterrânea}

A concentração mínima, máxima e a média mensal dos efluentes obtida nas duas colunas branco e contaminada encontram-se na TAB. 5.8. Os valores de intervenção para águas subterrâneas estabelecidos pela CETESB (2005) foram inseridos na tabela para facilitar a sua comparação com os valores experimentais.

Para identificar a contaminação de uma água subterrânea é necessário comparar as concentrações obtidas das substâncias no diagnóstico da água subterrânea com os valores estabelecidos pela CETESB (2005) com base no padrão da potabilidade de água (Ministério da Saúde, Portaria 518 de 26, de março de 2004). 
TABELA 5.8 - Mínimo, máximo, média mensal das concentrações dos efluentes das quatro colunas (branco, contaminada, seis meses e um ano) e os valores orientadores de água subterrânea da CETESB* (2005).

\begin{tabular}{|c|c|c|c|c|c|c|c|c|}
\hline & Concentração $\mathrm{mg} \mathrm{L}^{-1}$ & $\mathrm{Zn}$ & $\mathrm{Mn}$ & $\mathrm{Pb}$ & $\mathrm{Ni}$ & $\mathrm{Cd}$ & $\mathrm{Cu}$ & $\mathrm{Cr}$ \\
\hline \multirow{3}{*}{ Colunas branco } & Minimo & 0,10 & 0,004 & 0,020 & 0,006 & 0,0002 & 0,007 & 0,011 \\
\hline & Máxima & 0,41 & 0,049 & 0,076 & 0,017 & 0,004 & 0,008 & 0,019 \\
\hline & Média Mensal & 0,22 & 0,027 & 0,036 & 0,008 & 0,002 & 0,008 & 0,012 \\
\hline \multirow{3}{*}{$\begin{array}{l}\text { Colunas } \\
\text { Contaminadas }\end{array}$} & Mínimo & 0,23 & 0,423 & 0,029 & 0,012 & 0,0003 & 0,007 & 0,012 \\
\hline & Máxima & 323 & 144 & 0,281 & 0,159 & 0,019 & 0.041 & 0,038 \\
\hline & Média Mensal & 77.7 & 33,1 & 0,144 & 0,070 & 0,008 & 0,019 & 0,024 \\
\hline CETESB* & Intervenção & 5,00 & 0,400 & 0,010 & 0,020 & 0,005 & 2,000 & 0,050 \\
\hline
\end{tabular}

Fonte-CETESB. 2005.

No presente trabalho o efluente representa a solução do solo e não a água subterrânea, pois as colunas de solo estudadas foram coletadas logo abaixo do topo do solo e distante do lençol freático (água subterrânea). A comparação da concentração dos metais do efluente com os valores de intervenção para água subterrânea (TAB. 5.8) não pode ser direta, pois os metais do efluente (solução do solo) poderiam ser adsorvidos e sofrer interações com as diversas camadas do solo existentes durante o percurso, ou seja, sofrer atenuação natural do solo e consequentemente apresentarem uma concentração menor na água subterrânea. A CETESB (2001) adotou um fator de atenuação igual a 10 (ou seja, a concentração do contaminante na água subterrânea será 10 vezes menor do que a sua concentração na solução do solo) quando estabeleceu os valores de intervenção para solos.

Portanto, se for aplicado o fator de atenuação 10 aos valores da concentração dos metais obtidos nos efluentes das colunas de solo (TAB. 5.8) observa-se que a concentração média mensal dos metais $\mathrm{Zn}, \mathrm{Mn}$ e $\mathrm{Pb}$ das colunas contaminadas ainda ultrapassam o valor de intervenção para águas subterrâneas estabelecido pela CETESB (2005). Esta avaliação dos efluentes das colunas de solo contaminadas pelas pilhas pode indicar que 0 descarte inadequado de pilhas $\mathrm{Zn} /$ carbono no solo 
pode vir a causar uma contaminação da água subterrânea, dependo das características do solo ao longo do perfil.

\subsubsection{Conclusão da avaliação da contaminação}

A avaliação da contaminação pelos dados do balanço de massa (solo+efluente) fornece indicação dos metais da pilha que podem causar aumento da concentração destes no solo original. A seqüência da contribuição da pilha a seguir (item 5.5.1) mostra que $\mathrm{Zn}, \mathrm{Mn}$ e $\mathrm{Pb}$ são os contaminantes potenciais.

$$
>\mathrm{Zn}>\mathrm{Mn}>\mathrm{Pb}>\mathrm{Cr}>\mathrm{Cu}>\mathrm{Ni} \geq \mathrm{Cd}
$$

Se a avaliação fosse feita pelo fator de contaminação a seqüência a seguir (item 5.5.2) sugere que $\mathrm{Ni}$ representa a maior preocupação em termos de alteração da concentração original do solo, seguidos de $\mathrm{Zn}, \mathrm{Mn}$ e $\mathrm{Pb}$.

$$
>\mathrm{Ni}>\mathrm{Zn}>\mathrm{Mn}>\mathrm{Pb}>\mathrm{Cd}>\mathrm{Cu}>\mathrm{Cr}
$$

Cabe discutir o significado do fator de contaminação do Ni. De acordo com a literatura Ni pode estar presente $0,007 \%$ na pasta eletrolítica (Salgado, 2001) e na chapa de aço niquelada do invólucro, logo $\mathrm{Ni}$ provavelmente está presente em quantidades pequenas na pilha, seu alto fator de contaminação se deve provavelmente a baixa concentração de $\mathrm{Ni}$ no solo original e/ou abaixo dos valores referência CETESB, 2005. A concentração de $\mathrm{Ni}$ encontrada no solo foi muito menor que o valor intervenção CETESB, e portanto, Ni não deveria ser considerado um metal preocupante.

A avaliação com base nos valores orientadores (referência $\mathrm{e}$ intervenção) da CETESB, 2005, (item 5.5.4) aponta que o solo em estudo pode estar contaminado por metais como $\mathrm{Zn}, \mathrm{Pb}$ e $\mathrm{Cd}$. $\mathrm{O} \mathrm{Mn}$ foi apontado em todas as avaliações como potencialmente contaminante, mas não pode ser avaliado pelo critério da CETESB, já que Mn não é contemplado pela legislação. A avaliação do efluente com base nos valores de intervenção estabelecidos pela CETESB para água subterrânea aponta para possiveis problemas de contaminação da água subterrânea para os metais $\mathrm{Zn}, \mathrm{Mn}$ e $\mathrm{Pb}$. 
A estimativa da porcentagem de lixiviação dos metais da pilha indicou que $\mathrm{Zn}$ e Mn presentes na pilha foram pouco lixiviados ( $<5 \%)$ pela solução "água de chuva" durante um ano (item 5.5.3). Teoricamente os demais metais também deveriam ser lixiviados na mesma proporção. A estimativa de $\mathrm{Cd}$ e $\mathrm{Pb}$ aponta para porcentagens de lixiviação bem mais altas, isto pode indicar que o valor adotado como a possivel quantidade do metal na composição da pilha não corresponda ao valor real na pilha usada neste experimento ou outros fatores ( $\mathrm{Cd}$ e $\mathrm{Pb}$ presentes no invólucro da pilha ou como impureza em outros componentes da pilha) podem estar contribuindo para a contaminação de $\mathrm{Cd}$ e $\mathrm{Pb}$ no sistema em estudo. $\mathrm{O}$ estudo de pilhas de Hinrichs.e Soares (2001), citado do item 3.1, também encontrou altas concentrações de $\mathrm{Cd}$ e $\mathrm{Pb}$ na pasta eletrolítica da pilha. É conhecido que o minério de $\mathrm{Zn}$ vem geralmente acompanhado de Cd como impureza (Souza, 2003)

As várias formas de avaliação sobre uma possivel contaminação apontam que o descarte de pilhas de $\mathrm{Zn} /$ carbono no solo pode causar uma contaminação significativa do solo para os metais $\mathrm{Zn}, \mathrm{Mn}$ e $\mathrm{Pb}$ e possivelmente também para $\mathrm{Cd}$. Esta contaminação do solo poderia vir a causar uma contaminação da água subterrânea para os metais $\mathrm{Zn}, \mathrm{Mn}$ e $\mathrm{Pb}$, dependo das características do solo ao longo do perfil. 


\section{CONCLUSĀO}

O estudo da lixiviação de pilhas $\mathrm{Zn} /$ carbono sobre uma coluna solo por uma solução "água de chuva" $(\mathrm{pH} 4)$ pode causar uma contaminação significativa do solo para os metais $\mathrm{Zn}, \mathrm{Mn}$ e $\mathrm{Pb}$ e possivelmente também para $\mathrm{Cd}$. Esta contaminação do solo poderia vir a causar uma contaminação da água subterrânea para os metais $\mathrm{Zn}$, $\mathrm{Mn}$ e $\mathrm{Pb}$, dependo das caracteristicas do solo ao longo do perfil.

Observou-se também que a contaminação de $\mathrm{Zn}$ e $\mathrm{Mn}$ tende a migrar da camada superior da coluna de solo para as camadas inferiores com o tempo (6 meses e 1 ano) de lixiviação com a solução "água de chuva", podendo aumentar o risco de contaminação da água subterrânea. 
7 Referências Bibliográficas.

ADPIANO. D.C. Trace elements in the terrestrial environment. New York. SoringerVeriag: 1986 .

AFONSO ET AL. Processamento da pasia eletrolitica de pithas usadas Quim. Nova. v. 26 ก. ${ }^{\circ}$. p $573-577,2003$

AGVISELABS - WWW agviselabs.com acesso em 2/11/2005.

AMARANTE. ANDREA. Comportamento geoquimico de metais pesados em sedimentos argilosos da bacia de São Paulo, Suzano-SP. 1997. 98 f. Disssertação (mestrado em Geoquimica e Geotectônica) - instituto de Geociências, Universidade de São Paulo

ALLOWAY, B.J. Heavy Metals in Soils. Glascow. Blackie Academic and Professional, 1995.

APPELO. C. A.; POSTMA, D. Geochemistry, Groundwater, and Pollution. Daukema. Brookfield. 1993

ASSOCIACTAOO BRASILEIRA DE INORMAS TECINICAS - ABNT através da noma NBR $7039 / 87$.

ASSOCIAÇÃO BRASILEIRA DA INDUSTRIA ELÉTRICA E ELETRÓNICA - ABINEE. www abinne.gov br acesso em 15/04/2004.

BERNER, E.K. \& BERNER, R.A. The global water circle: geochemistry and environment. New Jersey, Prentice-Hall. 1987. 
DAUGA, CHRISTINE. Impacto da disposição de um residuo industrial rico em metais pesados ( $\mathrm{Mn}, \mathrm{Cu}, \mathrm{Pb}, \mathrm{Zn}$ ) e $\mathrm{Mg}$ sobre uma cobertura ferralitica em clima tropical (SP. Brasil): mineralogia, petrografia e transferèncias geoquimicas. 2000. 233f. Disseriação (Doutorado em Geoquimica a Gectectònica) - Instituto de Geociências. Iniversidade de São Paulo.

DELL. R. M. Batteries fifty years of materials development. Solid State lonics, $v$. 134, $p$ 139-158, 2000 .

EMPRESA BRASILEIRA DE PESQUISA AGROPECUÁRIA - EMBRAPA. Sistema brasileiro de classificação de solos. Rio de janeiro. EMBRAPA - Produção de Informaçăo $\$ 999$.

FORNARO. A.: GUTZ. IVANO Variação temporal da composiçāo iónica de águas de chuva da cidade de São Paulo, diferenças de 1989-1990 para 2000. XXV Reunião Anual da Sociedade Brasileira de Quimica, Poços de Caldas. Livro de Resumos, $p$ AB085, 2002.

FREEZE. … A CHERRY. J. A. Groundwater. New Jersey, Prentice-Hall, 1979.

GALVÃO. FATRICIA Chuva ácida: estudo de caso no campus USP/SP. 1996. $95 \mathrm{f}$. Dissentação (Mestrado em Recursos Minerais e Hidrogeologia) - instituto de Geociencias Universidade de São Paulo.

INSTITUTO BRASILEIRO DE GEOGRAFIA E ESTATISTICA -IBGE. WwW ibge gOV.bI acesso em. 30/01/2006.

INSTITUTO NACIONAL DE METEREOLOGIA - INMET, www inmet.gOv.br aCesSO em $12 / 09 / 2003$. 
ISHIMINE. VINIC!US. Avaliação hidrogeológica e hidrogeoquímica em área contaminada por manganês na Região de Suzano-SP Cisssertação (mestrado em Recursos Minerais a Hidrogeologia) - Instituto de Geocièncias, Universidade de São Paulo, 1998.

HANSEM, B. K: POSTMA, D. Acidification, buffering, and sait effects in the unsatured zone of sandy. Water Resources Research vol. 31, n. 11, 1995

HELLWEG, S.: FISCHER, U: HOFSTETTER, T. B.: HUNGERBÜHLER, K. Sitedependent fate assessment in LCA: transpor of heavy metals in soil. J. Cleaner Production, $v .13$, p. 341-361, 2005.

HEWITT, A. D.: REYNOLDS, C. M. Dissolution of metais from soils and sediments with a microwave/nitric acid digestion technique. Spectroscopy. v. 11. p. 187-192, 1990.

HINRICHS, RUTH: SOARES, PAULA. Análise de metais pesados em pilhas. VII Congresso Brasileiro de Geoquimica, 2001. VIII Congresso Brasileiro de Geoquímica. Cuntiba 21-26 de Outubro 2001

HURD, DAVIO \&. ET AL. Recyncling of consumer dry cell batteries. New York. Noyes Data Corporation. 1993.

KABATAS-PENDIAS, A. \& PENDIAS, H. Trace elements in soils and plants. Boca Raton, CRC Press, 1992.

KLUTE, A. Methods of soil anafysis. Physical and mineralogical methods. Madison. 1992.

LEPSCH, IGO F. Formação e consenação de solos. Sāo Paulo. Oficina de Textos. 2002. 
MACLEAN. J.: BLEDSCE. 3. Behavior of metals in soils. USEPA-United States Enviromental Protection Agency, EPA1540/S-92/018 Ground Water issue, October 1992.25p.

MCBRIDE. MURPAY E. Environmental chemistry of soils. Exiord. Oxford University Press, 1994.

MELLO JUNIOR, RIVALLOO FRANÇA DE. Geoquimica da contaminaçäo industrial do solo e do subsolo por metais pesados na regiāo de Suzano-SP. 1998. $113 \mathrm{f}$. Dissertação (Mestrado em Geoquimica e Geotectônica; - Insthuto de Geociências. Universidade de São Faulo.

MONIZ ET AL. ANTONIO C. Elementos de pedologia. Sミ̄o Pauio. Editora Poligono. 1972.

SALGADO ET AL. Recovery zinc and manganese from spent alkaline liquid-liquid extraction with Cyanex 272. J. Power Sources, v. 115, 2003.

SIGOLO, JOEL BARBUUIANI. Aplicação da geoquimica de superficie na análise da mobilidade e concentração de metais pesados em ambiente tropical. 1998. 216 f. Tese (Livre Docencia em Geoquimica de Superficie) - instituto de Geociências, Universidade de São Paulo.

SILVEIRA, M. L; ALLEONI, L. R. Adsorção do cobre em solos paulistanos com diferentes graus de intemperismo. 1999. Dissertação (mestrado) ESALQ, Universidade de São Paulo.

Souza, Cleusa Cristina Bueno Martha de. Aplicação de processos hidrometalúrgicos na reciclagem de pithas. 2003. Tese (Doutorado em Engenharia Metalürgica e Materiais) - Escola Poittécnica, Universidade de São Paulo. 
SOUZA, C: TENORIO, ¿. LXWlaçà àcida de pithas akalinas a zinco carbono usadas. VI Soutrhern Hemisphere Meeting on Mineral Technology and XVIII Brazilian Meeting on Mineral Dressing and Extractive Metallurgy. Rio de Janeiro $27 / 5$ a $1 / 6$. 2001.

SPARKS, D. L. Environmental chemistry. San Diego. Sorption chenomena on soils, 1995.

SPOSITO, GARRISON. The chemistry of soils. New York, Oxford University Press, 1989.

Oliveira et al. Joāo Bertoldo. Classes Gerais de solos no Brasill.1992. Editora jaboticabal. 
APÊNDICE TABELA A1 - Concentrações * em $\mathrm{mg} \mathrm{L}^{-1}$ dos metais nos efluentes quatro colunas lixiviadas.

\begin{tabular}{|c|c|c|c|c|c|c|c|c|}
\hline Amostras (mg $\left.L^{-1}\right)$ & Período & $\mathrm{Cr}$ & $\mathrm{Mn}$ & $\mathrm{Ni}$ & $\mathrm{Cu}$ & $2 n$ & $\mathrm{Cd}$ & $\mathrm{Pb}$ \\
\hline \multirow{6}{*}{$\begin{array}{l}1 .^{\circ} \\
\text { Coluna } \\
\text { Branco } \\
\text { Periodo de } 6 \text { meses }\end{array}$} & Junho & 0,0106 & 0,0038 & 0,0079 & 0,0083 & 0,2286 & 0,0006 & 0,0242 \\
\hline & Julho & 0,0106 & 0,0219 & 0,0079 & 0,0083 & 0,2286 & 0,0011 & 0,0249 \\
\hline & Agosto & 0,0106 & 0,0218 & 0,0079 & 0,0083 & 0,2286 & 0,0006 & 0,0244 \\
\hline & Setembro & $\overline{0,0106}$ & 0,0075 & 0,0079 & 0,0083 & 0,2286 & 0,0013 & 0,0242 \\
\hline & Outubro & 0,0106 & 0,0040 & 0,0079 & 0,0083 & 0,2286 & 0,0010 & 0,0242 \\
\hline & Novembro & 0,0106 & 0,0177 & 0,0079 & 0,0083 & 0,2286 & 0,0015 & 0,0488 \\
\hline & & & & & & & & \\
\hline \multirow{12}{*}{$\begin{array}{l}2 .^{\circ} \\
\text { Coluna } \\
\text { Branco } \\
\text { Período de um ano. }\end{array}$} & Junho & 0,0106 & 0,0500 & 0,0079 & 0,0083 & 0,2286 & 0,0018 & 0,0273 \\
\hline & Julho & 0,0106 & 0,0257 & 0.0079 & 0,0083 & 0,2286 & 0,0026 & 0,0340 \\
\hline & Agosto & 0,0106 & 0,02 & 0,0079 & 0,0083 & 0,2286 & 0,0022 & 0,0467 \\
\hline & Setembro & 0,0106 & 0,0138 & 0,0079 & 0,0083 & 0,2286 & 0,0027 & 0,0386 \\
\hline & Outubro & 0,0119 & 0,0490 & 0,0091 & 0,0083 & 0,2729 & 0,0032 & 0,0761 \\
\hline & Novembro & 0,0119 & & 0,0168 & & 0,4121 & & 0,0624 \\
\hline & Dezembro & 0,0106 & 0,0458 & 0,0119 & 0,00 & 0,2286 & 0,0026 & 0,0539 \\
\hline & Janeiro & 0,0106 & 0,0286 & 0,0113 & 0,0083 & 0,2286 & 0,0030 & 0,0546 \\
\hline & Fevereiro & 0,0186 & 0,0157 & 0,0061 & 0,0068 & 0,1641 & 0,0002 & 0,0280 \\
\hline & & 0,0190 & 0,0154 & 0,0061 & 0,0068 & 0,1348 & 0,0002 & 0,0209 \\
\hline & & 0,0116 & 217 & 0,0061 & 0,0068 & 0,2035 & 0,0002 & 0,0196 \\
\hline & & 0,0219 & 0,0283 & 0,0061 & 0,0068 & 0,1030 & 0,0003 & \\
\hline
\end{tabular}

\footnotetext{
* Amostras sem duplicata.
} 
TABELA A1 cont. - Concentraçöes em $\mathrm{mg} \mathrm{L}^{-1}$ dos metais nos efluentes quatro colunas lixiviadas.

\begin{tabular}{|c|c|c|c|c|c|c|c|c|}
\hline Amostras (mg L $\left.{ }^{-1}\right)$ & Periodo & $\mathrm{Cr}$ & $\mathrm{Mn}$ & $\mathrm{Ni}$ & $\mathrm{Cu}$ & $\mathrm{Zn}$ & $\mathrm{Cd}$ & $\mathrm{Pb}$ \\
\hline \multirow{6}{*}{$\begin{array}{l}3.0 \\
\text { Coluna } \\
\text { Contaminada } \\
\text { Periodo de } 6 \text { meses }\end{array}$} & Junho & 0,0124 & 0,4233 & 0,0119 & 0,0083 & 0,2344 & 0,0032 & 0,0522 \\
\hline & Julho & 0,0187 & 21,8400 & 0,0223 & 0,0101 & 4,2180 & 0,0066 & 0,1162 \\
\hline & Agosto & 0,0320 & 102,7000 & 0,0886 & 0,0301 & 112,3000 & 0,0186 & 0,2593 \\
\hline & Setembro & 0,0275 & 142,8000 & 0.1525 & 0,0291 & 323,2 & 0,0184 & 0,2728 \\
\hline & Outubro & 0,0126 & 49,9900 & 0,0822 & 0,0092 & 181,4000 & 0,0074 & 0,1244 \\
\hline & Novembro & 0,0170 & 34,1600 & 0,0742 & 0,0083 & 183,6000 & 0,0067 & 0,0950 \\
\hline & & & & & & & & \\
\hline \multirow{12}{*}{$\begin{array}{l}4 .^{\circ} \\
\text { Coluna contaminada } \\
\text { Período de um ano. }\end{array}$} & Junho & 0,0149 & 4,1120 & 0,0304 & 0,0185 & 11,6600 & 0,0050 & 0,1010 \\
\hline & Julho & 0,0192 & 3,9200 & 0,0284 & 0,0196 & 7,5600 & 0,0074 & 0,1097 \\
\hline & Agosto & 0,0288 & 5,6300 & 0,0322 & 0,0272 & 8,3500 & 0,0079 & 0,1684 \\
\hline & Setembro & 0,0353 & 12,5200 & 0,0418 & 0,0413 & 16,2700 & 0,0107 & 0,2345 \\
\hline & Outubro & 0,0383 & 12,5800 & 0,0418 & 0,0373 & 16,3100 & 0,0103 & 0,2266 \\
\hline & Novembro & 0,0265 & 15,3800 & 0,0650 & 0,0224 & 36,3300 & 0,0093 & 0,1702 \\
\hline & Dezembro & 0,0221 & 15,2400 & 0,0676 & 0,0176 & 43,2300 & 0,0078 & 0,1287 \\
\hline & Janeiro & 0,0167 & 13,6000 & 0.1245 & 0,0131 & 54,6000 & 0,0065 & 0,1062 \\
\hline & Fevereiro & 0,0147 & 4,1480 & 0,0564 & 0,0068 & 20,8600 & 0,0010 & 0,0289 \\
\hline & Março & 0,0166 & 4,5580 & 0,0647 & 0,0068 & 22,4900 & 0,0003 & 0,0309 \\
\hline & Abril & 0.0270 & 4,5990 & 0,0585 & 0,0068 & 22,0300 & 0,0006 & 0,0399 \\
\hline & Maio & 0,0225 & 4,1500 & 0,0571 & 0,0068 & 20,1400 & 0,0009 & 0,0390 \\
\hline
\end{tabular}




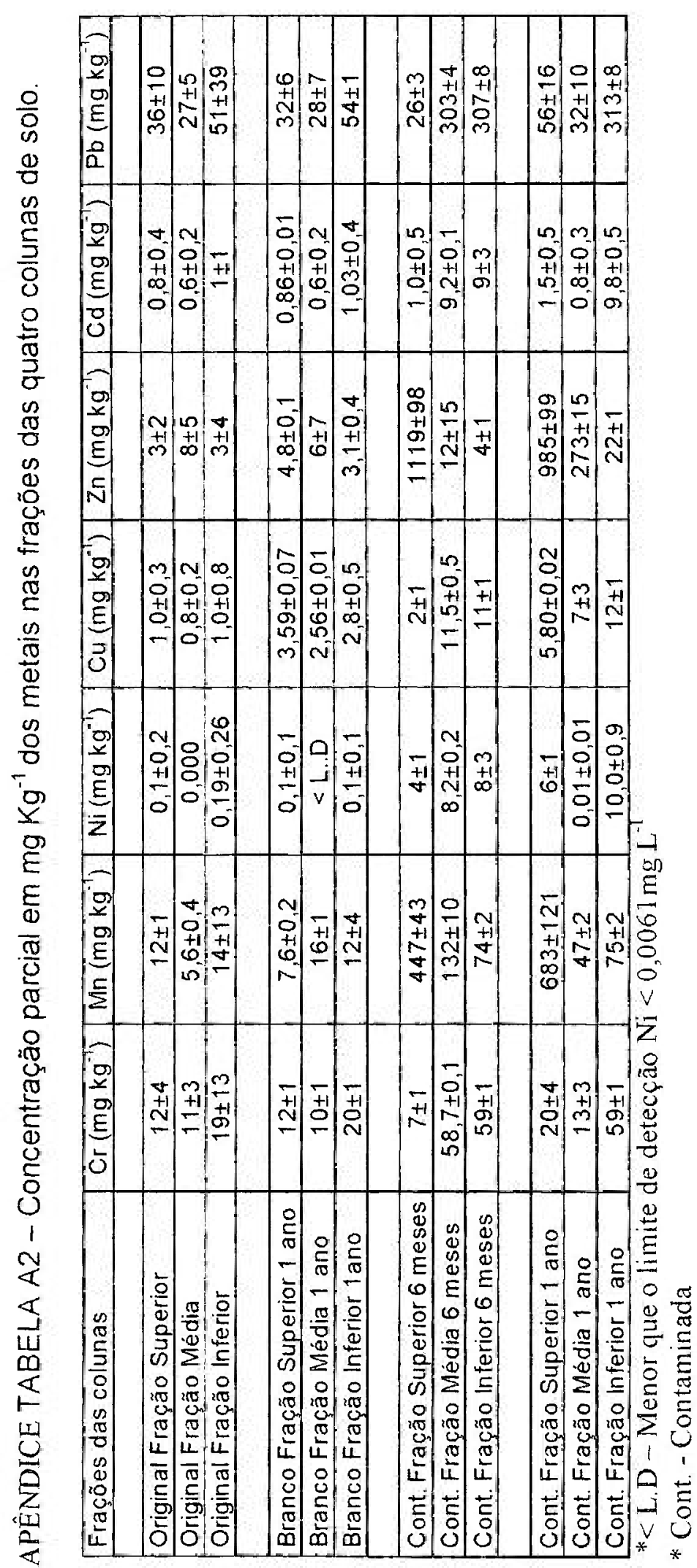




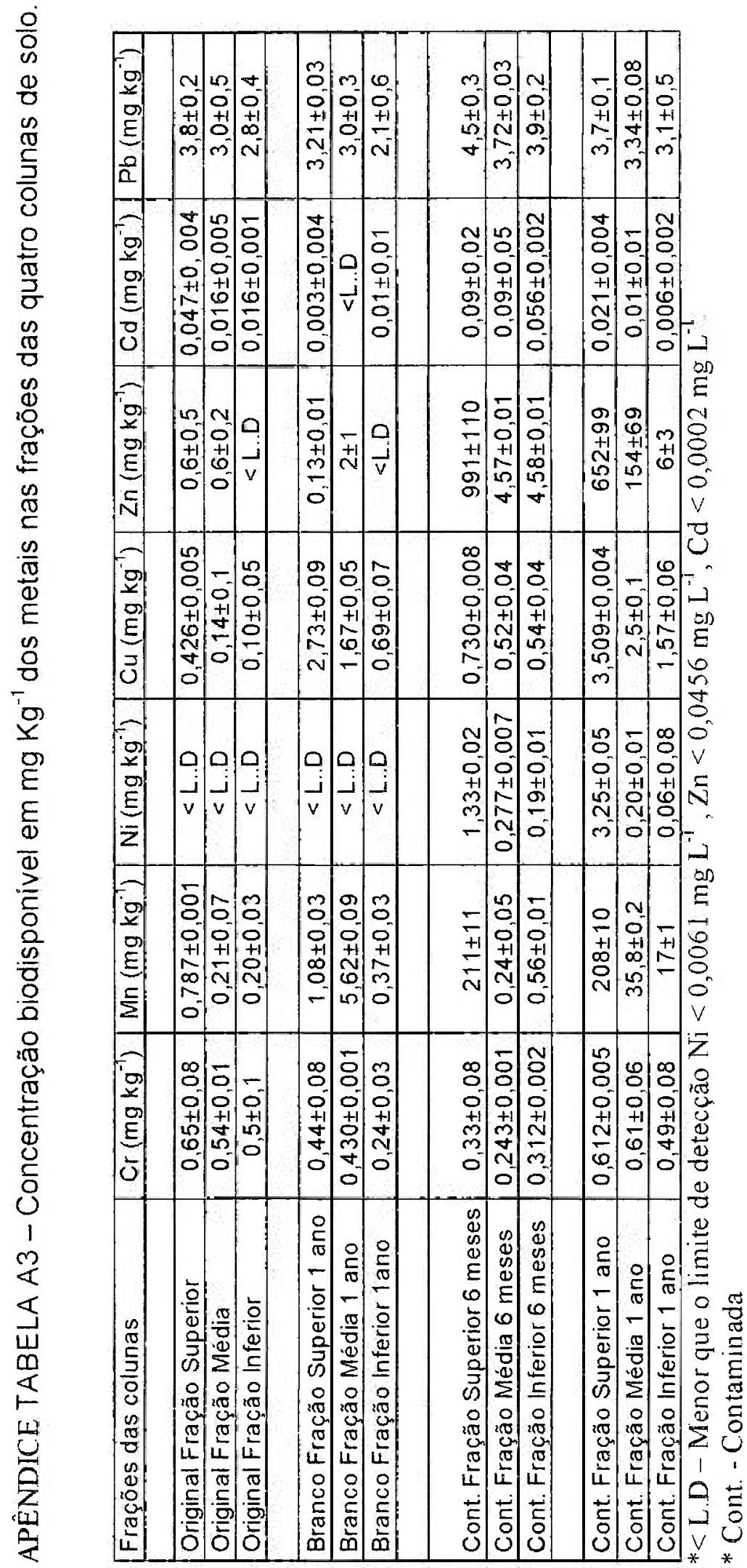




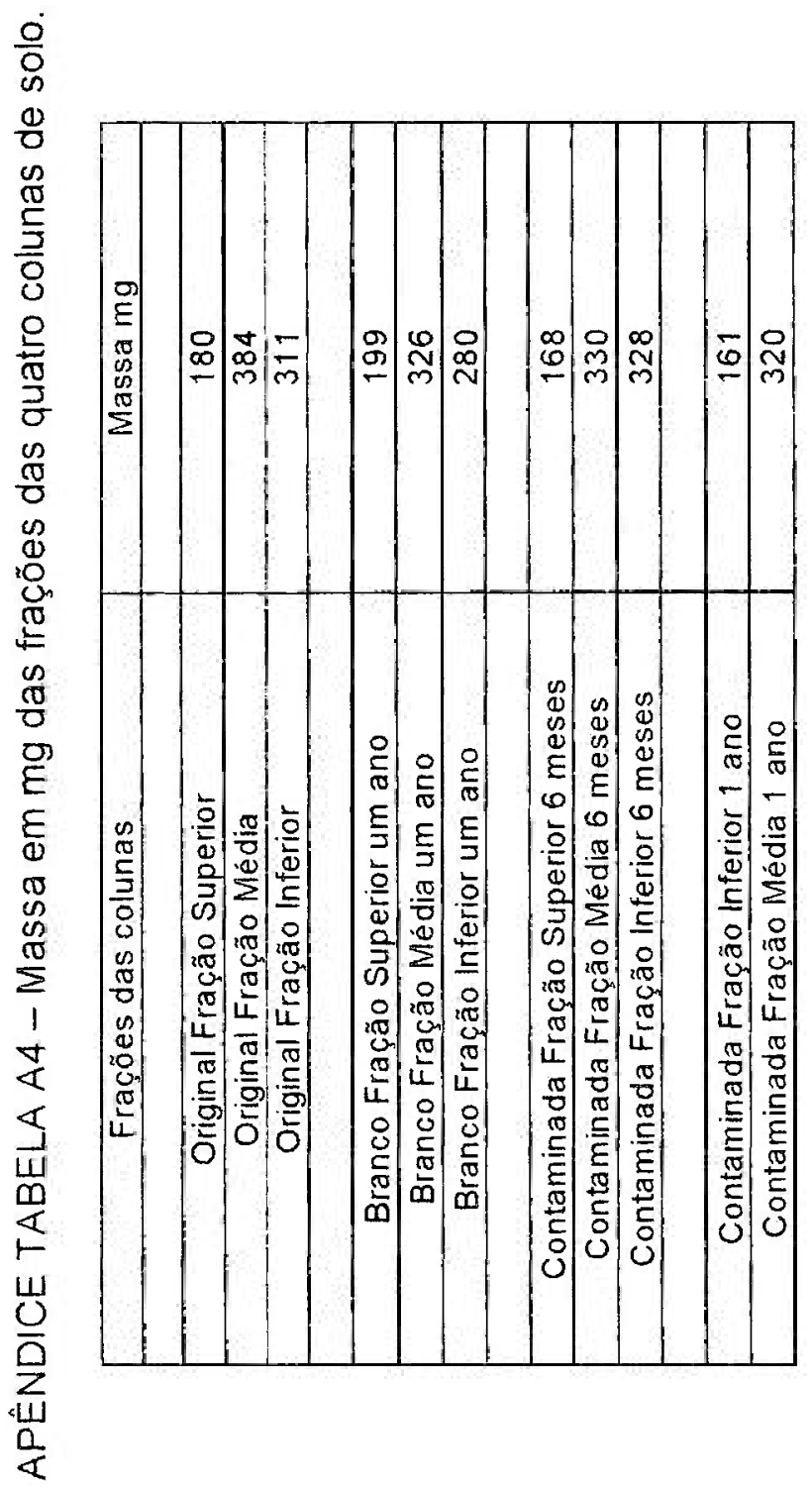

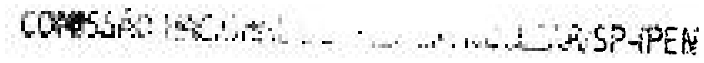

